\title{
Activities of the Water Resources Division in Arizona, 1986-91
}

Compiled by LAURA M. SPICER and ELLEN K. VAN DE VANTER

U.S. GEOLOGICAL SURVEY

Open-File Report 93-165

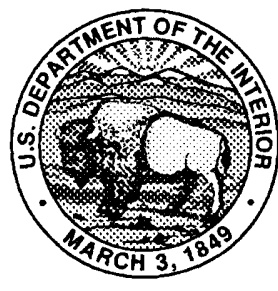




\section{U.S. DEPARTMENT OF THE INTERIOR BRUCE BABBITT, Secretary}

U.S. GEOLOGICAL SURVEY

Robert M. Hirsch, Acting Director

For additional information write to:

District Chief

U.S. Geological Survey Water Resources Division 375 South Euclid Avenue Tucson, Arizona 85719
Copies of this report can be purchased from:

U.S. Geological Survey Earth Science Information Center Open-File Reports Section Box 25286, MS 517

Denver Federal Center

Denver, CO 80225 


\section{MESSAGE FROM THE ARIZONA DISTRICT CHIEF}

A century of activity and publication of more than 860 water-resources related reports for the State of Arizona demonstrate an historical role for the U.S. Geological Survey in the hydrologic community. These reports continue to serve as the foundation of hydrologic knowledge for the State. Additionally, hydrologic historians will note (1) the evolution and sophistication of the investigative and interpretive tools used to collect and transfer hydrologic data knowledge to the water-user community and (2) a strong and steadfast nonregulatory stance in the midst of highly controversial and political issues. The justification for this stance is simple - the need has existed and will continue to exist for an unbiased entity such as the U.S. Geological Survey to produce credible scientific information.

Major national water issues for the Water Resources Division during fiscal years 1986-91 correspond well to water issues in the State of Arizona. These issues are (1) water availability and competition for this water, (2) quality of water, and (3) management of water and land resources. Studies being conducted by the U.S. Geological Survey and described in this publication are, for the most part, in support of providing data and interpretation to address these issues.

As an agency, we are aware of and dedicated to the premise that credible data are obtained only when subjected to consistent, discipline-related, quality-assurance programs. Throughout the Water Resources Division, continuous quality-assurance programs are conducted for all the activities that influence and ensure the quality of our products and services.

Relevant and complex studies conducted by the Arizona District include radionuclide contamination in the Puerco River basin and migration of acid mine drainage in the Pinal Creek basin in central Arizona. In the lower Colorado River basin, a new method of estimating and distributing consumptive uses of Colorado River water for each user has been developed and work is underway to refine and improve the new method.

Looking to the future, the Arizona District is seeking opportunities to develop a means of quickly and economically tracking changes in the quantities of ground water in storage. The use of sensitive gravity meters has shown great promise and when developed could greatly reduce the cost and time of using water-level measurements in individual wells. In a situation where "safe yield" is a management objective, this new method could be a valuable tool. With regard to ground-water contamination, we are seeking opportunities to evaluate the effectiveness of developing technologies in bio-remediation. The present use of "pump and treat" is proving extraordinarily expensive and of limited effectiveness. Another topic of interest is in monitoring and simulation modeling of land subsidence resulting from ground-water withdrawals. In areas where subsidence has been significant, the effects on the operation and integrity of water distribution and drainage systems have been substantial and expensive. Predictive capability in areas of land subsidence would provide a new dimension in planning and in mitigation.

Robert D. Mac Nish

District Chief

U.S. Geological Survey

Tucson, Arizona 


\section{CONTENTS}

Page

MESSAGE FROM THE ARIZONA DISTRICT CHIEF

iii

ORIGIN OF THE U.S. GEOLOGICAL SURVEY

BASIC MISSION AND PROGRAM OF THE WATER RESOURCES DIVISION........

ARIZONA DISTRICT

Organization.

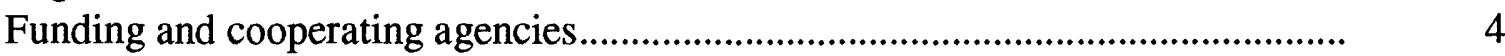

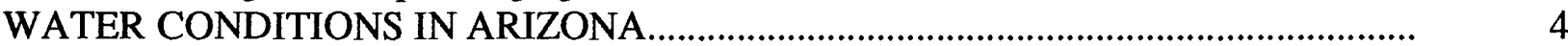

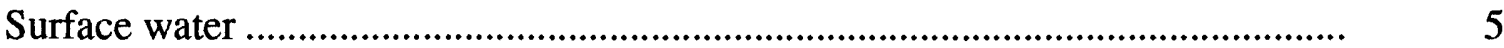

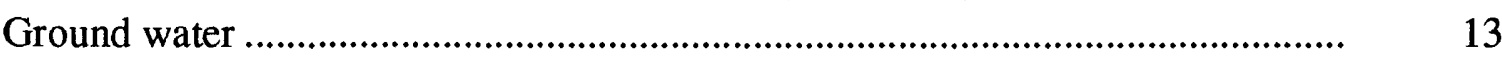

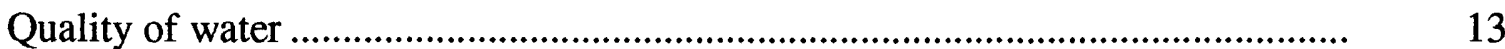

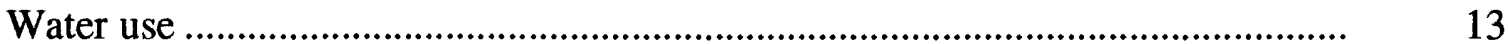

PROJECTS FUNDED IN FISCAL YEARS 1986-91 .................................................. 17

Surface-water stations (AZ001) .................................................................. 19

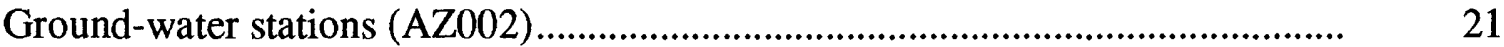

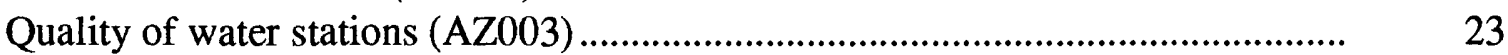

Sediment stations (AZ004) ....................................................................... 25

Studies for Federal Insurance Administration, Department of

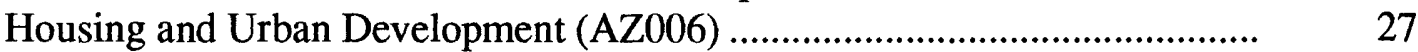

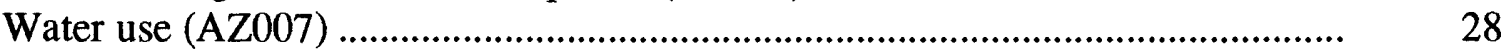

Special site studies for other Federal agencies (AZ023) ............................................................................... $\quad 30$

Reconnaissance study of water supply of Lake

Mead National Recreation Area (AZ024)

Monitoring hydrologic effects of ground-water withdrawals and strip mining at Black Mesa (AZ028 and AZ080)

Land subsidence and earth fissures along the proposed

Salt-Gila and Tucson aqueducts, Maricopa, Pinal,

and Pima Counties, Arizona (AZ047)....

Southwest Alluvial Basins, Regional Aquifer-Systems Appraisal (AZ051)

Monitoring land subsidence and determining earth

fissuring potential in the Tucson basin, Pima County,

Arizona (AZ053)

Arizona water use, Maricopa (AZ067)

Urban rainfall-runoff and runoff modeling in an arid climate,

Tucson metropolitan area, Pima County,

Arizona (AZ069)

Hydrologic Investigation of the Gila River Indian

Reservation (AZ072). 


\section{CONTENTS}

Page

\section{PROJECTS FUNDED IN FISCAL YEARS 1986-91-Continued}

Effects of vegetation conversion on runoff and sediment yields in the East Fork Sycamore Creek drainage basin (AZ073)

Hydrologic effects of Glen Canyon Dam operations on the

Colorado River between Glen Canyon Dam and Hoover

Dam, Arizona (AZ075)

Hydrogeology of basin-fill deposits in western Salt River Valley,

Maricopa County, Arizona (AZ076)

Movement of contaminants in ground water, lower

Miami Wash and Pinal Creek basins, Arizona

(AZ081 and AZ082)

Development of an accounting system for water and consumptive use in the lower Colorado River,

Lake Mead to Mexico (AZ085)

Development of techniques for the prediction of land subsidence due to ground-water withdrawal (AZ086).

Reconnaissance investigations of the hydrologic system in the

San Bernardino Valley, southeast Arizona (AZ088)

Hydrology of the Salt River Indian Reservation (AZ089)

Evaluation of recharge along the Gila River as a result of the October 1983 flood (AZ090)

Lyman Lake water budget (AZ092)

Estimation of salinity loads, Colorado River from Imperial

Dam to southerly international boundary (AZ093)

Stability of alluvial sand bars, Colorado River in

Grand Canyon National Park (AZ095).

Moisture and solute movement in the unsaturated zone in

response to natural and artificial recharge (AZ096)

Irrigation drainage quality in the lower Colorado

River Valley (AZ097)

Geochemistry of ground water in southwest alluvial basins (AZ098)

Basin characteristics and streamflow statistics in Arizona as of 1989 (AZ099)

Flood hazards of distributary-flow areas in southwestern

Arizona (AZ100)

Contaminants in runoff, greater Tucson area (AZ101).

Predictive accuracy of ground-water models (AZ103). 


\section{CONTENTS}

Page

PROJECTS FUNDED IN FISCAL YEARS 1986-91-Continued

Occurrence and movement of radionuclides and other trace elements in the Puerco and lower Little Colorado River

basins, Arizona and New Mexico (AZ104 and AZ110).

Trend analysis of selected water-quality data at stream gages in the Verde River basin (AZ105)

Flood frequency and erosion potential in ephemeral stream channels - a case study of the Santa Cruz River (AZ107)

Prediction procedures for ungaged arid watersheds in the southwestern United States (AZ108)

Paleoflood data-precision of discharge estimates and accuracy of estimated recurrence interval (AZ109)

Mapping vegetation water use calculated from remotely sensed data as a function of soil moisture (AZ111)

Water resources appraisal, San Carlos Indian Reservation (AZ112)

Avra Valley inverse modeling and error analysis study (AZ113)...

National Water Information System (NWIS) program-

PRIME-based NWIS ground-water site inventory

subsystem maintenance (AZ114)

Spatial and temporal variability of point micrometeorological data used to estimate regional evapotranspiration

(AZ115)

Trend analysis of water-quality data at stream gages in the

Gila River basin (AZ116)

Grand Canyon hydrologic data and data-base management (AZ117)

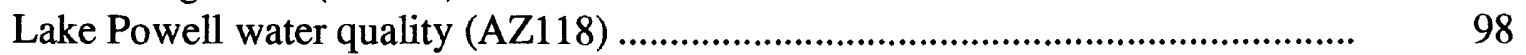

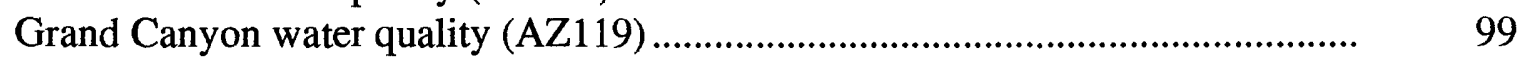

Grand Canyon beach evolution (AZ120) .......................................................... 100

Grand Canyon sediment transport (AZ121) .................................................. 102

Accounting for diversions of Colorado River water drawn

from the main stream by underground pumping in the

lower Colorado River basin (AZ122).

Hydrologic investigation of Montezuma Well and surrounding area (AZ123)

Extent and nature of flood hazards in distributary-flow areas in Maricopa County, Arizona (AZ124) 


\section{CONTENTS}

Page

PROJECTS FUNDED IN FISCAL YEARS 1986-91-Continued

Solute balance and geochemical interactions, Roosevelt

Lake, Arizona (AZ125).

Signature and mapping of nitrates in ground

water in West Salt River Valley (AZ126)

Flood-model assessment and water-quality characterization of urban runoff, Maricopa County, Arizona (AZ127)

Investigation of sediment transport in ephemeral rivers of Maricopa County, Arizona (AZ128)

Geochemical investigation in and near abandoned uranium mines, Cameron and Monument Valley mining districts (AZ129)

Investigation of isotope hydrology of Upper Verde headwaters (AZ130)

Collection and analysis of ground-water samples from four monitor wells at Davis-Monthan Air Force Base, Tucson, Arizona (AZ131)

BIBLIOGRAPHY-REPORTS FOR ARIZONA PUBLISHED IN 


\section{FIGURES}

Figure 1. Chart showing organization of the Arizona District, 1991 ....................... 3

2. Graph showing source of Arizona District funds in fiscal years 1986-91

3. Graph showing categories of investigations in the Arizona

District by funding, fiscal years 1986-91

4. Map showing water provinces of Arizona

5. Map showing streamflow-gaging stations, water year 1990

6. Schematic diagram showing streamflow-gaging stations and surface-water-quality stations on streams, diversions, and return flows between Imperial

Dam and the southerly international boundary

7. Map showing partial-record streamflow-gaging stations, water year 1990

8. Graph showing runoff during water year 1990 compared with median runoff for water years $1951-80$ for three representative streamflow-gaging stations

9. Hydrographs showing water level in selected wells in the Basin and Range lowlands province

10. Map showing surface-water-quality sites, water year 1990

\section{TABLES}

Table 1. Sources of funding in the Arizona District, fiscal years 1986-91

2. Distribution of data, investigations, and research funding by source for the Arizona District, fiscal years 1986-91 
Multiply

inch (in.)

foot (ft)

mile (mi)

acre

square mile $\left(\mathrm{mi}^{2}\right)$

acre-foot (acre-ft)

cubic foot per second $\left(\mathrm{ft}^{3} / \mathrm{s}\right.$

gallon per minute (gal $/ \mathrm{min})$

million gallons per day

(Mgal/d)
By

25.4

0.3048

1.609

4,047

2.590

0.001233

0.02832

0.06308

0.04381
To obtain

millimeter

meter

kilometer

square meter

square kilometer cubic hectometer cubic meter per second liter per second cubic meter per second

Fiscal Year and Water Year: Both comprise the 12-month period from October 1 through September 30 and are designated by the year in which that period ends (for example, Fiscal Year 1986 began October 1, 1985, and ended September 30, 1986).

Trade Names: The use of trade names in this report is for identification purposes only and does not constitute endorsement by the U.S. Geological Survey. 


\section{ORIGIN OF THE U.S. GEOLOGICAL SURVEY}

The U.S. Geological Survey (USGS) was established by an act of Congress on March 3, 1879, to provide a permanent Federal agency to conduct the systematic and scientific "classification of the public lands, and examination of the geological structure, mineral resources, and products of national domain." An integral part of that original mission includes publishing and disseminating the earth-science information needed to understand, to plan the use of, and to manage the Nation's energy, land, mineral, and water resources.

Since 1879, the research and fact-finding role of the USGS has grown and been modified to meet the changing needs of the Nation it serves. As part of that evolution, the USGS has become the Federal Government's largest earth-science research agency, the Nation's largest civilian mapmaking agency, the primary source of data on the Nation's surface- and ground-water resources, and the employer of the largest number of professional earth scientists. Today's programs serve a diversity of needs and users. Programs include:

- Conducting detailed assessments of the energy and mineral potential of the Nation's land and offshore areas.

- Investigating and issuing warnings of earthquakes, volcanic eruptions, landslides, and other geologic and hydrologic hazards.

- Conducting research on the geologic structure of the Nation.

- Studying the geologic features, structure, processes, and history of the other planets of our solar system.

- Conducting topographic surveys of the Nation and preparing topographic and thematic maps and related cartographic products.

- Developing and producing digital cartographic data bases and products.

- Collecting data on a routine basis to determine the quantity, quality, and use of surface and ground water.

- Conducting water-resource appraisals in order to describe the consequences of alternative plans for developing land and water resources.

- Conducting research in hydraulics and hydrology and coordinating all Federal water-data acquisition.

- Using remotely sensed data to develop new cartographic, geologic, and hydrologic research techniques for natural-resources planning and management.

- Providing earth-science information through an extensive publications program and a network of public-access points.

Along with its continuing commitment to meet the growing and changing earth-science needs of the Nation, the USGS remains dedicated to its original mission to collect, analyze, interpret, publish, and disseminate information about the natural resources of the Nationproviding "Earth science in the public service." 


\section{BASIC MISSION AND PROGRAM OF THE WATER RESOURCES DIVISION}

The mission of the Water Resources Division, which supports the overall mission of the U.S. Department of the Interior and the Geological Survey, is to provide the hydrologic information and understanding needed for the best use and management of the Nation's water resources for the benefit of the people of the United States.

The mission of the Division is accomplished through programs supported by the U.S. Geological Survey independent of, or in cooperation with, other Federal and non-Federal agencies. These programs include the following:

- Collecting, on a systematic basis, data needed for the continuing determination and evaluation of the quantity, quality, and use of the Nation's water resources.

- Conducting analytical and interpretive water-resource appraisals of the occurrence, availability, and the physical, chemical, and biological characteristics of surface water and ground water.

- Conducting basic problem-oriented research in hydrology to improve the scientific basis for investigations and measurement techniques, and to predict quantitatively the response of hydrologic systems to stress.

- Disseminating water data and the results of investigations and research through reports, maps, computerized information services, and other forms of public releases.

- Coordinating the activities of Federal agencies in the acquisition of water data for streams, lakes, reservoirs, estuaries, and ground water.

- Providing scientific and technical assistance in hydrology to other Federal, State, and local agencies; to licensees of the Federal Power Commission; and to international agencies on behalf of the Department of State.

\section{ARIZONA DISTRICT}

Water-resources activities of the U.S. Geological Survey in Arizona consist of collecting water-resources data and conducting interpretive hydrologic investigations and research. The water-resources data and the results of the interpretive investigations and research are published or released by the U.S. Geological Survey or by cooperating agencies. This report describes the datacollection activities and water-resources investigations in Arizona for fiscal years 1986-91 (October 1, 1985, to September 30, 1991). Reports published from 1984 to 1991 are included in the back of this report to provide a complete list since the last activities report, which included reports published through 1983. 


\section{Organization}

The Arizona District, which is headquartered in Tucson, is under the direction of the District Chief, Robert D. Mac Nish. Hydrologic investigations and data-collection activities are conducted from project offices in Tucson, Tempe, and Flagstaff and field offices in Flagstaff, Tempe, Tucson, and Yuma. At the end of fiscal year 1991, the Arizona District employed a total of 125 persons (101 full time and 24 other than full time)-16 in Flagstaff, 25 in Tempe, 76 in Tucson, and 8 in Yuma. The organization of the Arizona District is shown in figure 1. Inquiries regarding projects described in this report may be directed to one of the following offices:

Arizona District Office 375 South Euclid Avenue Tucson, Arizona 85719 $602670-6671$
Tempe Field Office

1545 West University Drive

Tempe, Arizona 85281

602 379-3086
Flagstaff Field Office

2255 North Gemini Drive

Flagstaff, Arizona 86001

$602556-7136$
Yuma Field Office 1940 South Third Avenue Yuma, Arizona 86001 $602782-6024$

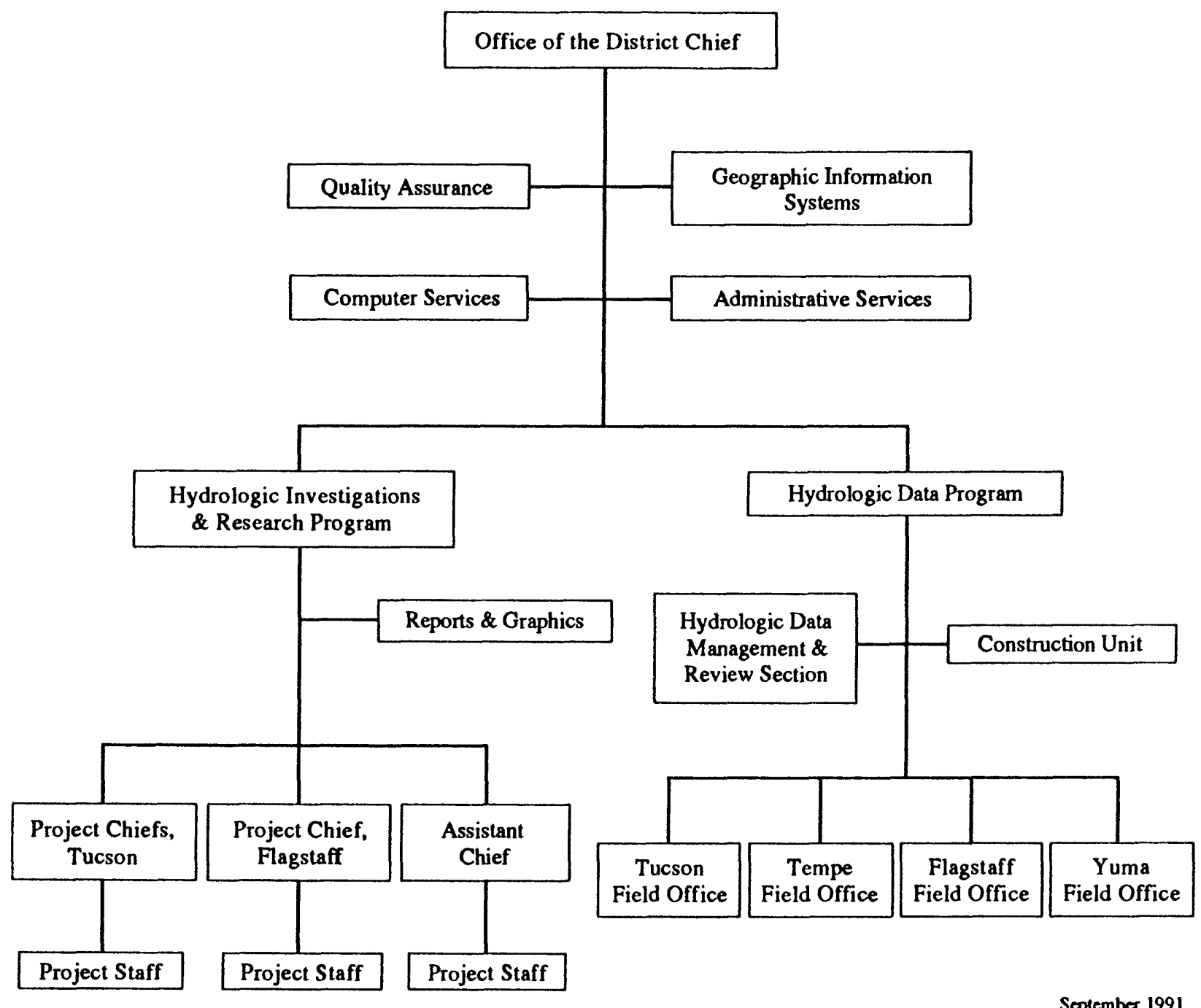

Figure 1. Organization of the Arizona District, 1991. 


\section{Funding and Cooperating Agencies}

In fiscal years 1986-1991, State, local, and Federal agencies contributed funds and (or) services in cooperative programs with the Arizona District (figs. 2 and 3; tables 1 and 2). Agencies that supported water-resources investigations through cooperative agreements are listed below:

\section{Local and State Agencies}

Arizona Department of Environmental Quality

Arizona Department of Health Services

Arizona Department of Water Resources

Arizona Municipal Water Users' Association

Arizona State Land Department

City of Safford

City of Scottsdale

City of Tucson

Colorado Department of Highways

Flood Control District of Maricopa County

Gila Valley Irrigation District

Maricopa County Municipal Water

Conservation District No. 1

The Navajo Nation

Metropolitan Water District of Southern

California

New Mexico Environmental Department

Pima County Board of Supervisors

Salt River Valley Water Users' Association

San Carlos Irrigation and Drainage District

Show Low Irrigation Company

\section{Federal Agencies}

Federal Emergency Management Agency

Federal Energy Resource Commission (Arizona Public Service and Phelps Dodge Corporation)

National Aeronautics and Space Administration

Office of Navajo and Hopi Indian Relocation

U.S. Department of Agriculture Forest Service

U.S. Department of the Interior Bureau of Indian Affairs Bureau of Land Management Bureau of Reclamation Fish and Wildlife Service National Park Service Office of the Secretary Office of Surface Mining

U.S. Department of Defense Corps of Engineers

U.S. Department of Energy

U.S. Environmental Protection Agency

\section{WATER CONDITIONS IN ARIZONA}

The two major physiographic provinces of the southwestern United States, the Colorado Plateau province and the Basin and Range province, are separated across much of the State by the mountainous region to the south of the Mogollon Rim. The separated physiographic provinces form three distinct water provinces - the Plateau uplands province in the northern part of the State and the Central highlands province and the Basin and Range lowlands province in the southern and southwestern parts of the State (fig. 4). The Plateau uplands water province has many arid rock benches separated by slopes and valleys. Annual precipitation ranges from 10 to 25 inches. The Central highlands water province is bounded on the north by the Mogollon Rim escarpment and 


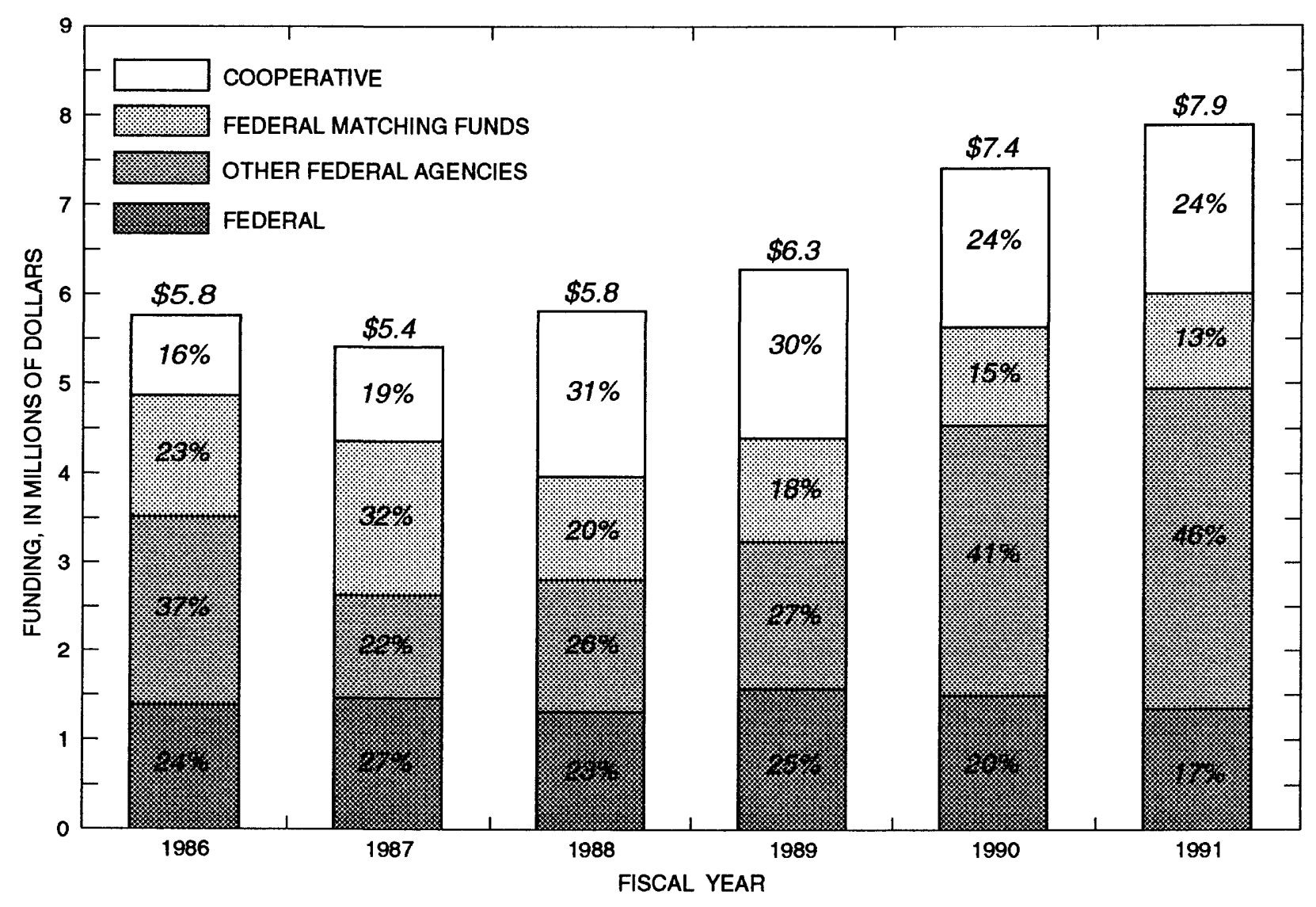

Figure 2. Source of Arizona District funds in fiscal years 1986-91.

consists of rugged mountains. Annual precipitation ranges from about 15 to 30 inches. The Basin and Range lowlands water province is characterized by arid base-level plains separated by steep high mountains. Annual precipitation in the basins ranges from 4 to 12 inches.

\section{Surface Water}

The Colorado River enters Arizona from the north and flows westward and southward to the southwest corner of the State. Nearly all streams in Arizona are tributary to the Colorado, although the quantity of tributary inflow is small because of the intensive use and storage within the State. Major tributaries to the Colorado River that drain large parts of Arizona are the Little Colorado, Bill Williams, and Gila Rivers. A few small streams drain to Mexico. Streamflow data are collected at a network of streamflow-gaging stations (figs. 5, 6, and 7).

Runoff patterns in Arizona vary greatly. In desert areas of the Plateau uplands water province and the Basin and Range lowlands water province, average annual runoff is less than 0.1 inch. In the mountainous parts of these provinces and in most of the Central highlands water province, annual runoff is as much as $\mathbf{5}$ inches. Runoff from perennial streams in the Central 


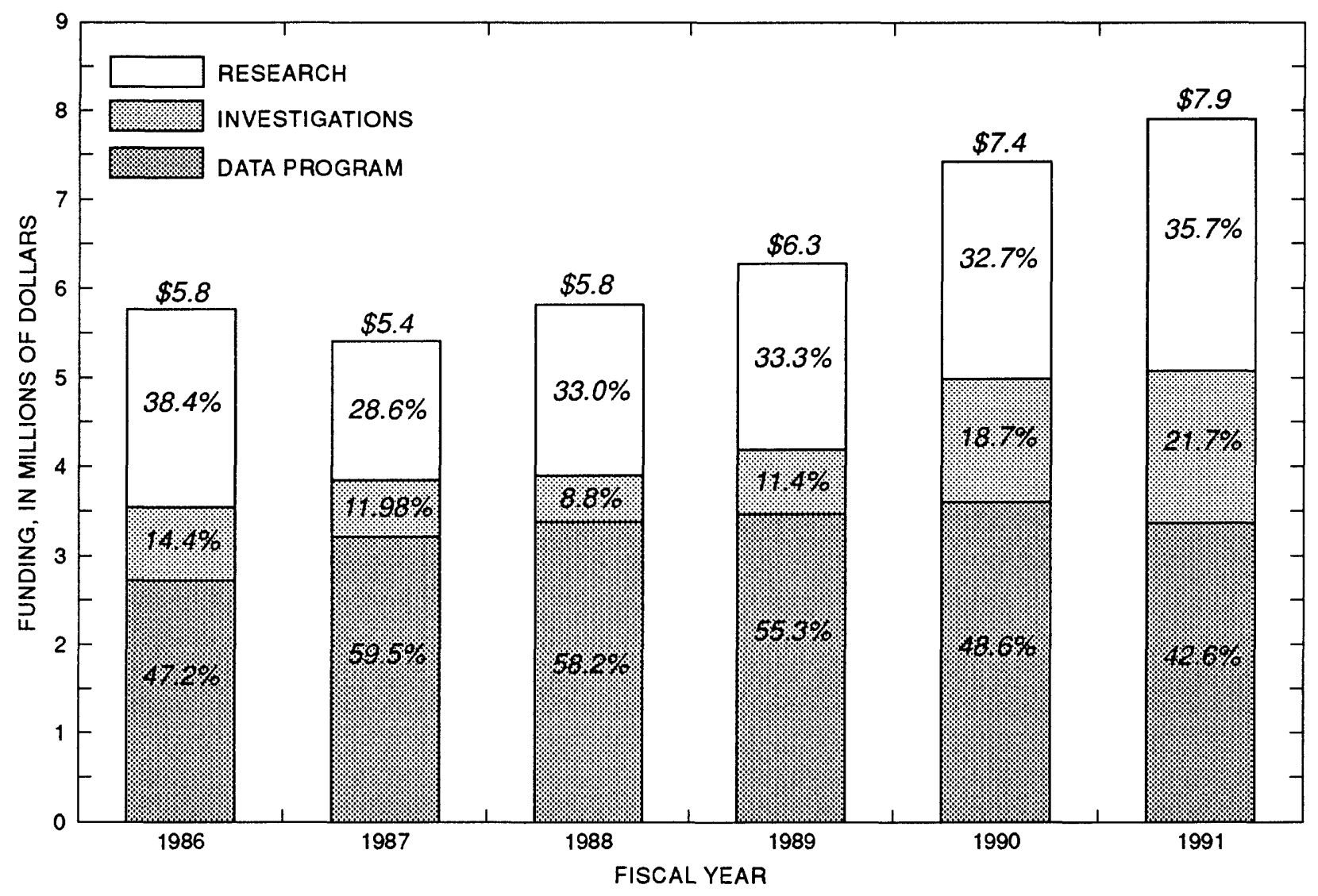

Figure 3. Categories of investigations in the Arizona District by funding, fiscal years 1986-91.

Table 1. Sources of funding in the Arizona District, fiscal years 1986-91

\begin{tabular}{|c|c|c|c|c|c|}
\hline Year & Federal & $\begin{array}{c}\text { Other Federal } \\
\text { Agencies }\end{array}$ & $\begin{array}{l}\text { Federal } \\
\text { matching }\end{array}$ & $\begin{array}{l}\text { Cooperator } \\
\text { matching }\end{array}$ & Total \\
\hline $\begin{array}{l}1986 \ldots \ldots \ldots \ldots . . . . . . . . . \\
\text { Percent of total... }\end{array}$ & $\begin{array}{c}\$ 1,390,850 \\
24\end{array}$ & $\begin{array}{c}\$ 2,134,715 \\
37\end{array}$ & $\begin{array}{c}\$ 1,346,804 \\
23\end{array}$ & $\begin{array}{c}\$ 893,600 \\
16\end{array}$ & $\begin{array}{c}\$ 5,765,969 \\
100\end{array}$ \\
\hline $\begin{array}{l}1987 \ldots \ldots . . . . . . . . \\
\text { Percent of total... }\end{array}$ & $\begin{array}{c}\$ 1,461.585 \\
27\end{array}$ & $\begin{array}{c}\$ 1,168,451 \\
22\end{array}$ & $\begin{array}{c}\$ 1,740,170 \\
32\end{array}$ & $\begin{array}{c}\$ 1,043,120 \\
19\end{array}$ & $\begin{array}{c}\$ 5,413,326 \\
100\end{array}$ \\
\hline $\begin{array}{l}1988 \ldots . . . \ldots . . . . . \\
\text { Percent of total... }\end{array}$ & $\begin{array}{c}\$ 1,315,230 \\
23\end{array}$ & $\begin{array}{c}\$ 1,495,940 \\
26\end{array}$ & $\begin{array}{c}\$ 1,160,030 \\
19\end{array}$ & $\begin{array}{c}\$ 1,847,560 \\
32\end{array}$ & $\begin{array}{c}\$ 5,818,760 \\
100\end{array}$ \\
\hline 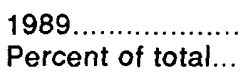 & $\begin{array}{c}\$ 1,570,410 \\
25\end{array}$ & $\begin{array}{c}\$ 1,680,743 \\
27\end{array}$ & $\begin{array}{c}\$ 1,150,000 \\
18\end{array}$ & $\begin{array}{c}\$ 1,880,714 \\
30\end{array}$ & $\begin{array}{c}\$ 6,281,867 \\
100\end{array}$ \\
\hline $\begin{array}{l}1990 \ldots . . . . . . . . . \\
\text { Percent of total... }\end{array}$ & $\begin{array}{c}\$ 1,496,840 \\
20\end{array}$ & $\begin{array}{c}\$ 3,043,988 \\
41\end{array}$ & $\begin{array}{c}\$ 1,100,180 \\
15\end{array}$ & $\begin{array}{c}\$ 1,780,145 \\
24\end{array}$ & $\begin{array}{c}\$ 7,421,153 \\
100\end{array}$ \\
\hline $\begin{array}{l}1991 \ldots \ldots \ldots \ldots \ldots \\
\text { Percent of total... }\end{array}$ & $\begin{array}{c}\$ 1,348,795 \\
17\end{array}$ & $\begin{array}{c}\$ 3,604,688 \\
45\end{array}$ & $\begin{array}{c}\$ 1,056,730 \\
14\end{array}$ & $\begin{array}{c}\$ 1,892,810 \\
24\end{array}$ & $\begin{array}{c}\$ 7,930,023 \\
100\end{array}$ \\
\hline
\end{tabular}


Table 2. Distribution of data, investigations, and research funding by source for the Arizona District, fiscal years 1986-91

\begin{tabular}{|c|c|c|c|c|c|c|c|c|c|c|c|c|}
\hline \multirow[b]{3}{*}{ Source of funding } & \multicolumn{12}{|c|}{ Fiscal Year } \\
\hline & \multicolumn{2}{|c|}{1986} & \multicolumn{2}{|c|}{1987} & \multicolumn{2}{|c|}{1988} & \multicolumn{2}{|c|}{1989} & \multicolumn{2}{|c|}{1990} & \multicolumn{2}{|c|}{1991} \\
\hline & $\begin{array}{l}\text { Funding } \\
(1,000 \mathrm{~s})\end{array}$ & $\begin{array}{l}\text { Percent } \\
\text { of total }\end{array}$ & $\begin{array}{l}\text { Funding } \\
(1,000 s)\end{array}$ & $\begin{array}{l}\text { Percent } \\
\text { of total }\end{array}$ & $\begin{array}{l}\text { Funding } \\
(1,000 \mathrm{~s})\end{array}$ & $\begin{array}{l}\text { Percent } \\
\text { of total }\end{array}$ & $\begin{array}{l}\text { Funding } \\
(1,000 \mathrm{~s})\end{array}$ & $\begin{array}{l}\text { Percent } \\
\text { of total }\end{array}$ & $\begin{array}{l}\text { Funding } \\
(1,000 \mathrm{~s})\end{array}$ & $\begin{array}{l}\text { Percent } \\
\text { of total }\end{array}$ & $\begin{array}{l}\text { Funding } \\
(1,000 \text { s })\end{array}$ & $\begin{array}{l}\text { Percent } \\
\text { of total }\end{array}$ \\
\hline \multicolumn{13}{|l|}{ Data: } \\
\hline $\begin{array}{l}\text { Federal ....................... } \\
\text { Other Federal }\end{array}$ & $\$ 602$ & 22.1 & $\$ 664$ & 20.7 & $\$ 663$ & 19.6 & $\$ 717$ & 20.6 & $\$ 776$ & 21.5 & $\$ 670$ & 19.9 \\
\hline Agencies....... & 502 & 18.5 & 635 & 19.7 & 699 & 20.6 & 469 & 13.5 & 528 & 14.7 & 524 & 15.6 \\
\hline Federal matching.......... & 616 & 22.6 & 651 & 20.2 & 710 & 21.0 & 818 & 23.5 & 841 & 23.3 & 817 & 24.3 \\
\hline Cooperator matching.... & 1,001 & 36.8 & 1,267 & 39.4 & 1,313 & 38.8 & 1,471 & 42.4 & 1,459 & 40.5 & 1,355 & 40.2 \\
\hline 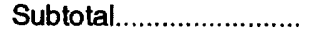 & $\$ 2,721$ & 100.0 & $\$ 3,217$ & 100.0 & $\$ 3,385$ & 100.0 & $\$ 3,475$ & 100.0 & $\$ 3,604$ & 100.0 & $\$ 3,366$ & 100.0 \\
\hline \multicolumn{13}{|l|}{ investigations: } \\
\hline $\begin{array}{l}\text { Federal........................ } \\
\text { Other Federal }\end{array}$ & $\$ 5$ & 0.6 & $\$-$ & 0.6 & $\$-$ & - & $\$ 36$ & 5.0 & $\$ 41$ & 2.9 & $\$ 59$ & 3.4 \\
\hline Agencies...................... & 555 & 67.0 & 206 & 32.4 & 156 & 30.3 & 223 & 31.2 & 918 & 66.2 & 1,000 & 56.3 \\
\hline Federal matching.......... & 107 & 12.9 & 177 & 27.8 & 176 & 34.2 & 208 & 29.1 & 215 & 15.5 & 202 & 11.8 \\
\hline Cooperator matching.... & 161 & 19.5 & 253 & 39.8 & 163 & 35.5 & 248 & 34.7 & 215 & 15.5 & 453 & 26.4 \\
\hline 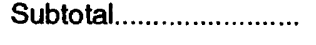 & $\$ 828$ & 100.0 & $\$ 636$ & 100.0 & $\$ 515$ & 100.0 & $\$ 715$ & 100.0 & $\$ 1,389$ & 100.0 & $\$ 1,714$ & 100.0 \\
\hline \multicolumn{13}{|l|}{ Research: } \\
\hline $\begin{array}{l}\text { Federal.......................... } \\
\text { Other Federal }\end{array}$ & $\$ 784$ & 35.4 & $\$ 798$ & 51.1 & $\$ 651$ & 33.9 & $\$ 817$ & 39.1 & $\$ 680.0$ & 28.0 & $\$ 620$ & 22.0 \\
\hline Agencies....................... & 1,078 & 48.6 & 328 & 21.0 & 640 & 33.4 & 989 & 47.3 & 1599.0 & 65.8 & 2080 & 73.7 \\
\hline Federal matching .......... & 170 & 7.7 & 215 & 13.8 & 275 & 14.3 & 124 & 5.9 & 44.5 & 1.8 & 37 & 1.3 \\
\hline Cooperator matching.... & 185 & 8.3 & 220 & 14.1 & 352 & 18.4 & 162 & 7.7 & 106.5 & 4.4 & 85 & 3.0 \\
\hline 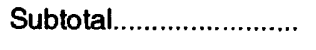 & $\$ 2,217$ & 100.0 & $\$ 1,561$ & 100.0 & $\$ 1,918$ & 100.0 & $\$ 2,092$ & 100.0 & $\$ 2,430.0$ & 100.0 & $\$ 2,822$ & 100.0 \\
\hline Total ....................... & $\$ 5,766$ & --- & $\$ 5,413$ & -- & $\$ 5,819$ & -- & $\$ 6,282$ & - & $\$ 7,421$ & - & $\$ 7,903$ & $\cdots$ \\
\hline
\end{tabular}

highlands is collected in storage reservoirs that provide water for use in the Basin and Range lowlands. Some runoff infiltrates and recharges the ground-water reservoirs. The quantity of monthly runoff for water year 1990 compared with median monthly runoff for water years 1951 80 for three representative gaging stations is shown in figure 8.

Except for the Colorado River, few streams in the Plateau uplands water province are perennial. In the Central highlands water province, the principal stream is the Gila River, which has its headwaters in New Mexico. The Salt, Verde, and Aqua Fria Rivers originate in the Central highlands and are important tributaries to the Gila River. In the deserts of the Basin and Range lowlands water province, few streams are perennial. Major agricultural areas and the homes of seven of every eight Arizonans are in this province; the economy depends on ground water and water from surface storage reservoirs. Three reservoirs in the Basin and Range lowlands are provided with runoff from perennial streams in the Central highlands. 


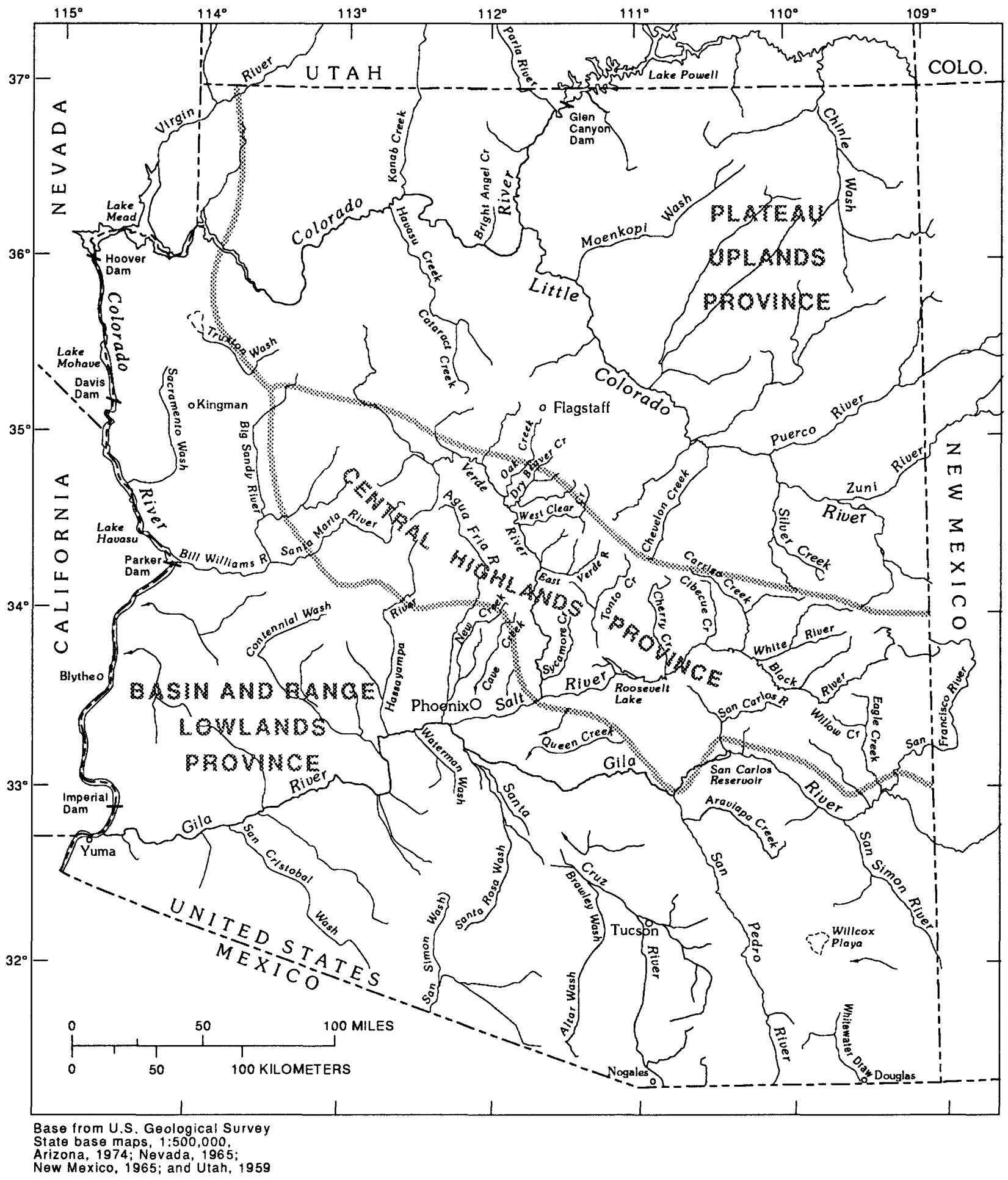

EXPLANATION

BOUNDARY OF WATER PROVINCE

Figure 4. Water provinces of Arizona. 


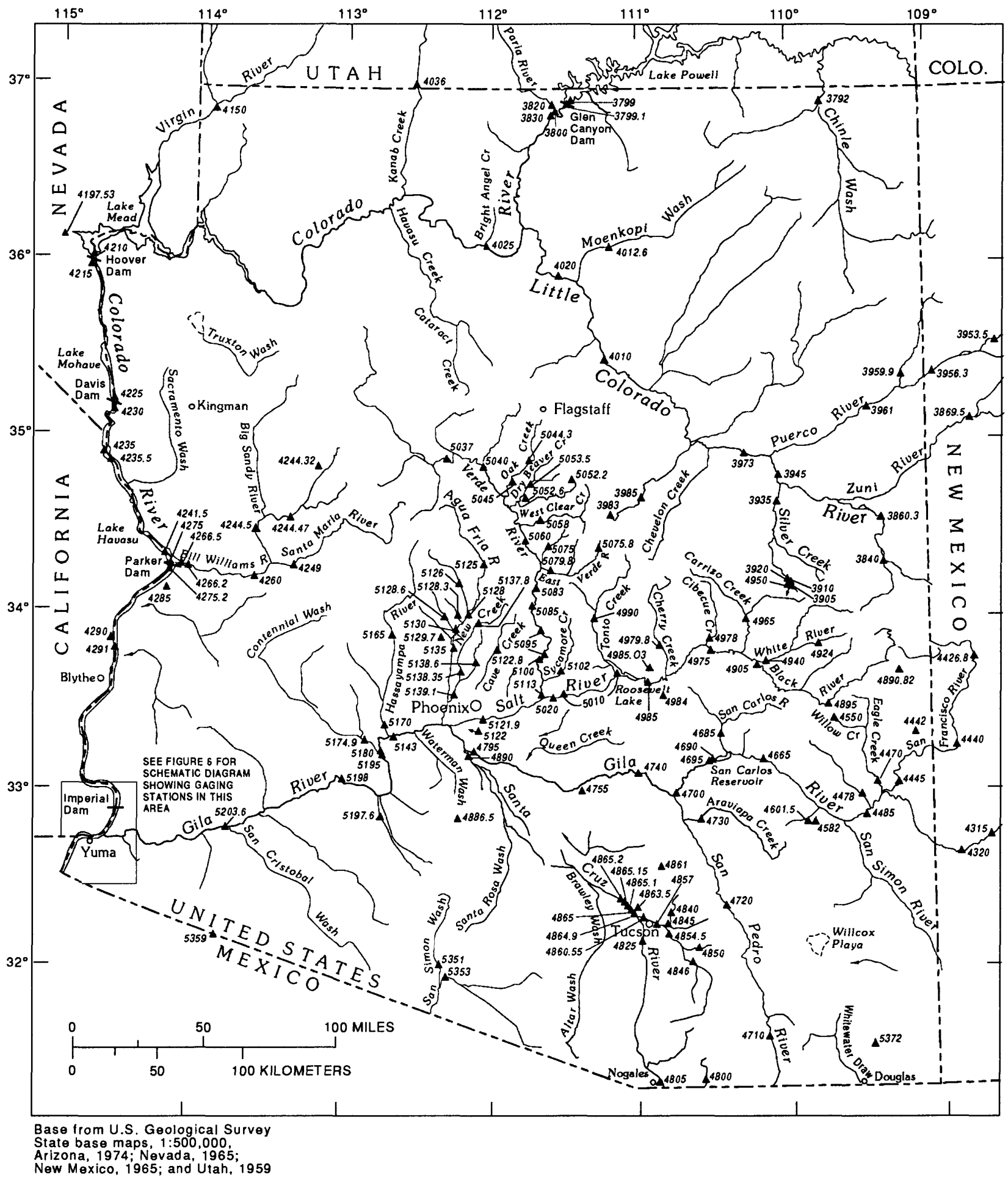

EXPLANATION

$\triangle 4665$ STREAMFLOW-GAGING STATION AND

ABBREVIATED NUMBER-Complete

station number is 09466500

Figure 5. Streamflow-gaging stations, water year 1990. 


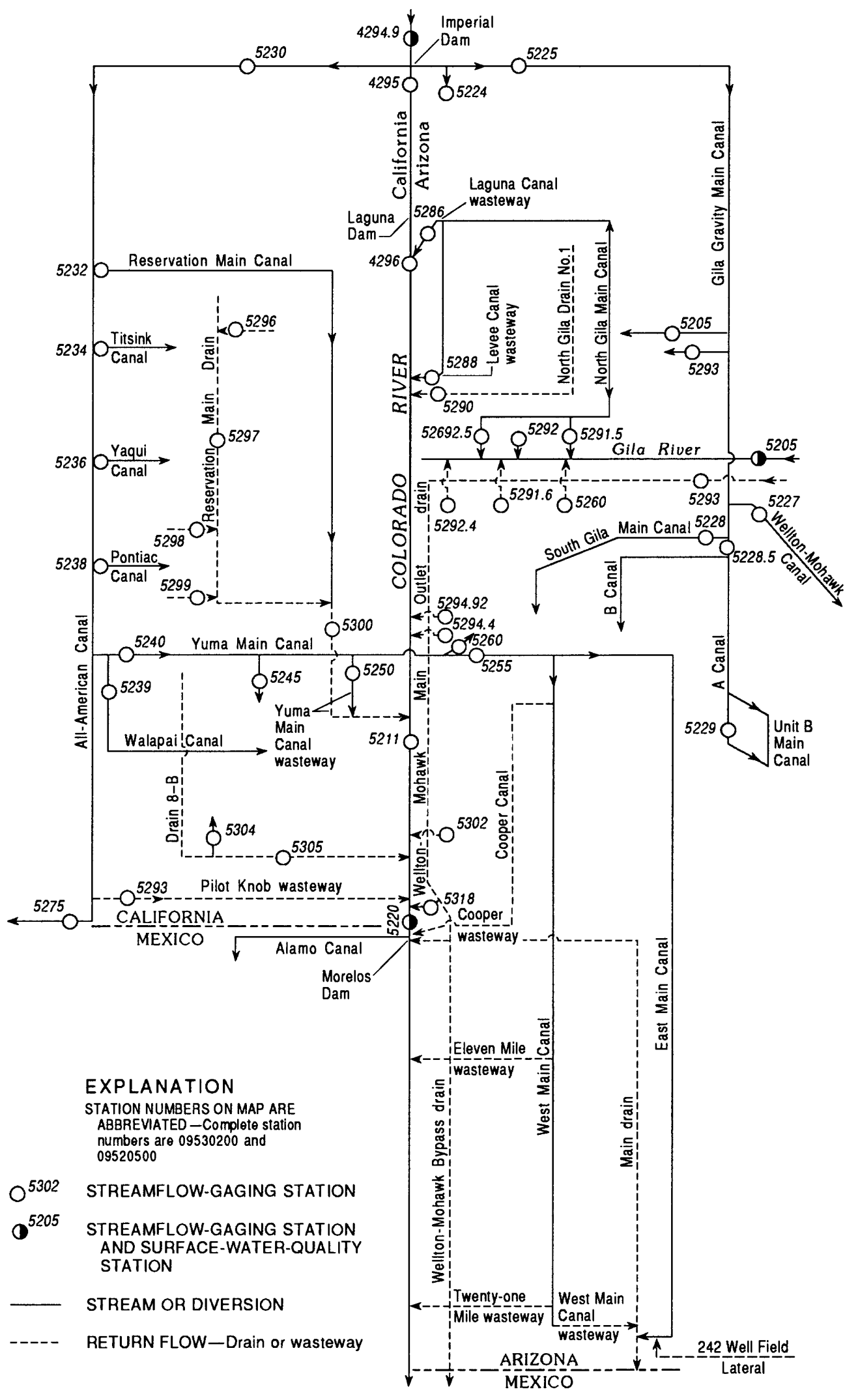

Figure 6. Streamflow-gaging stations and surface-water-quality stations on streams, diversions, and return flows between Imperial Dam and the southerly international boundary. 


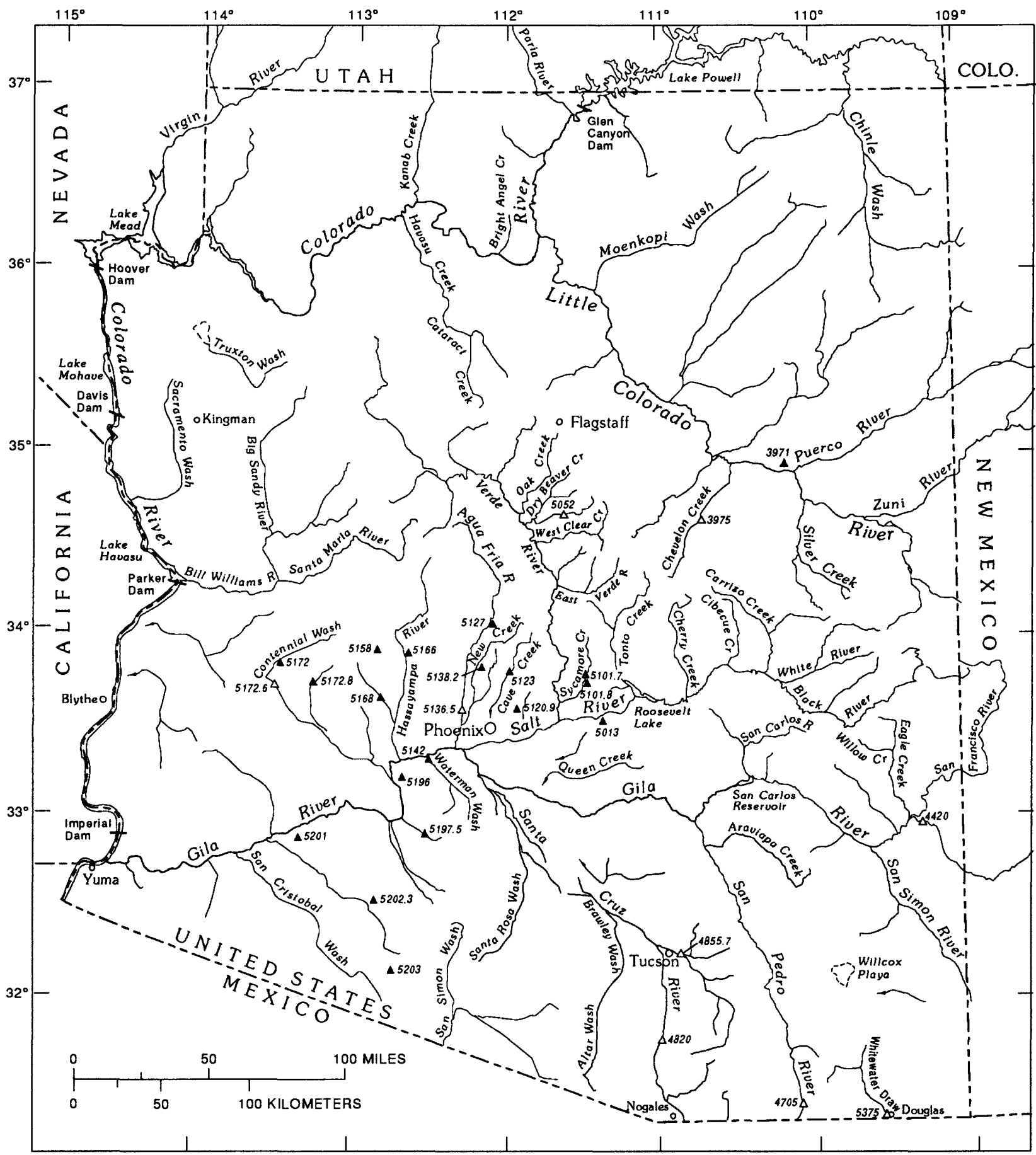

Base from U.S. Geological Survey

State base maps, $1: 500,000$,

New Mexico, 1965; and Utah, 1959

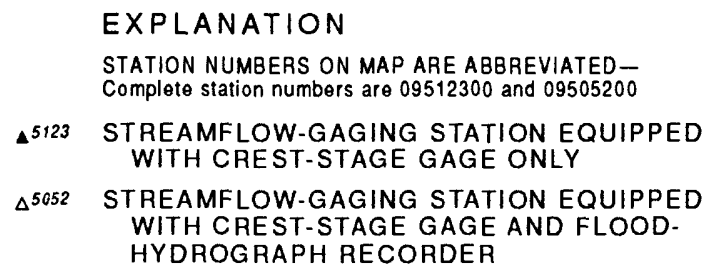

Figure 7. Partial-record streamflow-gaging stations, water year 1990. 

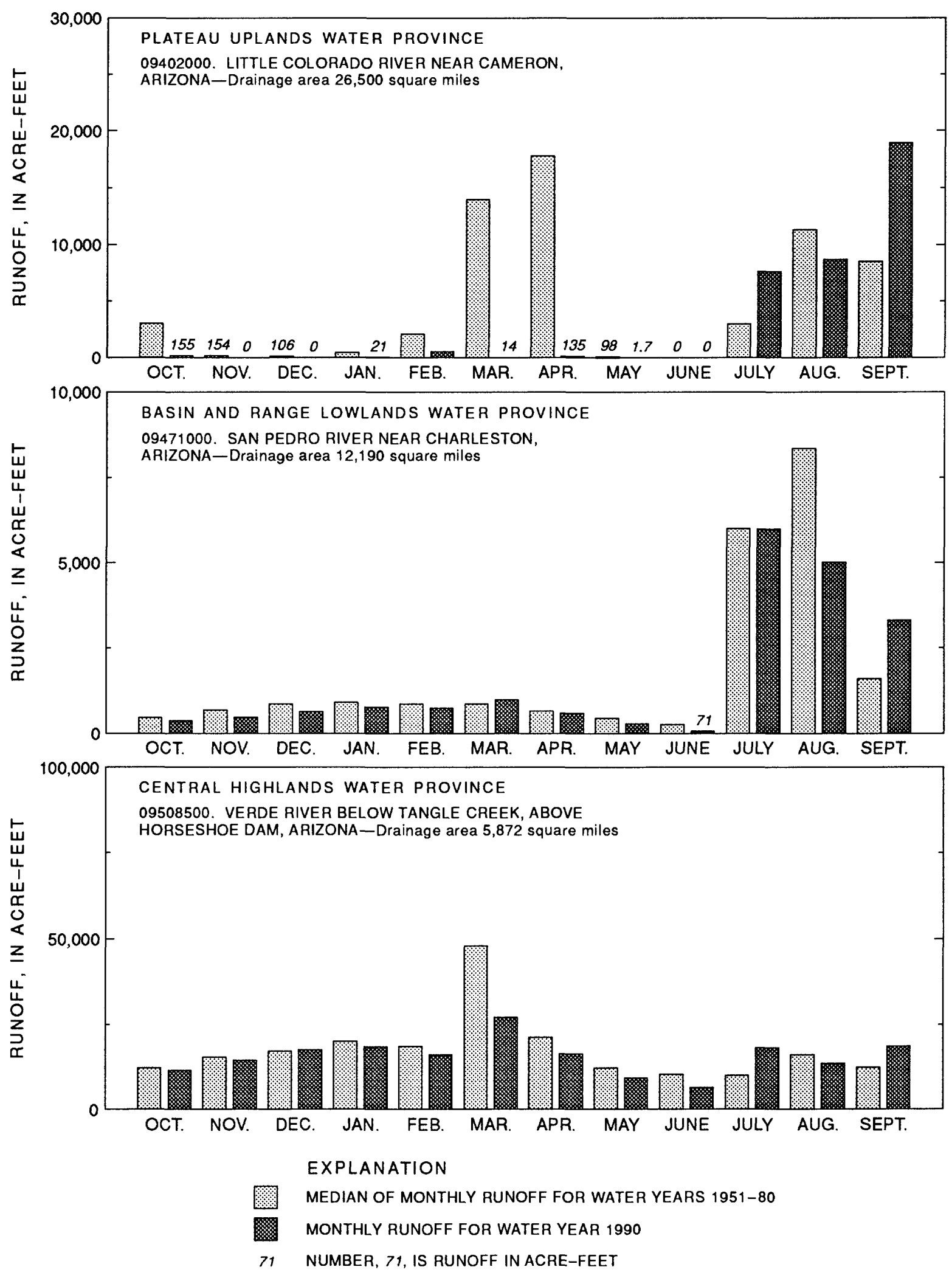

Figure 8. Runoff during water year 1990 compared with median runoff for water years $1951-80$ for three representative streamflow-gaging stations. 


\section{Ground Water}

The Basin and Range lowlands province is the most highly developed of the three water provinces. In 1986, about 3.03 million acre-feet of ground water was withdrawn in the province, which was more than 94 percent of the total ground-water withdrawal in the State. Water levels in selected wells are shown in figure 9 . In general, most water levels declined significantly during the 1950's through the 1970's when ground-water withdrawal was the greatest. Since the mid1970's, however, ground-water withdrawal has decreased and the rate of water-level declines has been reduced, and in some areas, water levels are rising. The Central highlands province is the transition zone between the other two provinces and is the smallest. Only a few thousand acres of land is cultivated and the quantity of ground water withdrawn has not resulted in notable waterlevel declines. In 1986, about 89,000 acre-feet of water was withdrawn in the province. In the Plateau uplands province, ground-water development is small compared with that in the Basin and Range lowlands province. Ground water is used mainly by scattered farms and homesites, industrial and utility sites, and a few population centers. In 1986, about 96,000 acre-feet of water was withdrawn. For the most part, no pattern of rise or decline in water levels is discernible, although 10 to 20 feet of decline has occurred in a few areas in the Plateau uplands province.

\section{Quality of Water}

Many rivers in Arizona provide water suitable for most uses, although human activities have adversely affected the quality of surface water in parts of the State. In 1990, surface-waterquality data were collected at 45 sites (fig. 10). Hydrologic modifications in the form of dams, reservoirs, diversion canals, vegetation removal, sand and gravel mining, and irrigation return flows have had a significant negative effect on native fish and wildlife in Arizona and directly impair water quality. Livestock grazing, mining activities, intense recreational use, and urbanization have also negatively affected stream quality.

Quality of the ground water is a major concern because ground water is the principal source for public supply. Most of the ground water is of suitable quality for human consumption and most other uses, although ground-water-quality problems exist locally at several locations throughout the State. Ground-water-quality problems attributed to anthropogenic and naturally occurring contamination can be found throughout Arizona. In some areas, changes in ground-water quality are caused by (1) recirculation of salts in irrigation water, (2) leachates from mining operations, (3) disposal of toxic wastes, (4) leaking underground storage tanks, and (5) leachates from landfills.

\section{Water Use}

Water-use patterns in Arizona are dominated primarily by agriculture and secondarily by rapidly growing urban population centers in Maricopa and Pima Counties. Almost all field and orchard crops are irrigated because the climate is semiarid and precipitation is too little and erratic to be useful for growing crops. Land irrigated by surface water is concentrated in the valleys and basins near the Colorado, Gila, Salt, and Verde (Yavapai County) Rivers. Land irrigated by ground water is mainly in the alluvial basins in the southern and the western parts of the State. 

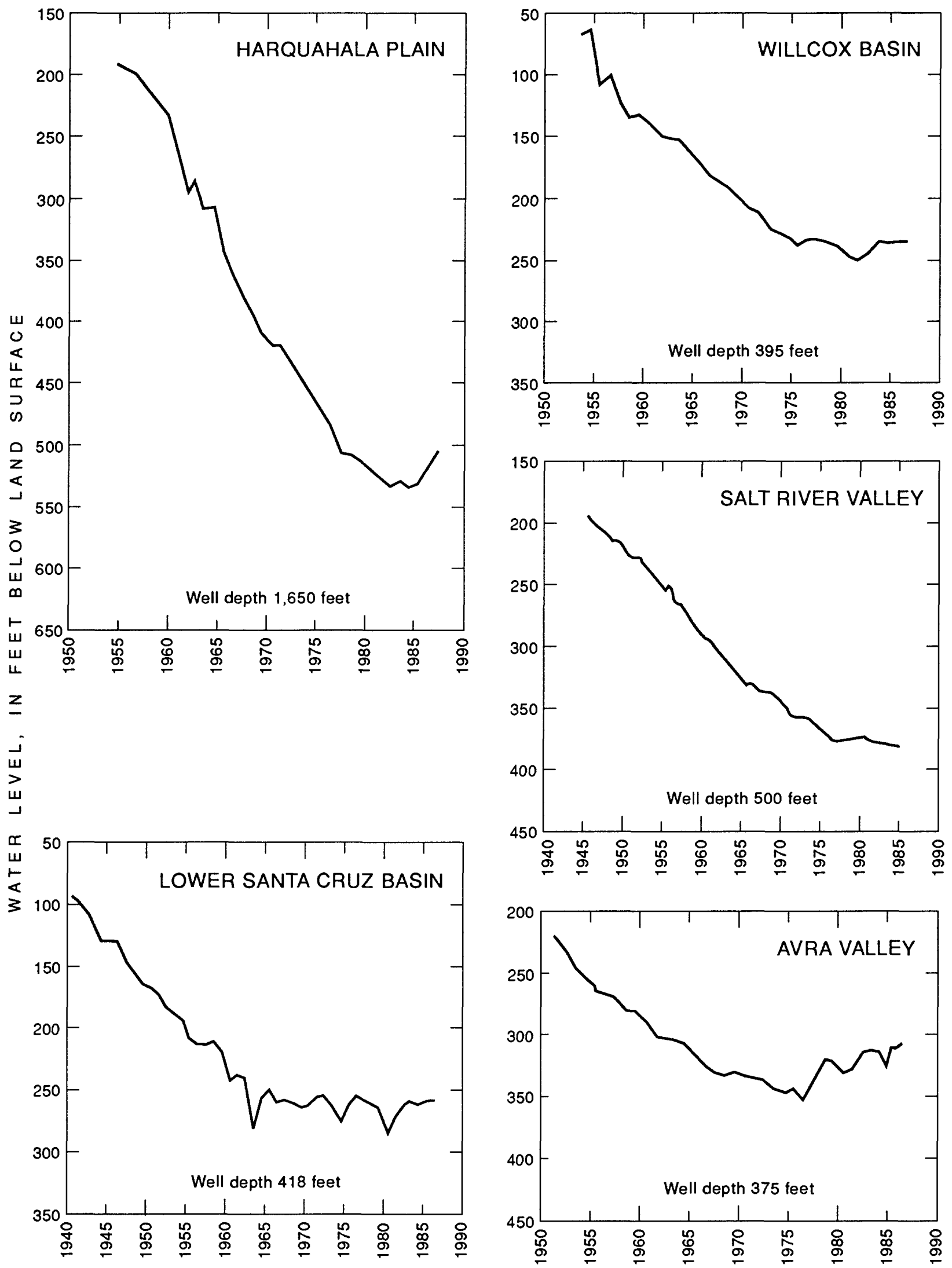

Figure 9. Water level in selected wells in the Basin and Range lowlands province. 


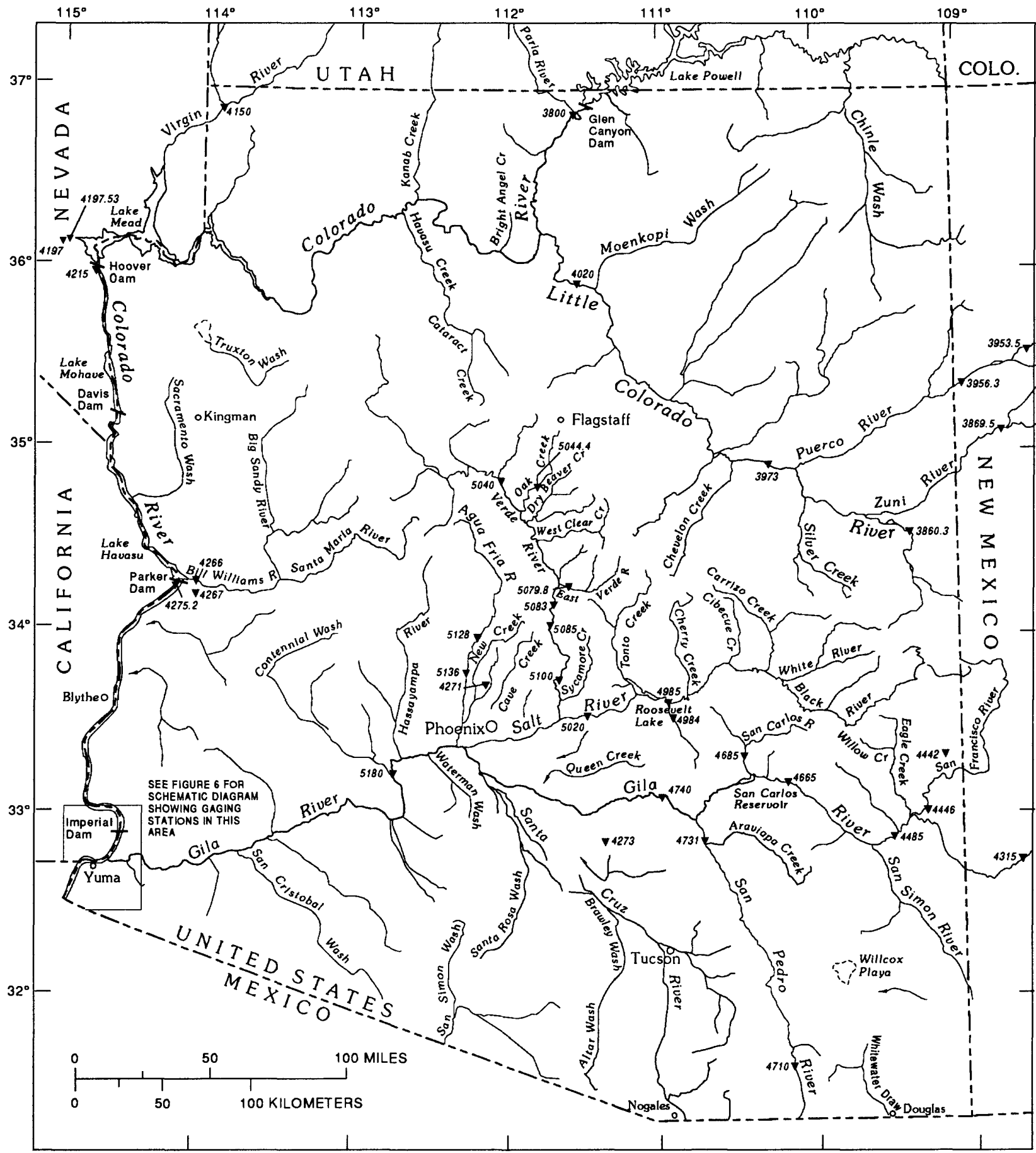

Base from U.S. Geological Survey

State base maps, 1:500,000,

New Mexico, 1965; and Utah, 1959

EXPLANATION

$\checkmark 4740$ SURFACE-WATER-QUALITY SITES

AND ABBREVIATED NUMBER-

Complete station number is

09474000

Figure 10. Surface-water-quality sites, water year 1990 . 
PROJECTS FUNDED IN FISCAL YEARS 1986-91

$-17$.

PAGE 19 FOLLOWS 


\section{Surface-Water Stations (AZ001)}

Location: Statewide (see figure 5)

Project Chief: Fred C. Boner, 1986-90;

Edwin H. McGavock, 1990-present

Period of Project: Continuous since 1912

Cooperating Agencies: Arizona Department of Environmental Quality, Arizona Department of Health Services, Arizona Department of Water Resources, City of Tucson, Flood Control District of Maricopa County, Gila Valley Irrigation District, Maricopa County Municipal Water Conservation District No. 1, Metropolitan Water District of Southern California, Pima County Board of Supervisors, Salt River Valley Water Users' Association, San Carlos Irrigation and Drainage District, Show Low Irrigation Company, Bureau of Land Management, Bureau of Reclamation, Fish and Wildlife Service, National Park Service, and Corps of Engineers.

Problem: Surface-water runoff is highly variable, both areally and seasonally, throughout the State. Information is needed for purposes of surveillance, planning, design, hazard warning, and management. Monitoring of runoff is essential to water-related fields such as water supply, hydroelectric power, flood control, irrigation, bridge and culvert design, wildlife management, pollution abatement, flood-plain management, and water-resources development. An appropriate data base is necessary to provide this information.

Objectives: Maintain a network of surface-water stations to collect streamflow data needed for (1) assessment of surface-water resources; (2) operating reservoirs for power, flood control, and irrigation; (3) flow forecasting; (4) monitoring of flow for instream-use requirements; (5) waterquality estimates; (6) waste disposal and pollution control; (7) compact and legal requirements; and (8) defining statistical streamflow characteristics needed for research, planning, and design of dams, bridges, culverts, canals, flood-management projects, and ground-water-recharge facilities.

Approach: Standard U.S. Geological Survey methods are used to measure and record stage and discharge of streams and stage and contents of lakes and reservoirs. Frequency of data collection is determined by the principal purpose of each site.

\section{Progress and Significant Results:}

FY1986: Surface-water data were collected and compiled for publication for 171 continuous streamflow stations, 21 partial-record peak-flow stations, 10 lakes and reservoirs, and 22 supplemental streamflow stations.

FY1987: Surface-water data were collected and compiled for publication for 168 continuous streamflow stations, 22 partial-record peak-flow stations, 10 lakes and reservoirs, and 20 supplemental streamflow stations. 
FY1988: Surface-water data were collected and compiled for publication for 169 continuous streamflow stations, 24 partial-record peak-flow stations, 10 lakes and reservoirs, and 20 supplemental streamflow stations.

FY1989: Surface-water data were collected and compiled for publication for 179 continuous streamflow stations, 25 partial-record peak-flow stations, 10 lakes and reservoirs, and 20 supplemental streamflow stations.

FY1990: Surface-water data were collected and compiled for publication for 180 continuous streamflow stations, 23 partial-record peak-flow stations, 10 lakes and reservoirs, and 20 supplemental streamflow stations.

FY1991: Surface-water data were collected and compiled for publication for 189 continuous streamflow stations, 28 partial-record peak-flow stations, 10 lakes and reservoirs, and 20 supplemental streamflow stations.

Plans for Next Year: Statewide data collection and review will continue. Satellite data-relay transmitters are operated at 178 stations. Installation of additional satellite data-collection platforms is planned for real-time transmission of streamflow information from selected remote stations. Four stations will be discontinued because of lack of cooperator funding, and four stations may be discontinued because of decreased Federal matching funds.

\section{Reports:}

Boner, F.C., Garrett, W.B., and Konieczki, A.D., 1989, Water resources data for Arizona, water year 1988: U.S. Geological Survey Water-Data Report AZ-88-1, 391 p.

Boner, F.C., Smith, C.F., Garrett, W.B., and Konieczki, A.D., 1990, Water resources data for Arizona, water year 1989: U.S. Geological Survey Water-Data Report AZ-89-1, 383 p.

White, N.D., and Garrett, W.B., 1986, Water resources data for Arizona, water year 1983: U.S. Geological Survey Water-Data Report AZ-83-1, 387 p.

1987, Water resources data for Arizona, water year 1984: U.S. Geological Survey Water-Data Report AZ-84-1, 381 p.

1988, Water resources data for Arizona, water year 1985: U.S. Geological Survey Water-Data Report AZ-85-1, 343 p.

Wilson, R.P., and Garrett, W.B., 1988, Water resources data for Arizona, water year 1986: U.S. Geological Survey Water-Data Report AZ-86-1, 341 p.

1989, Water resources data for Arizona, water year 1987: U.S. Geological Survey Water-Data Report AZ-87-1, 385 p. 


\section{Ground-Water Stations (AZ002)}

Location: Statewide

Project Chief: Natalie D. White, 1986; Richard P. Wilson, 1986-89; Alice D. Konieczki, 1989-91; Herbert H. Schumann, 1991-present

Period of Project: Continuous since 1939

Cooperating Agency: Arizona Department of Water Resources

Problem: Long-term water-level records are needed to evaluate the effects of climatic variations on the recharge to and discharge from the ground-water systems, provide a data base from which to measure the effects of

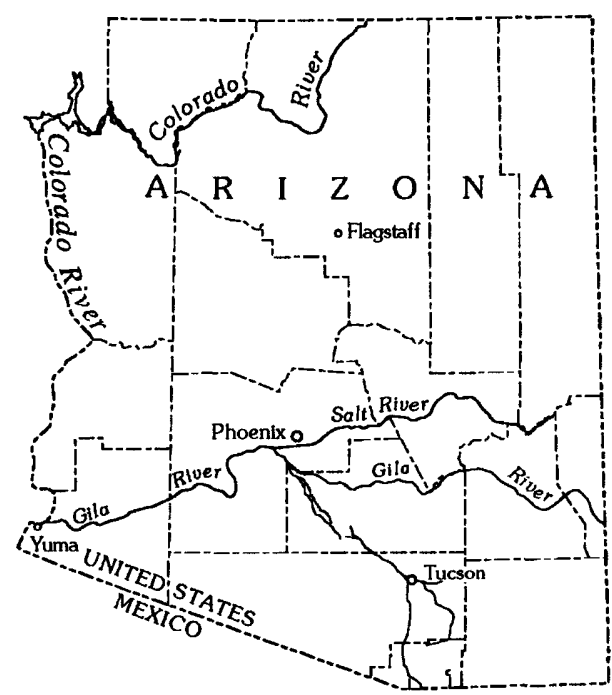
development, assist in the prediction of future supplies, and provide data for management of the resource.

Objectives: (1) Collect ground-water-level data and provide a long-term data base that can be used to monitor the general response of the hydrologic system to natural and manmade stresses. (2) Provide a data base against which the short-term records acquired in areal studies can be analyzed. The analysis must provide an assessment of the ground-water resource, allow prediction of future conditions, and provide the data base necessary for management of the resource.

Approach: The USGS and the Arizona Department of Water Resources (ADWR) jointly measure and maintain a Statewide observation-well network. In 1990, ADWR expanded their role in the operation of the observation-well network. The data are exchanged between agencies. Each year, ADWR conducts investigations in several ground-water areas. The studies include well inventories, water-level measurements, and water-quality samples. The results of the studies are published in the State's Hydrologic Map Series Reports (HMS), which typically show depth to water, change in water levels, altitude of the water level, and quality of water.

Progress and Significant Results, Fiscal Years 1986-91: Between 1986 and 1991, ADWR assumed expanded responsibilities for the collection of ground-water data. Building on the existing USGS monitoring network, ADWR increased the number of ground-water data-collection sites. The data are supplied to the USGS where they are added to Ground Water Site Inventory (GWSI). The State also assumed responsibility for ground-water-basin studies. Between 1986 and 1991, 11 map reports (HMS) documenting ground-water conditions were published by ADWR. Ground-water levels for selected sites were published in the USGS Water Resources Data Reports. Data on ground-water withdrawals and surface-water diversions were collected, computed, and 
compiled for publication in an expanded version of the annual report for 1985-86. The annual summary of ground-water conditions also was published for 1986-87; most of the data for 1987 through 1991 have been collected or compiled.

Plans for Next Year: Data collection, review, and entry into GWSI will continue. Annual summary of ground-water conditions for 1987-88 will be published.

\section{Reports:}

Schumann, H.H., 1988, U.S. Geological Survey ground-water studies in Arizona: U.S. Geological Survey Open-File Report 88-164, Water Fact Sheet, 1 sheet.

U.S. Geological Survey, 1986, Annual summary of ground-water conditions in Arizona, spring 1984 to spring 1985 : U.S. Geological Survey Open-File Report 86-422W, 2 sheets.

Wilson, R.P., 1991, Summary of ground-water conditions in Arizona, 1985-86: U.S. Geological Survey WaterResources Investigations Report 90-4179, 4 sheets. 


\section{Quality of Water Stations (AZ003)}

Location: Statewide (see figure 10)

Project Chief: Dean B. Radtke, 1985-91;

Edwin H. McGavock, 1991-present

Period of Project: Continuous since 1969

Cooperating Agencies: Arizona Department of Environmental Quality, Arizona Department of Water Resources, City of Scottsdale, Bureau of Reclamation, Bureau of Land Management, Army Corps of Engineers.

Problem: Water-resource planning and water-quality assessment require a nationwide base level of relatively standardized information. For intelligent planning and realistic assessment of the water resource, the chemical, biological, and physical quality of the surface water of Arizona must be defined and monitored.

Objectives: Provide a national bank of water-quality data for broad Federal and State planning and action programs and provide data for Federal management of interstate and international waters.

Approach: A network of water-quality stations is operated to provide average chemical concentrations, loads, and time trends as required by planning and management agencies.

Progress and Significant Results, Fiscal Years 1986-91: The sampling and analytical program was continued throughout the year. Data from this program are entered into the National Water Data Storage and Retrieval System (WATSTORE) on a current basis. Data from this project are included in the annual data report.

Plans for Next Year: Continue the water-quality monitoring program with one less surfacewater/water-quality site because of decreased matching funds.

\section{Reports:}

Boner, F.C., Garrett, W.B., and Konieczki, A.D., 1989, Water resources data for Arizona, water year 1988: U.S. Geological Survey Water-Data Report AZ-88-1, 391 p.

Boner, F.C., Smith, C.F., Garrett, W.B., and Konieczki, A.D., 1990, Water resources data for Arizona, water year 1989: U.S. Geological Survey Water-Data Report AZ-89-1, 383 p.

Kister, L.R., Radtke, D.B., and Graf, Chuck, 1988, Arizona ground-water quality, in Moody, D.W., Carr, Jerry, Chase, E.B., and Paulson, R.W., compilers, National Water Summary 1986-Hydrologic Events and Ground-Water Quality: U.S. Geological Survey Water-Supply Paper 2325, p. 157-164. 
White, N.D., and Garrett, W.B., 1986, Water resources data for Arizona, water year 1983: U.S. Geological Survey Water-Data Report AZ-83-1, 387 p.

1987, Water resources data for Arizona, water year 1984: U.S. Geological Survey Water-Data Report AZ-84-1, $381 \mathrm{p}$.

1988, Water resources data for Arizona, water year 1985: U.S. Geological Survey Water-Data Report AZ-85-1, 343 p.

Wilson, R.P., and Garrett, W.B., 1988, Water resources data for Arizona, water year 1986: U.S. Geological Survey Water-Data Report AZ-86-1, 341 p.

1989, Water resources data for Arizona, water year 1987: U.S. Geological Survey Water-Data Report AZ-87-1, 385 p. 


\section{Sediment Stations (AZ004)}

Location: Statewide

Project Chief: William B. Garrett, 1986-90;

Dean B. Radtke; 1990-91; Julia B. Graf, 1991-present

Period of Project: Continuous since 1925

Cooperating Agencies: Bureau of Reclamation, Corps of Engineers, Flood Control District of Maricopa County

Problem: Water-resources planning and water-quality assessment require a nationwide data base of relatively standardized information. Erosion, transport, and deposition of sediment can have major effects on streams, lakes, and reservoirs, and knowledge of sediment transport

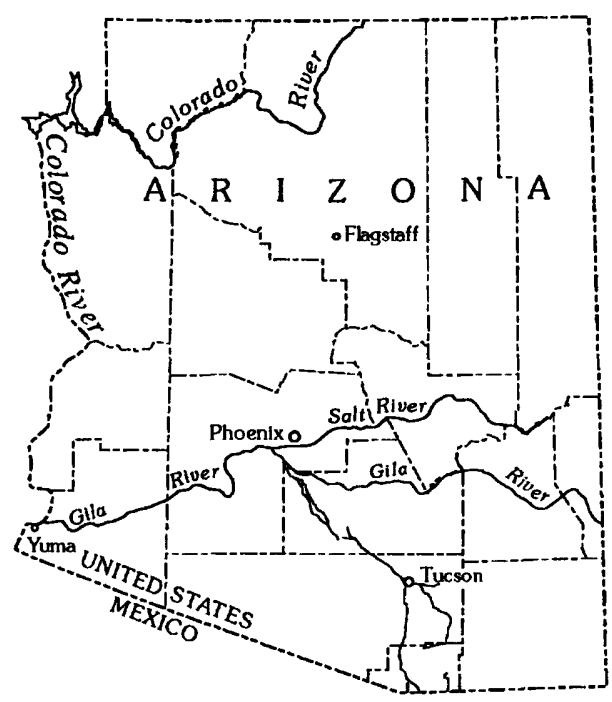
is essential for appropriate planning and assessment. To obtain the necessary information, bed material and suspended-sediment transport must be monitored on a regular basis on a wide variety of streams throughout the country.

Objective: Provide data on bed material and suspended-sediment transport on streams in the arid Southwest to a national data base for use in broad Federal and State planning and action programs and for Federal management of interstate and coastal waters.

Approach: Bed-material and suspended-sediment samples are collected at regular intervals at a network of stations in Arizona, and the data are entered into the national data base. Bed-material samples are collected from one to four times per year. Suspended-sediment samples are collected from 6 to 12 times per year during regular site visits or on a storm basis by automatic sampler.

Progress and Significant Results, Fiscal Years 1986-91: Suspended-sediment and bedmaterial samples were collected during regular site visits at gaging stations 09473100, San Pedro River below Aravaipa Creek near Mammoth, and 09474000, Gila River at Kelvin. Suspendedsediment samples were collected during some storms at gaging station 09397100, Leroux Wash near Joseph City. Suspended-sediment samples were collected by automatic sampler at gaging station 09397300, Little Colorado River near Joseph City. Data for the San Pedro and Gila River sites were published annually from 1986 to 1991. For the San Pedro River, 52 instantaneous suspended-sediment concentration values and 13 bed-material grain-size distributions were published. For the Gila River, 54 instantaneous suspended-sediment concentrations and 31 bedmaterial grain-size distributions were published. Daily suspended-sediment discharge was 
published for 1986 for the Little Colorado River site for days on which the instantaneous discharge exceeded $500 \mathrm{ft}^{3} / \mathrm{s}$. No data for Leroux Wash were published for water years 1986-91.

Plans for Next Year: Collection of data will continue at the four sites listed above. In addition, suspended sediment will be collected by automatic sampler at gaging station 09401000 , Little Colorado River at Grand Falls. Samples were collected at that site from 1989 to 1991 as a part of project AZ104, "Radionuclide transport in the Puerco River." Instantaneous suspended-sediment concentration and bed-material grain-size distribution for the San Pedro and Gila River sites will be published for water year 1992. Instantaneous suspended-sediment concentrations for the Leroux Wash site will be published for water years 1986-92. Daily suspended-sediment discharge for days on which the instantaneous discharge exceeded 500 cubic feet per second at the Little Colorado River near Joseph City site will be published for water years 1987-92. Daily suspendedsediment discharge for the gaging station on the Little Colorado River at Grand Falls will be published for water years 1989-92.

\section{Reports:}

Boner, F.C., Garrett, W.B., and Konieczki, A.D., 1989, Water resources data for Arizona, water year 1988: U.S. Geological Survey Water-Data Report AZ-88-1, 391 p.

Boner, F.C., Smith, C.F., Garrett, W.B., and Konieczki, A.D., 1990, Water resources data for Arizona, water year 1989: U.S. Geological Survey Water-Data Report AZ-89-1, 383 p.

White, N.D., and Garrett, W.B., 1986, Water resources data for Arizona, water year 1983: U.S. Geological Survey Water-Data Report AZ-83-1, 387 p.

1987, Water resources data for Arizona, water year 1984: U.S. Geological Survey Water-Data Report AZ-84-1, 381 p.

1988, Water resources data for Arizona, water year 1985: U.S. Geological Survey Water-Data Report AZ-85-1, 343 p.

Wilson, R.P., and Garrett, W.B., 1988, Water resources data for Arizona, water year 1986: U.S. Geological Survey Water-Data Report AZ-86-1, 341 p.

1989, Water resources data for Arizona, water year 1987: U.S. Geological Survey Water-Data Report AZ-87-1, 385 p. 


\section{Studies for Federal Insurance Administration, Department of Housing and Urban Development (AZ006)}

Location: Central and south-central Arizona

Project Chief: Stanley Baldys, III, 1986-90;

Edward G. Nassar, 1990; Jeff V. Phillips, 1990-91

Period of Project: January 1973 to September 1991

Cooperating Agency: Federal Emergency Management Agency

Problem: The National Flood Insurance Act of 1968 provides that the Department of Housing and Urban Development (HUD) operate a flood-insurance program through the Federal Insurance Administration (FIA).

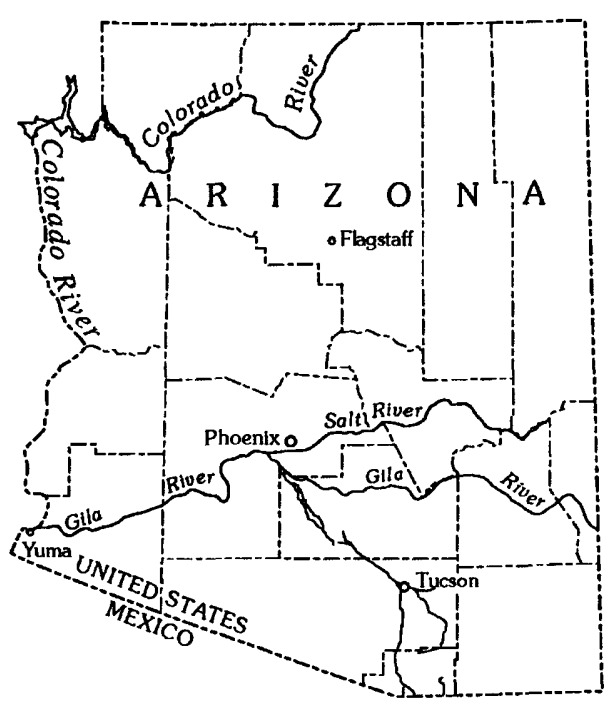
HUD needs flood studies in selected areas to determine applicable flood-insurance premium rates.

Objectives: Conduct the necessary hydrologic and hydraulic studies of the areas assigned by the Federal Insurance Administration on a month-to-month basis and to develop the most efficient procedures to attain the accuracy specified by FIA in the most appropriate format with minimum personnel requirements.

Approach: Conduct necessary surveys by ground and photogrammetric methods, prepare computer models of drainage networks, compute magnitudes and profiles of floods of specified frequencies, and furnish results in reports prepared to FIA specifications.

Progress and Significant Results, Fiscal Years, 1986-91: The 100-year flood profiles and floodway analysis for Rodeo Wash and Railroad Wash were completed and submitted to the Federal Emergency Management Agency in 1990.

Plans for Next Year: The 100-year flood profiles and floodway analysis for Baderville tributary to Rio de Flag near Flagstaff will be completed and submitted to the Federal Emergency Management Agency.

Reports: Administrative reports for each flood study containing maps of flood-prone areas, graphs of flood profiles, and results of computer modeling have been submitted to the Federal Emergency Management Agency. 
Location: Statewide

Project Chief: Richard P. Wilson, 1986-90;

Herbert H. Schumann, 1990-91

Period of Project: Continuous since June 1979

Cooperating Agency: Arizona Department of Water Resources

Problem: Water-use data are presently collected by several local, State, and Federal agencies. Water use refers to the quantity of water withdrawn and used for agricultural, industrial, power-generation, municipal, or

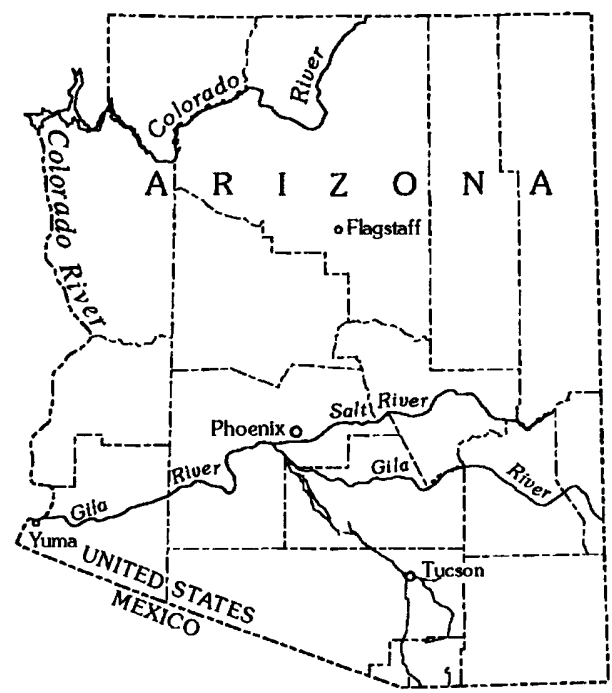
domestic purposes and returned to the ground-water or surface-water system. A comprehensive water-use data base was needed to provide (1) data for planners or governmental agencies that need generalized information relating water use to irrigated acreage, ore production, municipal use, and other uses; (2) data with areal and temporal detail that can be used to model and evaluate management alternatives; and (3) easy accessibility.

Objectives: Provide information on water-use rates and consumptive use by area for specific time periods so decisions regarding changes in delivery systems and associated economic studies can be realistically made. Provide a data base of ground-water withdrawals that can be used to evaluate management alternatives through modeling techniques. Provide a data base that is easily accessible by authorized agencies and which, at the same time, will honor and protect the privacy of individual water users. The data base will be expandable to accommodate new development and will permit the removal of out-of-date or abandoned points of withdrawal.

Approach: Data on ground-water withdrawals and surface-water diversions are obtained directly from companies or other government agencies wherever possible. Where flow meters are not in use, power records and pump-efficiency data will be obtained to compute withdrawal. A shift in emphasis was made in 1984 when flow meters, required as a result of the new State ground-water law, were put in use in the State-designated Active Management Areas.

Progress and Significant Results, Fiscal Years 1986-91: Water-use data were collected, entered into Estimated Use of Water in the United States files, and included as a section in the 1987 National Water Summary that was published in 1990. The data also are included in U.S. Geological Survey Circular 1081, "Estimated Use of Water in the United States in 1990," by W.B. Solley, R.R. Pierce, and H.A. Perlman. 
Plans for Next Year: Continue to obtain data on ground-water withdrawals and surface-water diversions directly from companies whenever possible. Obtain power records and pumpefficiency data to compute withdrawal in other areas of the State. The annual data will be compiled and published.

\section{Report:}

Wilson, R.P., 1990, Arizona water supply and use, in Carr, J.E., Chase, E.B., Paulson, R.W., and Moody, D.W., compilers, National Water Summary 1987-Hydrologic Events and Water Supply and Use: U.S. Geological Survey Water-Supply Paper 2350, p. 157-164. 
Location: Statewide

Project Chief: Robert D. Mac Nish

Period of Project: Continuous since 1971

Cooperating Agencies: Other Federal agencies

Problem: Other Federal agencies occasionally require the assistance of the USGS for special small-scale studies to assist them in their work.

Objectives: To provide technical assistance to other

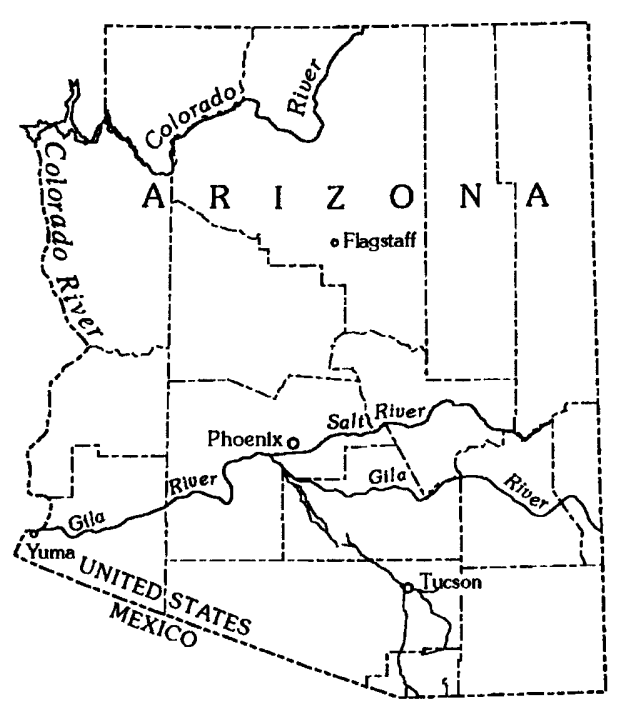
Federal agencies for small-scale assignments of a consulting nature.

Approach: Provide technical assistance as requested.

Progress and Significant Results, Fiscal Years 1986-91: Consulting services and technical assistance were provided as requested by other Federal agencies.

Plans for Next Year: Continue work for other Federal agencies as requested. 


\section{Reconnaissance Study of Water Supply of Lake Mead National \\ Recreation Area (AZ024)}

Location: Northwestern Arizona

Project Chief: Robert L. Laney

Period of Project: September 1971 to October 1979

Cooperating Agency: National Park Service

Problem: Because of the expanding need for recreation facilities in the Lake Mead National Recreation Area, the National Park Service has a continuing program for the development of the facilities. The long-range plan for the development of the area called for the development of water supplies at various recreational sites adjacent to the

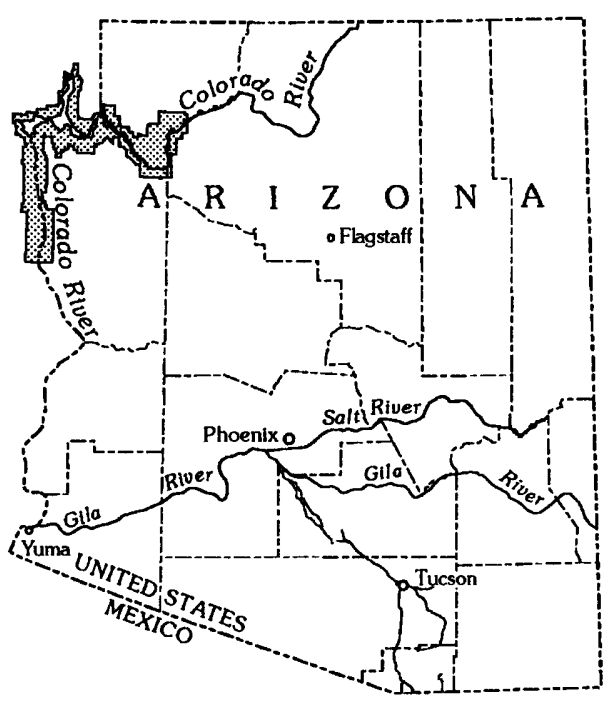
lakes. The USGS assisted the Park Service in evaluating the water supplies at these sites.

Objectives: Determine sources and chemical quality of all potential water supplies in the recreation area. Data obtained from this study will supply information needed to evaluate the overall water supply for the area.

Approach: A geologic map of each area will be prepared from field mapping and published reports. An inventory will be made of all wells and springs in the area and will include depth to water, well production, quality of water, and well logs. With these data and similar data obtained in adjacent areas, an analysis will be made of the ground-water potential. Surface-flow and spring data will be collected to determine if any usable surface-water supply is available. Because the area is one of low relief and little precipitation, the only surface-water potential for development probably is the lake itself.

Progress and Significant Results, Fiscal Years 1986-91: The report, "Geohydrology of the Lake Mead National Recreation Area-Virgin River to Grand Wash Cliffs," has been prepared for publication. Seven reports were published for this project from 1971 to 1982.

Plans for Next Year: Fieldwork will be done in the study area for the final report, "Geohydrology of the Lake Mead National Recreation Area-Las Vegas Wash to Virgin River," and the report will be written. The Virgin River to Grand Wash Cliffs report will be published in fiscal year 1992. 


\section{Monitoring Hydrologic Effects of Ground-Water Withdrawals and Strip Mining at Black Mesa (AZ028 and AZ080)}

Location: Northeastern Arizona

Project Chief: G.W. Hill, 1984-89; R.J. Hart, 1988-90; J. P. Sottilare, 1990-91; G.R. Littin, 1991

Period of Project: Continuous since 1971

Cooperating Agencies: Arizona Department of Water Resources and Bureau of Indian Affairs

Problem: Strip mining of coal on Black Mesa has caused concern by Navajo and Hopi Indians, environmental groups, and Federal agencies about the effects of this strip mining and associated ground-water withdrawals as they

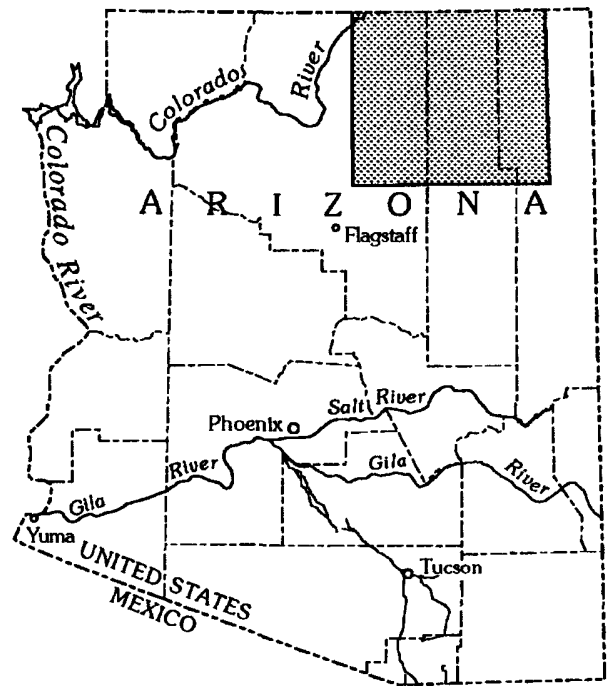
relate to changing the potentiometric water surface of the $\mathrm{N}$ aquifer (Navajo Sandstone).

Objectives: Determine the magnitude of any water-level changes in the $\mathrm{N}$ aquifer near Black Mesa and differentiate changes caused by pumping by Peabody Coal Company and by nearby communities for public supply.

Approach: Observation wells will be used in addition to Peabody Coal Company wells to monitor water-level changes in the $\mathrm{N}$ aquifer. Flow meters will measure pumpage from all public-supply wells and Peabody wells to determine the total quantity of pumpage from the system.

Progress and Significant Results, Fiscal Years 1986-91: Data including water levels and water quality from selected wells, water quality and discharge from selected springs, annual pumpage from the coal-mine well field and Indian communities, and continuous- and partial-discharge data on three streams were collected. Pumpage was updated for the ground-water flow model, and the model was rerun. Several annual reports describing significant results of monitoring efforts have been published since the program began in 1971 .

Plans for Next Year: Continue the same data-collection network and evaluate monitoring data. Prepare the annual progress report.

\section{Reports:}

Brown, J.G., and Eychaner, J.H., 1988, Simulation of five ground-water withdrawal projections for the Black Mesa area, Navajo and Hopi Indian Reservations, Arizona: U.S. Geological Survey Water-Resources Investigations Report 88-4000, $51 \mathrm{p}$. 
Hart, R.J., and Sottilare, J.P., 1988, Progress report on the ground-water, surface-water, and quality-of-water monitoring program, Black Mesa area, northeastern Arizona-1987-88: U.S. Geological Survey Open-File Report 88-467, 27 p.

1989, Progress report on the ground-water, surface-water, and quality-of-water monitoring program, Black Mesa area, northeastern Arizona-1988-89: U.S. Geological Survey Open-File Report 89-383, 33 p.

Hill, G.W., 1985, Progress report on Black Mesa monitoring program-1984: U.S. Geological Survey Open-File Report 85-483, 24 p.

Hill, G.W., and Sottilare, J.P., 1987, Progress report on the ground-water, surface-water, and quality-of-water monitoring program, Black Mesa area, northeastern Arizona-1987: U.S. Geological Survey Open-File Report 87-458, 29 p.

Hill, G.W., and Whetten, M.I., 1986, Progress report on Black Mesa monitoring program-1985-86: U.S. Geological Survey Open-File Report 86-414, 23 p. 


\section{Land subsidence and earth fissures along the proposed Salt-Gila and Tucson aqueducts, Maricopa, Pinal, and Pima Counties, Arizona (AZ047)}

Location: Southern Arizona

Project Chief: Herbert H. Schumann

Period of Project: October 1977 to September 1986

Cooperating Agency: Bureau of Reclamation

Problem: The Bureau of Reclamation proposed that a section of the Central Arizona Project Canal cross Maricopa, Pinal, and Pima Counties. The land surface is subsiding as much as 0.2 foot per year and earth fissures are present in places along the proposed route of the canal. The Bureau will need to know where land subsidence will

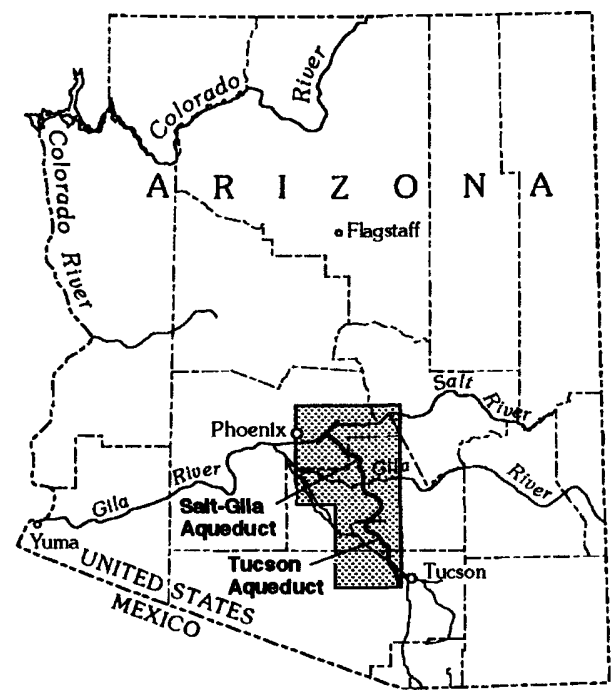
most likely occur, the rate of subsidence, the expected maximum amount of subsidence, and the areas on or near the proposed route that are most likely and least likely to develop earth fissures.

Objective: Rate and magnitude of land subsidence and occurrence of fissuring were related to dewatering of saturated alluvial sediments. The geology of the basins traversed by or adjacent to the Salt-Gila and Tucson aqueducts was evaluated. Estimates were made of the amount of subsidence that may occur over the next 50 years along the route of the aqueducts. Areas that may be subject to earth fissuring were identified along with the relative probability of fissures occurring along the proposed route of the aqueducts.

Approach: An extensive data-collection effort was conducted along the proposed alignment of the Salt-Gila and Tucson aqueducts including records of measured land subsidence; records from compaction recorders in extensometer wells; geophysical surveys such as gravity, resistivity, and refraction- and reflection-seismic surveys; and evaluation of laboratory tests of permeability and compaction performed on cuttings and cores from test holes. Also, test holes were drilled, some for use as extensometers and others as water-level observation wells.

Progress and Significant Results, Fiscal Years 1986-91: The field work, data compilation, and data analysis are completed. The zones of earth-fissure hazards were identified, and estimates were made of land subsidence along the aqueduct routes. The final report has been written and reviewed; revision is in progress for next technical review.

Plans for next year: Complete final report. 


\section{Reports:}

Laney, R.L., and Pankratz, L.W., 1987, Investigations of land subsidence and earth fissures near the Salt-Gila aqueduct, Maricopa and Pinal Counties, Arizona-Altitudes of the tops of the consolidated rocks, surficial geology, and land subsidence in the Florence quadrangle: U.S. Geological Survey Miscellaneous Investigations Series Map I-1892-A, 1 sheet.

Schumann, H.H., 1986, Ground-water depletion and land subsidence in western Pinal County, Arizona, in Conference on Southwestern Ground Water Issues, Tempe, Arizona, October 20-22, 1986, Proceedings: National Water Well Association, p. 533-552.

Schumann, H.H., and Genualdi, R.B., 1986, Land subsidence, earth fissures, and water-level change in southern Arizona: Arizona Bureau of Geology and Mineral Technology, Geological Survey Branch, Map 23, scale $1: 1,000,000,1$ sheet.

Schumann, H.H., Cripe, L.S., and Laney, R.L., 1986, Land subsidence and earth fissures caused by ground-water depletion in southern Arizona, U.S.A., in Land Subsidence: Third International Symposium on Land Subsidence, Venice, Italy, March 19-25, 1984, Proceedings, p. 841-851.

Wallace, B.L., Wrege, B.M., and Schumann, H.H., 1986, Geohydrologic data along the Salt-Gila aqueduct of the Central Arizona Project in Maricopa and Pinal Counties, Arizona: U.S. Geological Survey Open-File Report 86-236, $49 \mathrm{p}$.

Wrege, B.M., 1986, Earth fissure prediction by seismic surface-wave attenuation [abs.], in 30th Annual Meeting of the Arizona-Nevada Academy of Science, Glendale, Arizona, April 19, 1986: Arizona-Nevada Academy of Science, v. 21, p. 50-51.

1986, Surface- and borehole-geophysical surveys used to define hydrogeologic units in south-central Arizona, in Conference on Southwestern Ground Water Issues, Tempe, Arizona, October 20-22, 1986, Proceedings: National Water Well Association, p. 485-499. 


\section{Southwest Alluvial Basins, Regional Aquifer-Systems Appraisal (AZ051)}

Location: Southern and central Arizona and adjacent parts of New Mexico, California, and Nevada

Project Chief: Thomas W. Anderson

Period of Project: September 1978 to September 1986

Cooperating Agency: Regional Aquifer-System Analysis Program (U.S. Geological Survey Federal Program).

Problem: The Southwest alluvial basins (Swab) study was one of about 29 planned or ongoing Regional Aquifer-System Analysis (RASA)

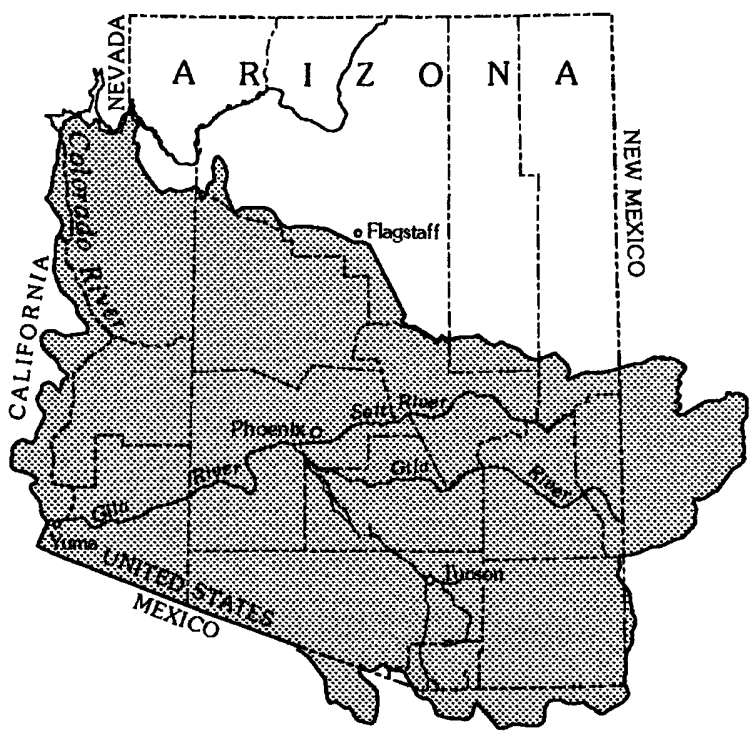
studies included in a major effort by the U.S. Geological Survey throughout the United States. The general problems to be addressed by all RASA projects were to (1) describe the hydraulics and geochemistry of the predevelopment and development ground-water system, (2) analyze changes that have taken place as a result of development, (3) tie together previous small-scale studies, and (4) provide predictive tools by using mathematical-modeling techniques.

Objectives: Evaluate the state of knowledge available to define the aquifer systems, to document the effects of development on water resources, and to explore similarities and differences between the many basin-aquifer systems of the region.

Approach: The nature of the study, the large area, and the diversity of the area in terms of development and hydrologic conditions necessitated a phased approach. Phase 1 included review of available data and existing models in the area and the establishment of priorities for collection of additional data in basins to be studied as "representative." Phase 2 included data acquisition and intensive modeling efforts in specific basins. A preliminary regional model was developed to represent the physical system and the predevelopment ground-water flow system. Phase 3 included finalization of specific and general basin models and development of basin categories.

Progress and Significant Results, Fiscal Years 1986-91: Data were accumulated and analyzed to define the geohydrology of the alluvial basins, magnitude and distribution of historical pumpage, and system response to pumping. Ground-water models were developed and calibrated for 12 specific basins and 2 generic basins. Systematic testing was conducted to evaluate the model response to variations in input parameters, which represented various degrees of uncertainty in the definition of parameter values and areal distributions. The results of the study have been 
documented in nearly 50 reports that were prepared by staff members, cooperating agencies, or contractors.

Plans for Next Year: The final two professional papers are expected to be approved and will be prepared for publication.

\section{Reports:}

Anderson, T.W., 1986, Geohydrology of the Southwest Alluvial Basins, Arizona, in Anderson, T.W., and Johnson, A.I., eds., Regional Aquifer Systems of the United States, Southwest Alluvial Basins of Arizona: American Water Resources Association Monograph Series 7, p. 99-111.

1986, Hydrologic setting, objectives, and approach of the Southwest Alluvial Basins, RASA study, in Anderson, T.W., and Johnson, A.I., eds., Regional Aquifer Systems of the United States, Southwest Alluvial Basins of Arizona: American Water Resources Association Monograph Series 7, p. 5-16.

1986, Study in southern and central Arizona and parts of adjacent states, in Sun, Ren Jen, ed., Regional Aquifer-System Analysis Program of the U.S. Geological Survey, Summary of Projects, 1978-84: U.S. Geological Survey Circular 1002, p. 116-131.

Anderson, T.W., Freethey, G.W., and Tucci, Patrick, 1990, Geohydrology and water resources of alluvial basins in south-central Arizona and parts of adjacent states: U.S. Geological Survey Open-File Report 89-378, 99 p.

Anderson, T.W., Welder, G.E., Lesser, Gustavo, and Trujillo, A., 1988, Region 7, Central Alluvial Basins, in Back, William, Rosenshein, J.S., and Seaber, P.R., eds., The Geology of North America-Hydrogeology: Boulder, Colorado, Geological Society of America, Inc., v. O-2, p. 81-86.

Bedinger, M.S., Anderson, T.W., and Langer, W.H., 1984, Maps showing ground-water units and withdrawal, Basin and Range Province, Arizona: U.S. Geological Survey Water-Resources Investigations Report 83-4114-A, 2 sheets.

Briggs, P.C., and Nemecek, E.A., 1986, Technical aspects of Arizona groundwater law, in Anderson, T.W., and Johnson, A.I., eds., Regional Aquifer Systems of the United States, Southwest Alluvial Basins of Arizona: American Water Resources Association Monograph Series 7, p. 93-98.

Fields, R.L., 1986, Data-processing activities of the Southwest Alluvial Basins, RASA study, in Anderson, T.W., and Johnson, A.I., eds., Regional Aquifer Systems of the United States, Southwest Alluvial Basins of Arizona: American Water Resources Association Monograph Series 7, p. 17-23.

Freethey, G.W., 1986, Considerations in modeling ground-water flow in the alluvial basins of Arizona, in Anderson, T.W., and Johnson, A.I., eds., Regional Aquifer Systems of the United States, Southwest Alluvial Basins of Arizona: American Water Resources Association Monograph Series 7, p. 57-67.

Freethey, G.W., and Anderson, T.W., 1986, Predevelopment hydrologic conditions in the alluvial basins of Arizona and adjacent parts of California and New Mexico: U.S. Geological Survey Hydrologic Investigations Atlas HA-664, 3 sheets.

Freethey, G.W., Pool, D.R., Anderson, T.W., and Tucci, Patrick, 1986, Description and generalized distribution of aquifer materials in the alluvial basins of Arizona and adjacent parts of California and New Mexico: U.S. Geological Survey Hydrologic Investigations Atlas HA-663, 4 sheets.

Hem, J.D., and Robertson, F.N., 1987, Hydrogeochemistry of ground-water recharge in alluvial aquifers, southern Arizona, in Third Symposium on Artificial Recharge of Groundwater in Arizona, May 20-21, 1987, Proceedings: Salt River Project, p. 30-51. 
Pool, D.R., 1986, Aquifer geology of alluvial basins of Arizona, in Anderson, T.W., and Johnson, A.I., eds., Regional Aquifer Systems of the United States, Southwest Alluvial Basins of Arizona: American Water Resources Association Monograph Series 7, p. 25-36.

1987, Hydrogeology of McMullen Valley, west-central Arizona: U.S. Geological Survey Water-Resources Investigations Report 87-4140, 51 p.

Robertson, F.N., 1986, Occurrence and solubility controls of trace elements in ground water in alluvial basins of Arizona, in Anderson, T.W., and Johnson, A.I., eds., Regional Aquifer Systems of the United States, Southwest Alluvial Basins of Arizona: American Water Resources Association Monograph Series 7 , p. 69-80.

1986, Origin and chemistry of ground water along the Colorado River in Arizona, Nevada, and California [abs.], in 30th Annual Meeting of the Arizona-Nevada Academy of Science, Glendale, Arizona, April 19, 1986: Arizona-Nevada Academy of Science, v. 21, p. 56.

1991, Geochemistry of ground water in alluvial basins of Arizona and adjacent parts of Nevada, New Mexico, and California: U.S. Geological Survey Professional Paper 1406-C, 90 p.

Robertson, F.N., and Garrett, W.B., 1988, Distribution of fluoride in ground water in the alluvial basins of Arizona and adjacent parts of California, Nevada, and New Mexico: U.S. Geological Survey Hydrologic Investigations Atlas HA-665, 3 sheets.

Schumann, H.H., Laney, R.L., and Cripe, L.S., 1986, Land subsidence and earth fissures caused by ground-water depletion in southern Arizona, in Anderson, T.W., and Johnson, A.I., eds., Regional Aquifer Systems of the United States, Southwest Alluvial Basins of Arizona: American Water Resources Association Monograph Series 7, p. 81-91.

1989, Geophysical methods for water-resources studies in southern and central Arizona, in Proceedings of the Symposium on the Application of Geophysics to Engineering and Environmental Problems: Denver, Colorado, Society of Engineering and Mineral Exploration Geophysicists, p. 368-383.

Tucci, Patrick, and Pool, D.R., 1986, Use of geophysics for geohydrologic studies in the alluvial basins of Arizona, in Anderson, T.W., and Johnson, A.I., eds., Regional Aquifer Systems of the United States, Southwest Alluvial Basins of Arizona: American Water Resources Association Monograph Series 7, p. 37-56. 


\section{Monitoring Land Subsidence and Determining Earth Fissuring Potential in the Tucson Basin, Pima County, Arizona (AZ053)}

Location: South-central Arizona

Project Chief: Steven A. Anderson, 1978-89;

Randall T. Hanson, 1990-91

Period of Project: October 1978 to September 1991

Cooperating Agency: City of Tucson

Problem: The land surface is subsiding in many of the alluvial valleys in Arizona because of long-term decline of ground-water levels. Earth cracks or fissures have appeared in the valleys of south-central Arizona, mainly in the margins of the basins and generally around the areas of large water-level decline and land subsidence. Land

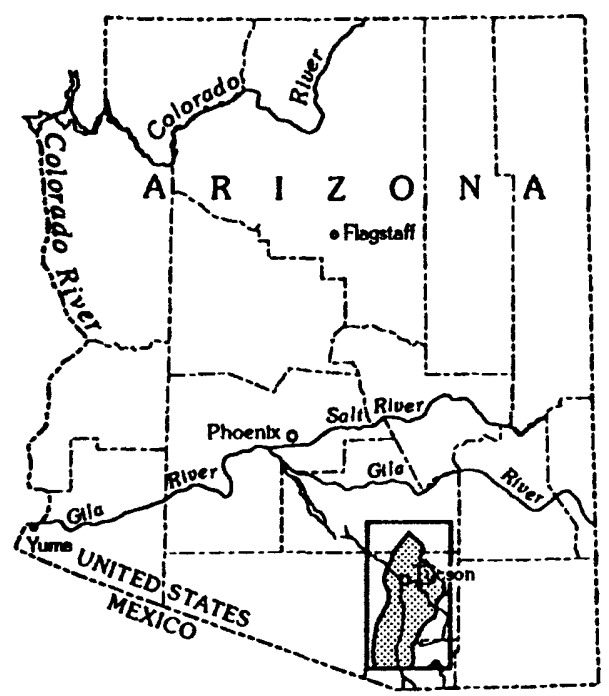
subsidence in the Tucson basin and adjacent Avra Valley is not documented by accurate land-level surveys. The City of Tucson is concerned by the possibility of land subsidence and resultant damage to structures as well as threats to the water supply of the area. The greatest potential for land subsidence is in areas of large water-level decline, in areas containing fine-grained materials in the subsurface, and in lands irrigated south of Tucson along the Santa Cruz River.

Objectives: (1) Monitor and evaluate the occurrence of land subsidence and determine areas of probable occurrence of earth fissures. (2) Develop a method to predict land-surface subsidence. (3) Establish current land-surface datum with respect to sea level.

Approach: Use subsidence recorders on selected extensometer wells and investigate relation between water-level decline, lithology, and measured subsidence. Establish second-order land levels with a globally positioned satellite-surveying system. Data on water-level decline and lithology of the basin sediments in the area are available for comparison with similar data in the Eloy area and other subsidence regions in the southwestern United States.

Progress and Significant Results, Fiscal Years 1986-91: Compaction- and subsidencemonitoring networks for the Tucson basin and Avra Valley were completed. Analysis of extensometer data and compaction models is complete. Analysis of combined ground-water flow and areal subsidence models is nearing completion. Analysis of extensometer data indicates a direct relation of compaction with depositional environments. Compaction modeling provides estimates of hydraulic properties needed for areal subsidence models. Projections of subsidence were made for Avra Valley and the Tucson basin to the year 2025 when, by constitutional law, pumpage must be in balance with recharge in actively managed basins in Arizona. Project results indicate the importance of aquitard specific storage and a need to balance overdraft with recharge 
to abate widespread subsidence. Projections also indicate that a smaller part of ground-water withdrawals are from aquitards when pumping occurs under unconfined or semiconfined conditions in the aquifers.

Plans for Next Year: Continue monitoring at the subsidence recorders. Establish subsidencemonitoring network with global-positioning system and microgravity. The program will be reevaluated for continuation or for formulation of a project aimed for use by managers of water resources of the basin. Report on simulation of subsidence in the Tucson basin will be published.

\section{Reports:}

Anderson, S.R., 1987, Cenozoic stratigraphy and geologic history of the Tucson basin, Pima County, Arizona: U.S. Geological Survey Water-Resources Investigations Report 87-4190, 20 p.

1988, Potential for aquifer compaction, land subsidence, and earth fissures in the Tucson basin, Pima County, Arizona: U.S. Geological Survey Hydrologic Investigations Atlas HA-713, 3 sheets.

1989, Potential for aquifer compaction, land subsidence, and earth fissures in Avra Valley, Pima and Pinal Counties, Arizona: U.S. Geological Survey Hydrologic Investigations Atlas HA-718, 3 sheets.

Anderson, S.R., and Hanson, R.T., 1987, Relation of aquifer compaction to Cenozoic depositional environments in the Tucson basin, Arizona [abs.]: Abstracts with Programs, Geological Society of America Annual Meeting and Exposition, Phoenix, Arizona, October 26-29, 1987, p. 573.

Cuff, M.K., and Anderson, S.R., 1987, Ground-water conditions in Avra Valley, Pima and Pinal Counties, Arizona1985: U.S. Geological Survey Water-Resources Investigations Report 87-4192, 3 sheets.

Hanson, R.T., 1987, One-dimensional modeling of aquifer-system compaction in south-central Arizona [abs.]: American Geophysical Union, v. 68, no. 44, p. 1300-1301.

1989, Aquifer-system compaction, Tucson basin and Avra Valley, Arizona: U.S. Geological Survey Water-Resources Investigations Report 88-4172, $69 \mathrm{p}$.

1989, Simulation of aquifer-system compaction in south-central Arizona [abs.]: 28th International Geological Congress, Washington, D.C., July 9-19, 1989, Abstracts, v. 2, p. $27-28$.

Hanson, R.T., Anderson, S.R., and Pool, D.R., 1990, Simulation of ground-water flow and potential land subsidence, Avra Valley, Arizona: U.S. Geological Survey Water-Resources Investigations Report 90-4178, 41 p.

Schumann, H.H., and Anderson, S.R., 1989, Land-subsidence measurements and aquifer-compaction monitoring in Tucson basin and Avra Valley, Arizona: U.S. Geological Survey Water-Resources Investigations Report $88-4167,15 \mathrm{p}$. 
Location: South-central Arizona

Project Chief: Lee H. Raymond

Period of Project: July 1985 to July 1987

Cooperating Agencies: Arizona State Land Department and National Aeronautics and Space Administration

Problem: Eighty-seven percent of the ground water pumped in Arizona is applied to agricultural areas. Knowing what percentage of this water is actually consumed, and the residual amount and its quality, has critical importance in evaluating the longevity of the water supply in the Southwest. To meet this objective, methods

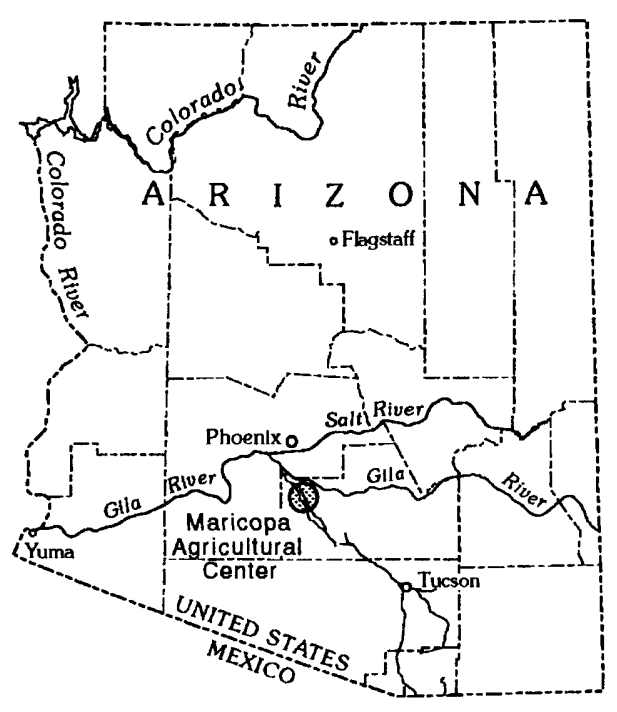
must be developed to estimate or to measure how much water is (1) being diverted or pumped from a basin, (2) being consumptively used by vegetation, and (3) moving down below the root zone.

Objective: Develop a method for determining water use by estimating regional evapotranspiration (ET) more accurately than can be done by present methods. The experiment compared two energy-budget approaches: one using data from airborne scanners and Landsat 5 Thematic Mapper to compute net radiation exchange and the other using data from portable ground-based instruments to calibrate a regional climatic model. The project was conducted in an area where amount and rate of water application and soil-moisture depletion are measured. Consumptive use calculated by the energy-budget methods will be compared to the water budget and to the regional evapotranspiration curves to evaluate the new methods.

Approach: Reflected and emitted radiation data were collected three or four times during the growing season using Landsat Thematic Mapper and airborne scanners. Incoming radiation, ground temperatures, and other calibration data were collected simultaneously in the field. Each satellite and scanner pass was used in an energy budget to calculate 1-day evapotranspiration rates over the entire study area. General water-use curves for each crop were generated from an Agricultural Research Service model and climatic data collected in the field using a Bowen ratio apparatus. These curves were calibrated using the radiation data for each picture element in the satellite and scanner images.

Progress and Significant Results, Fiscal Years 1986-88: The 1-day evapotranspiration model was calibrated successfully using reflected and emitted radiation collected by Landsat Thematic Mapper and the airborne scanner. Attempts to extend the 1-day model into a seasonal model 
calibrated by pixel were not successful because local climatic effects were too variable over the study area to model reliably without more frequent calibration data. Supplying pixel-by-pixel calibration data of the necessary frequency proved to be impractical for an operational method to calculate evapotranspiration. The energy-budget model, however, remained reliable for the fields where the Bowen ratio apparatus was operating as long as the data were collected.

Plans for Next Year: None. Project completed.

\section{Reports:}

Jackson, R.D., Moran, M.S., Gay, L.W., and Raymond, L.H., 1987, Evaluating evaporation from field crops using airborne radiometry and ground-based meteorological data: Irrigation Science, v. 8, p. 81-90.

Moran, M.S., Jackson, R.D., Raymond, L.H., Gay, L.W., and Slater, P.N., 1989, Mapping surface energy balance components by combining Landsat Thematic Mapper and ground-based meteorological data: Remote Sensing of Environment, v. 30, p. 77-87.

Raymond, L.H., Moran, M.S., and Jackson, R.D., 1987, Mapping latent heat energy from remotely sensed data and other variables using geographic information system software: Conference on Spatial Data Systems for Management, University of Arizona, November 5-6, 1987, Proceedings, p. 38-45.

1988, Mapping evapotranspiration using the energy-budget method with remotely sensed data: Symposium on Water-Use Data for Water Resources Management, American Water Resources Association, Tucson, Arizona, August 29-31, 1988, Proceedings, p. 655-665 


\section{Urban Rainfall-Runoff and Runoff Modeling in an Arid Climate, Tucson Metropolitan Area, Pima County, Arizona (AZ069)}

Location: Southern Arizona

Project Chief: Hjalmar W. Hjalmarson, 1981-85; Rodney H. Roeske, 1985-90; Gregory L. Pope, 1990; Christopher F. Smith, 1990-91

Period of Project: July 1981 to September 1992

Cooperating Agencies: Arizona Department of Water Resources and City of Tucson

Problem: Urban runoff in the Tucson area is considered a potential resource. Planners and designers of urban areas need definition of the quantitative characteristics of urban runoff before the fate of urban runoff and pollutants can be determined. Quantitative rainfall-runoff information from

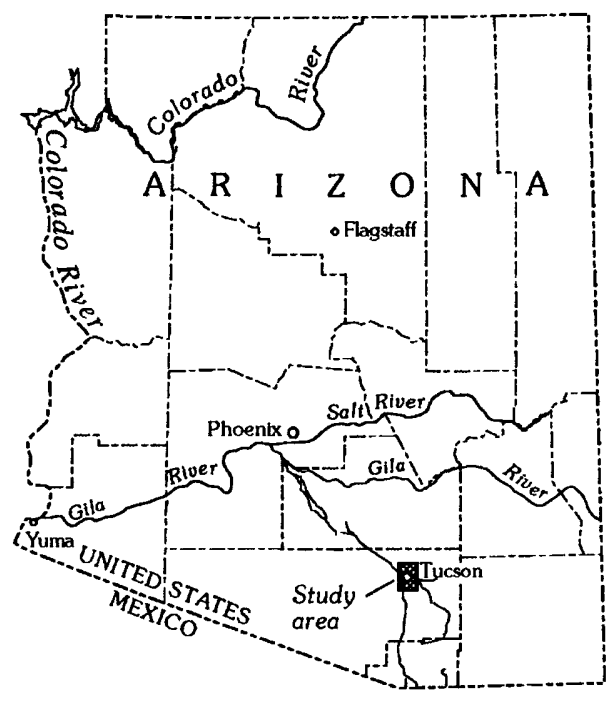
other areas can be intelligently transferred to arid areas like Tucson provided the appropriate relating or transfer functions are known. Only a small number of urban hydrological data may be needed in the Tucson area to utilize the sophisticated deterministic models developed for other urban areas.

Objectives: (1) Provide a hydrologic data base to be used for verification of storm rainfall-runoff models. (2) Determine flood-volume frequency characteristics of the urban area that may be used by planners and engineers for urban storm-runoff detention and ground-water recharge studies. (3) Determine an urban rainfall-runoff model for the design and analysis of urban storm drainage and ground-water recharge systems. (4) Provide a rainfall and runoff data-collection network and quantitative model that can be utilized by future studies of water-quality characteristics of urban runoff.

Approach: The work will be completed in three phases. Phase I (FY1982-84)-The USGS has operated a network of streamflow-gaging stations in the Tucson metropolitan area for at least 10 years, and recording precipitation gages will be installed and operated to meet the objectives of this study. Phase II (FY1985 to about 1991) -Data will be collected, processed, and stored. Urban hydrology models will be calibrated and tested. Phase III-The last 2 years of the project will be for data analysis and report preparation, review, and publication.

Progress and Significant Results, Fiscal Years 1986-91: Rainfall and runoff data were collected on six watersheds. The Distributed Routing Rainfall-Runoff Model was tested using data collected on one watershed. A gaging station was reinstalled on Rob Wash after new culvert construction. The original proposal was not completely accomplished because of severe funding cuts.

Plans for Next Year: None. Funding ended. 


\section{Hydrologic Investigation of the Gila River Indian Reservation (AZ072)}

Location: Maricopa and Pinal Counties, south-central Arizona

Project Chief: B.W. Thomsen

Period of Project: May 1982 to September 1985

Cooperating Agency: Bureau of Indian Affairs

Problem: Water supplies of the Gila River Indian Reservation are affected by upstream control and diversion of surface water and nearby pumping of ground water. The reservation was established prior to the aforementioned activities; hence, information on predevelopment hydrologic conditions is needed to support Indian water-

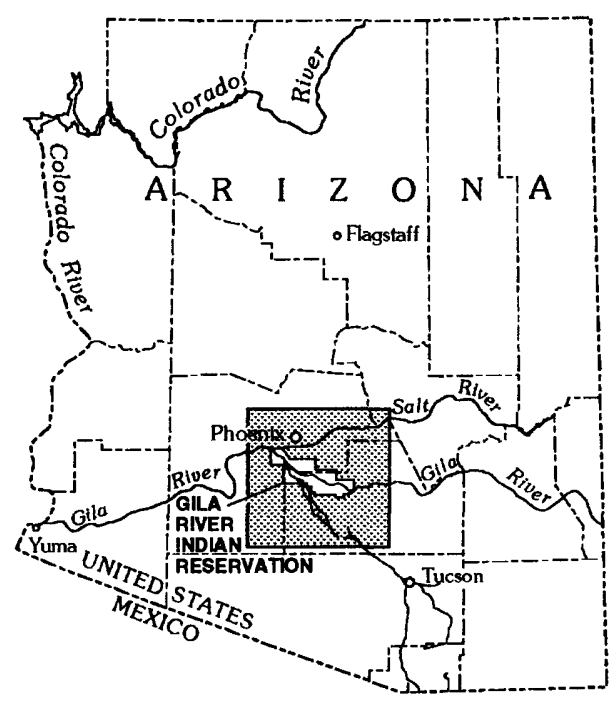
rights claims in Arizona's adjudications of water rights on the Gila River.

Objective: Construct a ground-water model of the predevelopment hydrologic system and provide documentation necessary to support Indian water-rights claims.

Approach: Collect current water-level and chemical-quality data. Develop historical and current head maps from pertinent water-level data. Establish hydrologic boundaries for which steady-state flow conditions can be reasonably estimated. Compile data on aquifer characteristics and make estimates of mountain-front recharge, evapotranspiration, and surface-water and ground-water inflows and outflows. Construct steady-state model and revise estimates as required to calibrate model.

Progress and Significant Results, Fiscal Years 1986-91: Data collection was completed in 1983 and a data report was published in 1985. Modeling was completed in 1987. Historical data indicate that the Gila River was perennial in both the east and west third of the Gila River Indian Reservation and aquifers were filled to capacity prior to development by non-Indian settlers. Mean annual flow of the Gila River upstream from the reservation was estimated to be 500,000 acre-feet, and median annual flow was estimated to be 380,000 acre-feet.

Plans for Next Year: None. Project complete.

\section{Reports:}

Thomsen, B.W., and Baldys, Stanley, III, 1985, Ground-water conditions in and near the Gila River Indian Reservation, south-central Arizona: U.S. Geological Survey Water-Resources Investigations Report 85-4073, 2 sheets. 
Thomsen, B.W., and Eychaner, J.H., 1991, Predevelopment hydrology of the Gila River Indian Reservation, southcentral Arizona: U.S. Geological Survey Water-Resources Investigations Report 89-4174, 44 p. 


\section{Effects of Vegetation Conversion on Runoff and Sediment Yields in the East Fork Sycamore Creek Drainage Basin (AZ073)}

Location: Central Arizona

Project Chief: Stanley Baldys, III

Period of Project: October 1981 to May 1986

Cooperating Agencies: Salt River Project and Forest Service

Problem: Water-resource managers are investigating methods of increasing runoff from chaparral-covered drainage basins to meet demands for water supplies for rapidly growing communities in central Arizona. Available surface-water supplies are not sufficient to meet these needs, and mining of ground-water supplies is occurring.

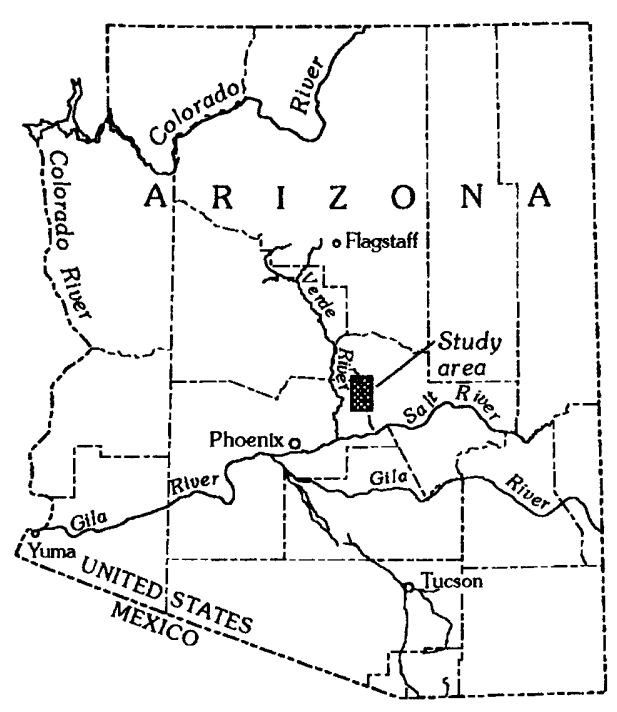

Objectives: Determine if removal of chaparral vegetation can increase runoff from a drainage basin by (1) defining the runoff and sediment-yield characteristics of dense chaparral-covered basins and (2) defining changes that take place in runoff and sediment yield as a result of the burning of the dense native chaparral in the East Fork Sycamore Creek drainage basin.

Approach: Following a controlled burn on one of two adjacent chaparral-covered drainage basins, East Fork Sycamore Creek and West Fork Sycamore Creek, streamflow gages in the basins were reactivated to determine if a change in runoff relations between the two basins occurred in response to the fire. The measured change would be based on preburn streamflow relations determined from records collected at the sites prior to the burn. Flow-activated automatic sediment samplers were installed and operated at the two streamflow gages. Precipitation gages near the center of each basin were reinstalled and operated. Spring flow, amount of channel aggradation and degradation, and amount of soil aggradation and degradation were measured at sites monitored during the preburn period. Data were collected, analyzed, and evaluated to determine if the controlled burn by the Forest Service had an effect on the runoff characteristics of the drainage basin.

Progress and Significant Results, Fiscal Years 1986-89: The controlled burn appears to have increased runoff from the burned area for a 1- to 2-year period. Increased amounts of suspended sediment also were measured during the period of increased flow. Large-scale increases were not measured and may have been missed because the burned area only covered 45 percent of the drainage basin and was in the higher altitude areas of the basin. Also, data collection did not begin until 11 months after the burn occurred.

Plans for Next Year: The water-resources investigations report is expected to be approved and published. 


\section{Hydrologic Effects of Glen Canyon Dam Operations on the Colorado River Between Glen Canyon Dam and Hoover Dam, Arizona (AZ075)}

Location: Northern Arizona

Project Chief: William B. Garrett

Period of Project: October 1982 to September 1988

Cooperating Agency: Bureau of Reclamation

Problem: The Bureau of Reclamation is in the process of uprating all the turbines at Glen Canyon Dam in order to increase the peaking discharge through the turbines. The resultant higher flows through the canyon will increase the possibility of further beach erosion and channel degradation. Uprating of the generators at Glen Canyon

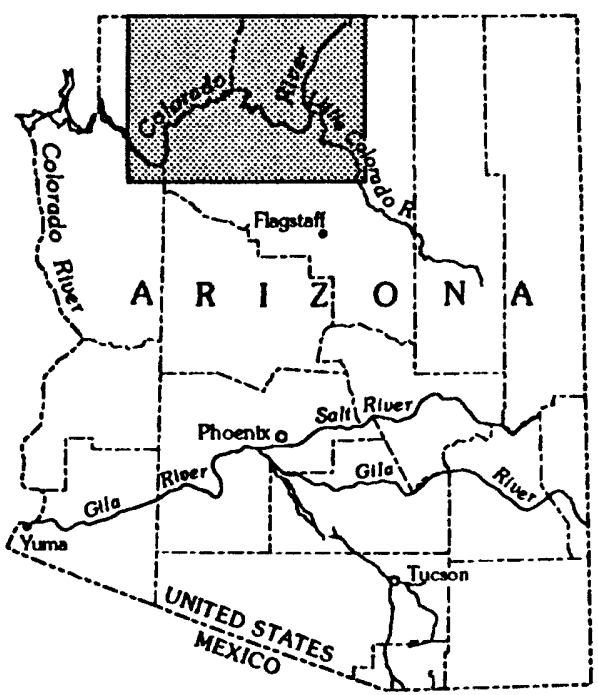
Dam will increase the capability of releasing larger volumes of water into the Colorado River. There is serious concern that the larger releases will adversely affect the environmental communities and recreational resources. Glen Canyon Dam traps essentially all the sediment load, and the clear-water releases combined with the steep gradient of the river pose a threat to alluvial material deposited prior to the dam. Removal or erosion of the alluvium poses threats to ecological and recreational resources of the Colorado River through Grand Canyon National Park.

Objectives: Collect suspended- and bedload-sediment data to monitor the effects of the present and future flow regimes at sites through the canyon and provide information so the Bureau of Reclamation can expand and refine their sediment-transport model.

Approach: Suspended-sediment, bedload-sediment, and discharge data were collected twice a day. Tributary inflow from the Paria River, Little Colorado River, and Kanab Creek also were monitored.

Progress and Significant Results, Fiscal Years 1986-1991: Streamflow and sediment-transport data were collected at five streamflow-gaging stations on the Colorado River between Glen Canyon Dam and Lake Mead. The data were used for development of unsteady flow-routing and sediment-transport models, sand-load rating curves, and evaluation of channel changes. Data were tabulated and will be presented in a U.S. Geological Survey open-file report.

Plans for Next Year: Complete and publish data report.

Webb, R.H., 1987, Debris flows from tributaries of the Colorado River, Grand Canyon National Park, ArizonaExecutive summary: U.S. Geological Survey Open-File Report 87-117, 7 p. 
1987, Occurrence of geomorphic effects of streamflow and debris flow floods in northern Arizona and southern Utah, in Mayer, L., and Nash, D., Catastrophic Flooding, v. 18: Boston, Allen \& Unwin, Inc., p. 247-265.

1987, Changes in hydrologic conditions related to large floods on the Escalante River, south-central Utah: Regional Flood Frequency Analysis, p. 309-323.

Webb, R.H., and Betancourt, J.L., 1988, Changes in variability and seasonality of flooding in southern Arizona related to general circulation and oceanic fluctuations [abs.]: Eos Transactions, American Geophysical Union, v. 69, no. 44, November 1988, p. 1220.

Webb, R.H., Pringle, P.T., Reneau, S.L., and Rink, G.R., 1988, Monument Creek debris flow, 1984-Implications for formation of rapids on the Colorado River in Grand Canyon National Park: Geology, v. 16, no. 1, p. 50-54.

Webb, R.H., Pringle, P.T., and Rink, G.R., 1989, Debris flows from tributaries of the Colorado River, Grand Canyon National Park, Arizona: U.S. Geological Survey Professional Paper 1492, 39 p. 


\section{Hydrogeology of Basin-Fill Deposits in Western Salt River Valley, Maricopa County, Arizona (AZ076)}

Location: Central Arizona

Project Chief: T.W. Anderson

Period of Project: June 1983 to September 1989

Cooperating Agencies: Arizona Department of Water Resources, Salt River Project, and Arizona Municipal Water Users' Association

Problem: Ground-water resources provide most of the water for the western Salt River Valley. Withdrawals greatly exceed recharge and therefore water levels are declining. The rate of decline is influenced by rates of

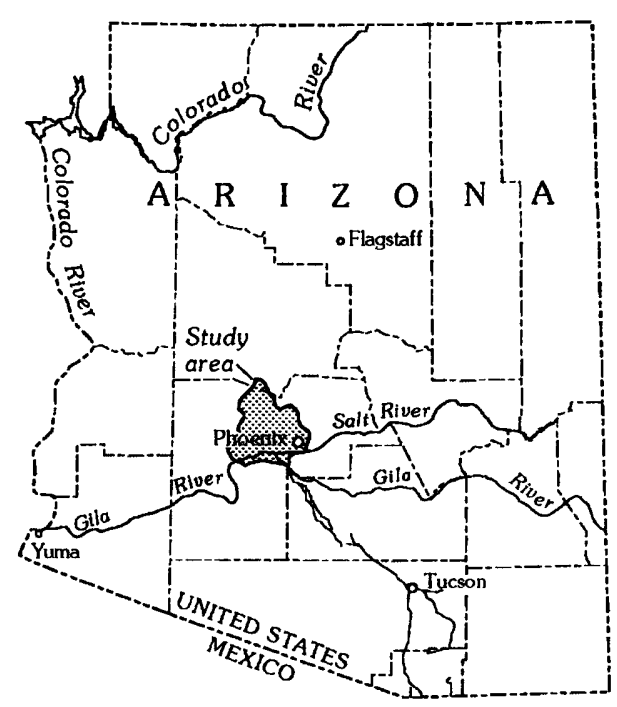
withdrawal and recharge and by the hydraulic character of the material being dewatered. Knowledge of the extent and hydraulic character of the fine-grained deposits present throughout the valley is needed in understanding the hydrogeologic framework of the aquifer.

Objectives: (1) Describe thickness, areal extent, and character of each of the major geologic units that make up the aquifer system of the study area. (2) Describe the hydraulic conductivity and specific-yield characteristics of each unit in relation to the physical properties of the materials. (3) Determine areal and vertical distributions of potential well yields and recoverable ground water in storage and describe the relations. (4) Describe ground-water quality and delineate problem area. (5) Apply information transfer techniques to complete definition of physical and hydraulic properties in data-deficient areas. (6) Develop recommendations for future data collection.

Approach: Available geophysical, lithologic, aquifer-test, specific-capacity, specific-yield, and water-quality data were collected and compiled. Information-transfer techniques were applied to test feasibility and augment information in data-deficient areas.

Progress and Significant Results, Fiscal Years 1986-89: The thickness, areal extent, and character of major lithologic units in the western part of the Salt River Valley were described. The hydraulic and water-quality characteristics of each unit also were described.

Plans for Next Year: None. Project complete.

\section{Report:}

Brown, J.G., and Pool, D.R., 1989, Hydrogeology of the western part of the Salt River Valley area, Maricopa County, Arizona: U.S. Geological Survey Water-Resources Investigations Report 88-4202, 5 sheets. 


\section{Movement of Contaminants in Ground Water, Lower Miami Wash and Pinal Creek Basins, Arizona (AZ081 and AZ082)}

Location: East-central Arizona

Project Chief: James H. Eychaner, 1984-91; James G. Brown, 1991 to present

Period of Project: April 1984 to September 1989

Cooperating Agencies: Salt River Project, U.S. Geological Survey Toxic Substances Hydrology Program, U.S. Environmental Protection Agency

Problem: An acid plume of contaminated ground water is moving in a shallow alluvial aquifer along Miami Wash and Pinal Creek, downstream from a major copper-mining district. The plume has $\mathrm{pH}$ values of 3 to 4 and large

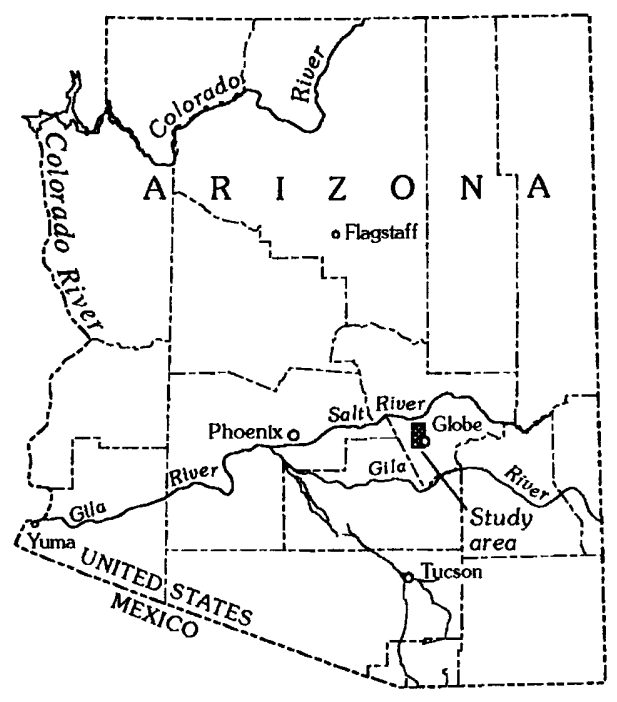
concentrations of dissolved metals. The downstream limit of contamination is unknown, but all flow in the aquifer is forced to the surface at the downstream end of the study area immediately upstream from a reservoir used for public water supply in the Phoenix metropolitan area. An estimated date of contaminant breakthrough is needed for planning management and possible mitigation measures.

Objectives: (1) Determine in three dimensions the physical extent, hydraulic characteristics, and water budget of the alluvial aquifer. (2) Determine in three dimensions the extent and chemical characteristics of the contaminant plume, uncontaminated ground water, and surface streams. (3) Estimate rates of chemical reactions that alter the chemistry of the plume. (4) Simulate the flow of ground water and surface water and the transport of chemical constituents through the study area.

Approach: Surface resistivity and seismic analyses will precede the drilling of monitoring wells along five cross sections of the aquifer. Borehole geophysical logs, aquifer material, and water samples will be collected from selected wells. Water budget will be determined with the aid of pumpage records and measurements of surface outflow and streamflow variations in Pinal Creek. Chemical analyses for major and trace elements will define the contaminated zone. Simulation of flow of water and solutes will be accomplished by a coordinated effort between the Arizona District hydrologists and National Research Program researchers in Reston and Denver.

Progress and Significant Results, Fiscal Years 1986-91: Coordinated work plan for researchers from two USGS regional centers, two EPA national laboratories, and one university was developed. Drilling through the plume was done at four sites to collect core for detailed mineralogic studies. Contaminant levels in ground water and surface water will be monitored in anticipation of plume breakthrough to perennial streamflow. Drilling, sampling, and other activities were done in coordination with other research groups using the site. 
Plans for Next Year: Prepare and publish data summary report for water year 1990-91. Prepare water-supply paper summarizing results to date. Publish water-resources investigations report to document results of ground-water flow and chemical transport.

\section{Reports:}

Brown, J.G., 1990, Chemical, geologic, and hydrologic data from the study of acidic contamination in the Miami Wash-Pinal Creek area, Arizona, water years 1988-89: U.S. Geological Survey Open-File Report 90-395, $75 \mathrm{p}$.

Eychaner, J.H., 1988, Evolution of acidic ground-water contamination in a copper-mining area in Arizona, in Ouazar, D., Brebbia, C.A., and Stout, G.E., eds., Water Quality, Planning, and Management: New York, Springer-Verlag, v. 6, Computer Methods and Water Resources, First International Conference, Morocco, 1988, Proceedings, p. 291-302.

1989, Movement of inorganic contaminants in acidic water near Globe, Arizona, in Mallard, G.E., and Ragone, S.E., eds., U.S. Geological Survey Toxic Substances Hydrology Program-Proceedings of the Technical Meeting, Phoenix, Arizona, September 26-30, 1988: U.S. Geological Survey Water-Resources Investigations Report 88-4220, p. 567-575.

1989, Research activities related to acidic water near Globe, Arizona, in Mallard, G.E., and Ragone, S.E., eds., U.S. Geological Survey Toxic Substances Hydrology Program-Proceedings of the Technical Meeting, Phoenix, Arizona, September 26-30, 1988: U.S. Geological Survey Water-Resources Investigations Report 88-4220, p. 599-601.

1991, Inorganic contaminants in acidic water near Globe, Arizona, in Survival in the Desert-Water Quality and Quantity Issues into the 21st Century: Arizona Hydrological Society, Third Annual Symposium, Casa Grande, Arizona, September 20-22, 1990, Proceedings, p. 242-252.

Eychaner, J.H., Rehmann, M.R., and Brown, J.G., 1989, Chemical, geologic, and hydrologic data from the study of acidic contamination in the Miami Wash-Pinal Creek area, Arizona, water years 1984-87: U.S. Geological Survey Open-File Report 89-410, 105 p.

Eychaner, J.H., and Stollenwerk, K.G., 1985, Neutralization of acidic ground water near Globe, Arizona, in Schmidt, K.D., ed., Symposium on groundwater contamination and reclamation, Tucson, Arizona, August 14-15, 1985, Proceedings: American Water Resources Association, August 1985, p. 141-148.

Neaville, C.C., 1989, Simulation of ground- and surface-water flow in the Globe area, Arizona, in Mallard, G.E., and Ragone, S.E., eds., U.S. Geological Survey Toxic Substances Hydrology Program-Proceedings of the Technical Meeting, Phoenix, Arizona, September 26-30, 1988: U.S. Geological Survey Water-Resources Investigations Report 88-4220, p. 577-579.

Puls, R.W., Eychaner, J.H., and Powell, R.M., 1990, Colloidal-facilitated transport of inorganic contaminants in ground water-Part 1. Sampling considerations: Ada, Oklahoma, U.S. Environmental Protection Agency, Robert S. Kerr Environmental Research Laboratory, Environmental Research Brief EPA/600/M-90/023, $12 \mathrm{p}$.

Stollenwerk, K.G., and Eychaner, J.H., 1987, Acidic ground-water contamination from copper mining near Globe, Arizona-Proceedings of the Third Technical Meeting, Pensacola, Florida, March 23-27, 1987: U.S. Geological Survey Open-File Report 87-109, p. D-19 to D-24.

1989, Solubility of aluminum and iron in ground water near Globe, Arizona, in Mallard, G.E., and Ragone, S.E., eds., U.S. Geological Survey Toxic Substances Hydrology Program-Proceedings of the Technical Meeting, Phoenix, Arizona, September 26-30, 1988: U.S. Geological Survey Water-Resources Investigations Report 88-4220, p. 581-591. 


\section{Development of an Accounting System for Water and Consumptive Use in the Lower Colorado River, Lake Mead to Mexico (AZ085)}

Location: Lower Colorado River Basin

Project Chief: Sandra J. Owen-Joyce

Period of Project: October 1984 to September 1992

Cooperating Agency: Bureau of Reclamation

Problem: Accounting for consumptive use between Hoover Dam and the international boundary with Mexico in accordance with the Supreme Court Decree of 1964 is the key problem, compounded by the concerns over the current and projected costs of administering the provisions of the Decree using the present method of determining consumptive use from

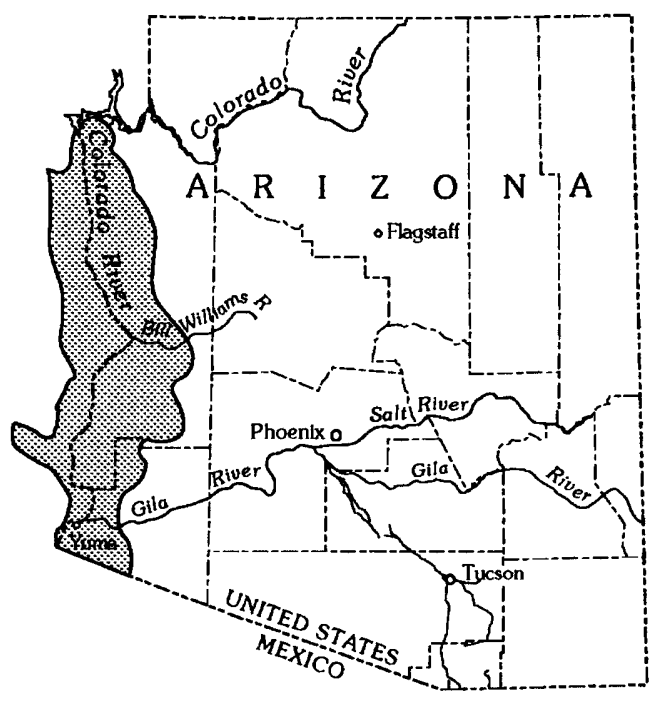
diversions and return flows. Another aspect of the Decree that is presently of great concern is the quantification of ground-water and surface-water tributary inflow. The study is needed to develop an accounting system for consumptive use using satellite imagery and a water budget.

Objectives: (1) Estimate the amount of tributary inflow for use in a water budget between Hoover Dam and the international boundary and suggest ways of incorporating tributary inflow in the process of accounting for consumptive use. (2) Develop an accounting system for consumptive use among diverters, points of diversions, and States adjacent to the lower Colorado River between Hoover Dam and the international boundary with Mexico.

Approach: (1) Obtain estimates of tributary inflow and update if necessary. (2) Develop a plan to monitor changes in tributary inflow. (3) Obtain computer equipment and programs necessary for crop identification. (4) Define parcels of land to be used in compiling amounts of consumptive use. (5) Identify test sites for periodic calibration of the method. (6) Evaluate the present surfacewater and ground-water data-collection network and modify to meet the requirements of the Decree and the new accounting system. (7) Evaluate the effect of high flows in the river on the method. (8) Develop computer program to estimate areal distribution of consumptive use and tabulate by diverter, by point of diversion, and by States. (9) Prepare a manual on the Lower Colorado River Accounting System (LCRAS) computer program and a report on the methodology.

Progress and Significant Results, Fiscal Years 1986-91: Modifications to the data-collection network along the Colorado River include elimination of six streamflow-gaging stations, installation of acoustic velocity meters at Davis and Parker Dams, and replacement of acoustic velocity meters at Hoover Dam. Seven reports and two abstracts have been published. Project was complete in 1989 except for report publication. At the request of the Bureau of Reclamation, the 
project was extended for additional work to add a single-reach option to the LCRAS program, modify the estimation of evapotranspiration by phreatophytes, and revise the water-supply paper and open-file documentation report to include these changes. The LCRAS computer program modification was completed and open-file documentation report published. LCRAS computer program was transferred to the Bureau of Reclamation in March 1990. The water-supply paper was rewritten and is pending Director's approval.

Plans for next year: Completion and publication of the reports (1) "An accounting system for water and consumptive use along the Colorado River, Hoover Dam to Mexico," by Sandra J. Owen-Joyce and Lee H. Raymond (U.S. Geological Survey Water-Supply Paper) and (2) "Lower Colorado River Accounting System (LCRAS)," by Sandra J. Owen-Joyce (U.S. Geological Survey Open-File Report: Fact Sheet).

\section{Reports:}

Owen-Joyce, S.J., 1987, Estimates of average annual tributary inflow to the lower Colorado River, Hoover Dam to Mexico: U.S. Geological Survey Water-Resources Investigations Report 87-4078, 1 sheet.

1988, Estimates of consumptive use and ground-water return flow using water budgets in Parker Valley, Arizona and California, 1981-84: U.S. Geological Survey Water-Resources Investigations Report $88-4063,64 \mathrm{p}$.

1990, Accounting for water use along the Colorado River, Hoover Dam to Mexico, in Minimizing Risk to the Hydrologic Environment: American Institute of Hydrology, 1990 Spring Meeting, Program with Abstracts, Las Vegas, Nevada, March 12-16, 1990, p. 22.

1990, Estimates of consumptive use and ground-water return flow and the effect of rising and sustained high river stage on the method of estimation in Cibola Valley, Arizona and California, 1983 and 1984: U.S. Geological Survey Water-Resources Investigations Report 89-4194, 41 p.

Owen-Joyce, S.J., and Kimsey, S.L., 1987, Estimates of consumptive use and ground-water return flow using water budgets in Palo Verde Valley, California: U.S. Geological Survey Water-Resources Investigations Report $87-4070,50 \mathrm{p}$.

Owen-Joyce, S.J., and von Allworden, B.K., 1990, Water-budget and remote-sensing technologies combine to account for water use along the lower Colorado River, in Balthrop, B.H., and Baker, E.G., 1990, U.S. Geological Survey, National Computer Technology Meeting, Program and Abstracts, San Antonio, Texas, May 7-11, 1990: U.S. Geological Survey Open-File Report 90-161, p. 27.

Raymond, L.H., and Owen-Joyce, S.J., 1986, Estimates of consumptive use and evapotranspiration in Palo Verde Valley, California, 1981 and 1983, in Johnson, A.I., and Rango, A., eds., Remote Sensing Applications for Consumptive Use (Evapotranspiration): American Water Resources Association Monograph Series 6, p. 25-34.

1987, Comparison of estimates of evapotranspiration and consumptive use in Palo Verde Valley, California: U.S. Geological Survey Water-Resources Investigations Report 87-4071, 27 p.

von Allworden, B.K., Owen-Joyce, S.J., Sandoval, J.D., and Raymond, L.H., 1991, Lower Colorado River Accounting System (LCRAS) computer program and documentation: U.S. Geological Survey Open-File Report 91-179, 237 p. 


\section{Development of Techniques for the Prediction of Land Subsidence Due to Ground-Water Withdrawal (AZ086)}

Location: South-central Arizona (Topical research)

Project Chief: Stanley A. Leake

Period of Project: October 1984 to September 1992

Cooperating Agency: Regional Aquifer-System Analysis Program (U.S. Geological Survey Federal Program)

Problem: Ground-water withdrawals that exceed natural recharge have resulted in compaction of sediments and land subsidence in many areas. Methodology for studying land subsidence with predictive models is available but is not readily applicable by practicing geohydrologists. Development of practical predictive tools is needed.

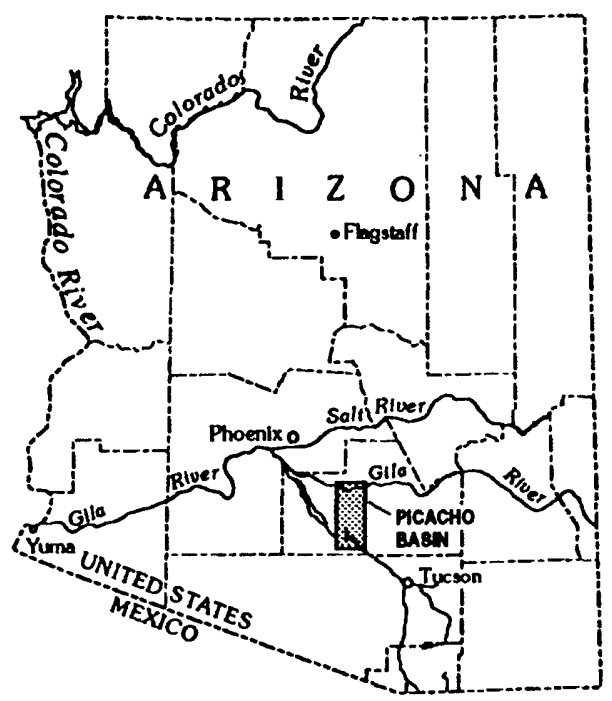

Objectives: Develop quantitative techniques for prediction of land subsidence caused by groundwater withdrawal in alluvial basins and similar geohydrologic environments.

Approach: The primary field site for evaluating methodology is the Picacho basin of southcentral Arizona where as much as $15 \mathrm{ft}$ of land subsidence has been measured. A ground-water model for the basin will be developed. Literature searches for applicable predictive techniques will be conducted. Previously developed land-subsidence algorithms will be employed to test for applicability to the particular lithologic environment. Transferability of these existing techniques to other geohydrologic environments will be studied. The theoretical basis for application of multidimensional stress-strain theory to prediction of land subsidence in alluvial basins will be studied.

Progress and Significant Results, Fiscal Years 1986-91: Three methods of simulating land subsidence in ground-water flow models were developed and tested. The first method incorporates the following assumptions: a unit decline in ground-water level is assumed to equal a unit increase in effective stress, delay in release of water from compressible interbeds is negligible, and the values of elastic and inelastic specific storage are constant. The second method differs from the first method only in that delay in release of water need not be negligible. The third method incorporates the assumption that delay in release of water from compressible interbeds is negligible. However, geostatic load may vary as a function of water level, values of elastic and inelastic specific storage may vary with changes in effective stress, and the total thickness of compressible interbeds may vary as a function of saturated thickness of the aquifer. This method is appropriate for simulating land subsidence in shallow water-table aquifers. All three methods were tested in a model of ground-water flow in Picacho basin. The first method was documented 
in a Techniques of Water-Resources Investigations Report for general use with the U.S. Geological Survey finite-difference ground-water model program.

\section{Plans for Next Year: Complete reports.}

\section{Reports:}

Carpenter, M.C., 1987, Water-level declines, land subsidence, and specific compaction near Apache Junction, south-central Arizona: U.S. Geological Survey Water-Resources Investigations Report 86-4071, 22 p.

1988, Land-surface deformation and water-level fluctuations near the Picacho earth fissure, south-central Arizona, 1980-84: U.S. Geological Survey Open-File Report 88-97, 24 p.

1989, Earth-fissure movements associated with fluctuations in ground-water levels, south-central Arizona, 1980-84 [abs.]: 28th International Geological Congress, Washington, D.C., July 9-19, 1989, Abstracts, v. 1, p. 243.

1991, Earth-fissure movements associated with fluctuations in ground-water levels near the Picacho Mountains, south-central Arizona, 1980-84: U.S. Geological Survey Open-File Report 90-561, 64 p.

Carpenter, M.C., Hanson, R.T., and Riley, F.S., 1987, An averaging temperature sensor to correct measurements of aquifer compaction for interaquifer borehole flow [abs.]: Eos Transactions, American Geophysical Union, v. 68 , no. 44 , November 3,1987 , p. 1300.

Epstein, V.J., 1987, Hydrologic and geologic factors affecting land subsidence near Eloy, Arizona: U.S. Geological Survey Water-Resources Investigations Report 87-4143, 28 p.

Leake, S.A., 1989, New approaches to simulating aquifer-system compaction in models of regional ground-water flow: 28th International Geological Congress, Washington, D.C., July 9-19, 1989, Abstracts, v. 2, p. 271-272.

1990, Applications of user-supplied transformations in computer-graphics programs, in Wiltshire, D.A., Selected Papers in the Applied Computer Sciences, 1990: U.S. Geological Survey Bulletin 1908, p. A1-A5.

1990, Interbed storage changes and compaction in models of regional groundwater flow: Water Resources Research, v. 26, no. 9, p. 1939-1950.

1990, Interbed storage changes and compaction in models of regional groundwater flow [abs.]: Eos Transactions, American Geophysical Union, v. 71, no. 19, May 8, 1990, p. 704.

1991, Application of user-supplied transformations in computer-graphics programs [abs.], in Balthrop, B.H., and Terry, J.E., eds., U.S. Geological Survey National Computer Technology Meeting-Proceedings, Phoenix, Arizona, November 14-18, 1988: U.S. Geological Survey Water-Resources Investigations Report 90-4162, p. 73.

1991, Simulation of vertical compaction in models of regional ground-water flow, in Johnson, Ivan, ed., Land Subsidence-Proceedings of the Fourth International Symposium on Land Subsidence, Houston, Texas, May 1991: International Association of Hydrological Sciences Publication No. 200, p. 565-574.

Leake, S.A., and Prudic, D.E., 1987, New approaches to simulating aquifer-system compaction in models of regional ground-water flow [abs.]: Eos Transactions, American Geophysical Union, v. 68, no. 44, November 3, 1987, p. 1301.

Leake, S.A., and Prudic, D.E., 1991, Documentation of a computer program to simulate aquifer-system compaction using the modular finite-difference ground-water flow model: U.S. Geological Survey Techniques of Water-Resources Investigations, book 6, chap. A2, 68 p.

Pool, D.R., 1989, Estimation of aquifer-system storage properties in an alluvial basin, south-central Arizona: 28th International Geological Congress, Washington, D.C., July 9-19, 1989, Abstracts, v. 2, p. 623. 


\section{Reconnaissance Investigations of the Hydrologic System in the San Bernardino Valley, Southeast Arizona (AZ088)}

Location: Southeastern Arizona

Project Chief: T.W. Anderson, 1985-90;

Steve A. Longsworth, 1990-91

Period of Project: January 1985 to September 1988

Cooperating Agency: Fish and Wildlife Service

Problem: The Fish and Wildlife Service has established a 2,500-acre refuge in southern San Bernardino Valley. The refuge contains a unique wetlands habitat for many species of wildlife, including an endangered species of fish, the Yaqui Topminnow. Information on the reliability of the water supply, including the effects of nearby ground-water withdrawal in the United States and Mexico, is needed for

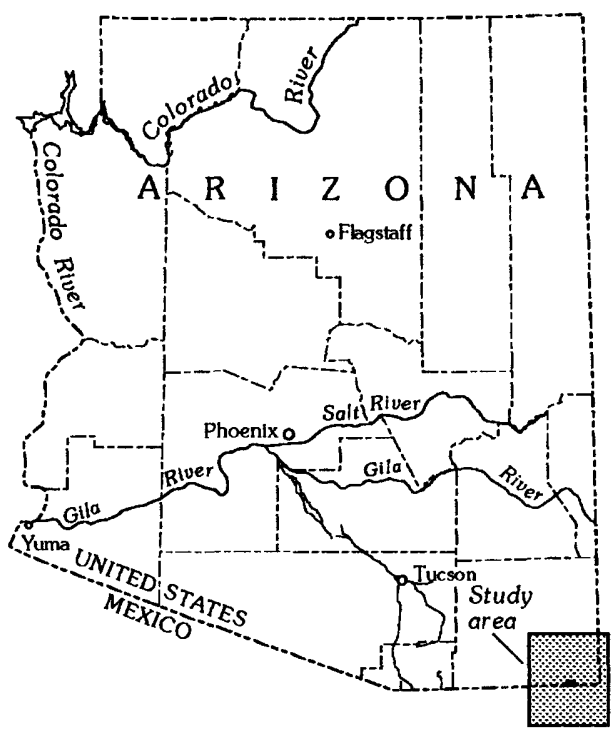
proper management of the refuge and for the proper protection of the fish.

Objectives: The general objective was to develop a basic understanding of the hydrologic system near the refuge that would allow a qualitative prediction of system response to developmental stresses. Other objectives included evaluation of flow rates and hydraulic heads and their temporal fluctuations on the refuge, determination of water quality, description of geohydrology, and evaluation of the hydraulic properties of the system.

Approach: This investigation was designed to allow a four-phase, intermittently funded approach. First, data inventory and collection included well and spring inventory, geologic reconnaissance, water-sample collection, and measurement of field hydraulic parameters. Second, system monitoring included monitoring of flows and heads in selected springs and wells and periodic water-quality sampling. Third, data analyses included mapping of head distributions, evaluation of field data, and subsequent evaluation of the aquifer system. Fourth, the results of the study were documented in a water-resources investigations report.

Progress and Significant Results, Fiscal Years 1986-91: The hydrologic system in the San Bernardino National Wildlife Refuge provides an adequate ground-water supply for restoration and maintenance of the unique wetlands habitat for fish and wildlife. Surface-water supplies in the area are sparse and unreliable, and thus habitat restoration and protection depend on the availability of a reliable supply of ground water of acceptable chemical quality. Results of field investigation pertaining to geology, water quality, aquifer hydraulics, and water use indicate that an adequate supply of good-quality water is available under existing hydrologic conditions. Small quantities of artesian flow are available from nine wells, and small pumps could be used to increase water 
quantity for short-term demands. The total effects of environmental stresses on the ground-water system, however, cannot be evaluated on the basis of available data. Further studies involving additional data-collection activities, including data on well-discharge rates, ground-water quality, and pumpage in areas near the refuge, could provide information necessary for a more accurate evaluation of the hydrologic system.

Plans for Next Year: None. Project complete.

\section{Report:}

Longsworth, S.A., 1991, Geohydrology and chemical quality of ground water, San Bernardino National Wildlife Refuge, Arizona: U.S. Geological Survey Water-Resources Investigations Report 90-4190, 28 p. 


\section{Hydrology of the Salt River Indian Reservation (AZ089)}

Location: South-central Arizona

Project Chief: B.W. Thomsen

Period of Project: May 1985 to September 1988

Cooperating Agency: Bureau of Indian Affairs

Problem: Arizona has initiated efforts directed toward comprehensive basinwide water-rights adjudications covering the Gila River watershed. Federal courts have ruled that the McCarran Amendment applies to these adjudications; thus, all water-rights claimants, including Federal agencies and Indian tribes, would be included in

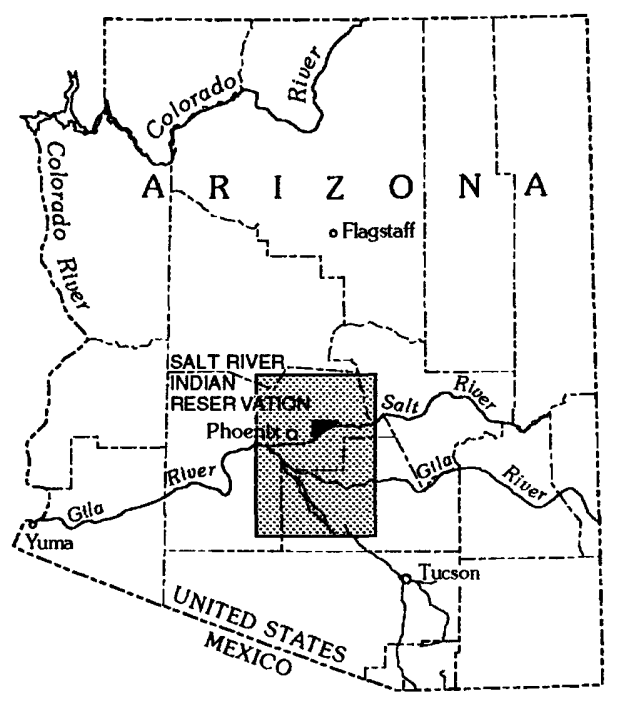
these proceedings. Water supplies of the Salt River Indian Reservation are affected by developmental activities such as upstream control and diversion of surface flows and nearby pumping interference and (or) possible capture of ground water. Verification and documentation of the hydrologic conditions that existed prior to the aforementioned developmental activities are needed to support Indian claims.

Objectives: Prepare a mathematical representation of the historical (predevelopment) hydrologic system and provide the documentation needed to support the Indian water-rights claims. Information on the chemical quality of the water in both the historical and current hydrologic systems will be important to the settlement of the claims.

Approach: Collect all available data. Conduct a well inventory and collect water samples. Measure water levels during winter of 1985-86. Develop a steady-state and current water-level map. Estimate surface-water and ground-water inflows and outflows under steady-state conditions. Make estimates of natural areal and mountain-front recharge to the aquifer system. Establish hydrologic boundaries for which steady-state flow conditions can be reasonably estimated and select grid size to be used in the model. Construct a steady-state model using preliminary estimates of hydraulic properties and flow quantities. Revise estimates, if necessary, and collect additional data as required. Calibrate steady-state model.

Progress and Significant Results, Fiscal Years 1986-91: Predevelopment hydrologic conditions in the Salt River Valley were investigated to provide information for the adjudication of water rights of users in the Gila River basin. A ground-water flow model was developed to simulate ground-water flow, riverbed infiltration, mountain-front recharge, and evapotranspiration to evaluate predevelopment ground-water conditions. Annual average values for components of 
ground-water flow determined from the model for the study area include recharge by infiltration from the Salt River, 19,700 acre-feet; mountain-front recharge and subsurface inflow, 10,700 acrefeet; discharge to the Salt River near Tempe, 9,800 acre-feet; evapotranspiration from ground water, 13,300 acre-feet; and subsurface outflow, 7,300 acre-feet.

Plans for Next Year: None. Project complete.

\section{Reports:}

Thomsen, B.W., and Miller, B.H., 1991, Ground-water conditions in and near the Salt River Indian Reservation, south-central Arizona: U.S. Geological Survey Water-Resources Investigations Report 89-4176, 2 sheets.

Thomsen, B.W., and Porcello, J.J., 1991, Predevelopment hydrology of the Salt River Indian Reservation, East Salt River Valley, Arizona: U.S. Geological Survey Water-Resources Investigations Report 91-4132, 37 p. 


\section{Evaluation of Recharge along the Gila River as a Result of the October 1983 Flood (AZ090)}

Location: South-central Arizona

Project Chief: Steven R. Anderson, 1986-89; Alice D. Konieczki, 1989-90

Period of Project: May 1985 to September 1989

Cooperating Agency: Bureau of Indian Affairs

Problem: Changes in ground-water levels occurred along the Gila River in response to the infiltration of surface water during the flood of October 1983. Data collected before and after the flood may allow evaluation of the system response and quantification of the recharge. Such information is vital to the successful management of water

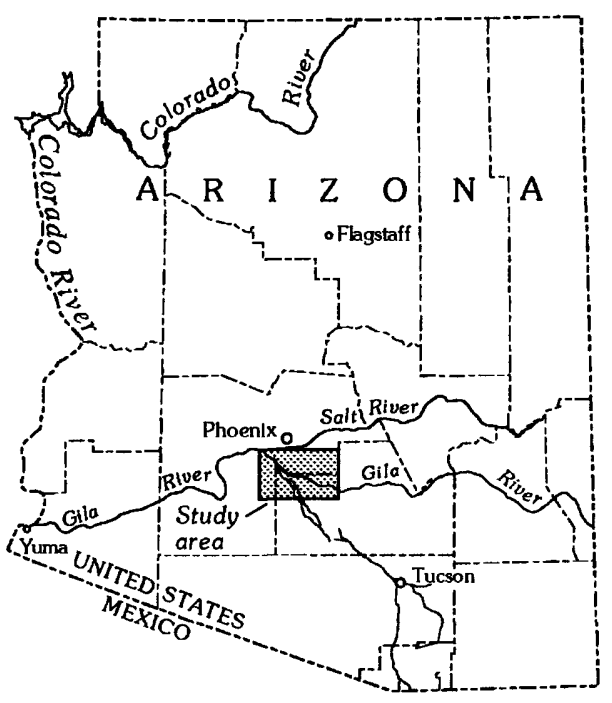
resources in the affected area.

Objective: Document the effects of recharge on the ground-water system along the flood plain of the Gila River between Ashurst-Hayden Dam and the Salt River confluence.

Approach: Relate documented ground-water system response to local geologic conditions, depth to water, distance from the area of recharge, time since recharge occurred, and other factors as feasible. Relate the magnitude of surface flow and estimated ground-water recharge in order to illustrate the significance of this type of flood in relation to the ground-water budget of the area and the total volume of ground water in storage.

Progress and Significant Results, Fiscal Years 1986-90: A water-budget method and a waterlevel change method were used to estimate the recharge from January 1983 through March 1984 along the Gila River from Ashurst-Hayden Dam to the confluence with the Salt River. Estimates of the recharge from January 1983 to March 1984 range from 449,000 to 640,000 acre-feet; at least 46 to 66 percent of the increase was the result of streamflow infiltration from the Gila River during October 1983 to March 1984. Water-level rises during the period also may have been affected by reduced pumping, canal seepage, irrigation return flow, and streamflow infiltration from the Santa Cruz River.

Plans for Next Year: None. Project complete.

\section{Report:}

Konieczki, A.D., and Anderson, S.R., 1990, Evaluation of ground-water recharge along the Gila River as a result of the flood of October 1983, in and near the Gila River Indian Reservation, Maricopa and Pinal Counties, Arizona: U.S. Geological Survey Water-Resources Investigations Report 89-4148, 30 p. 


\section{Lyman Lake Water Budget (AZ092)}

Location: Lyman Lake area, northern Arizona

Project Chief: Donald J. Bills

Period of Project: March 1985 to September 1987

\section{Cooperating Agency: Salt River Project}

Problem: Lyman Lake, an irrigation-storage reservoir, was built on the upstream edge of a large spring area that is a major discharge area for the regional Coconino aquifer. It is suspected that the reservoir is a net contributor of water to the Coconino aquifer during high stages and a net gainer during low stages. Ground-water pumping will increase greatly during the next few years as

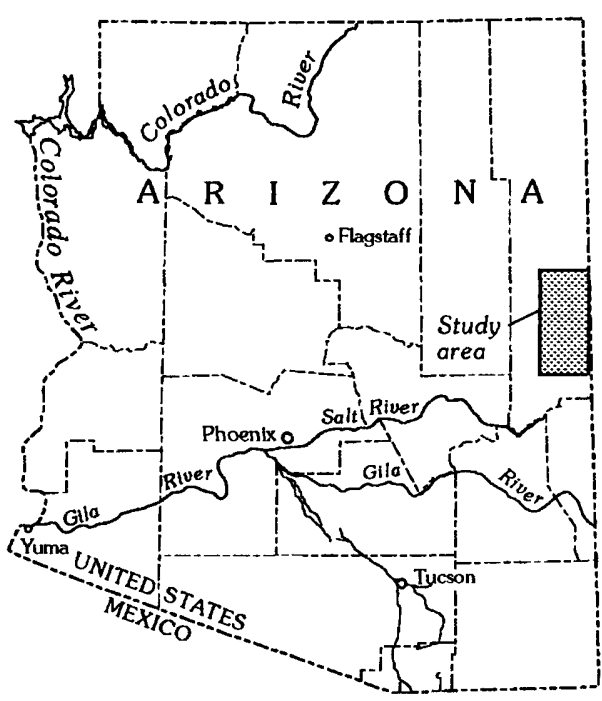
two coal-fired electric-generating plants are brought on line. These plants will require a combined total of about 23,000 acre-feet per year of ground water and will have an effect on the regional aquifer underlying the study area as well as on the surface-water system in the area by reducing spring flow and possibly by intercepting streamflow and impounded irrigation water.

Objectives: Verify and quantify a suspected surface-water and ground-water relation for a short reach of the Little Colorado River encompassing Lyman Lake and Salado Springs using a monthly water budget as the primary investigative method.

Approach: Develop a monthly water budget and explore the possibility of interaction between the water in Lyman Lake and the surrounding aquifer by (1) estimating monthly surface flow to and from the area using records of spring flow, streamflow, and precipitation; (2) producing a continuous stage-record and stage-capacity table for Lyman Lake; (3) determining monthly evaporation rates from the lake; (4) determining flow of Salado Springs; (5) determining interrelation of lake stage, spring flow, and ground-water levels; and (6) collecting and analyzing selected water samples for possible identification of sources of water in the area.

Progress and Significant Results, Fiscal Years 1986-89: Surface-water and ground-water resources were defined quantitatively by the use of water budgets and geochemical data. Groundwater flow to and from Lyman Lake was computed using water budgets. During the study period, ground-water flow from the lake was estimated to be about 6 percent of the total water budget of the lake, which was about 84 acre-feet, for the budget period. Chemical and deuterium data indicate that as much as 5 percent of ground-water flow to the Little Colorado River between Lyman Dam and Salado Springs may originate as lake seepage. Chemical and isotope data show that the aquifer contributes about 36 to 41 percent of the water in the river in the spring area. 
Plans for Next Year: None. Project complete.

\section{Reports:}

Bills, D.J., and Hjalmarson, H.W., 1990, Estimates of ground-water flow components for Lyman Lake, Apache County, Arizona, with a section on Geochemistry of surface water and ground water in the Lyman Lake area, by F.N. Robertson: U.S. Geological Survey Water-Resources Investigations Report 89-4151, 55 p.

Hjalmarson, H.W., and Robertson, F.N., 1991, Hydrologic and geochemical approaches for determining ground-water flow components, in Ritter, W.F., ed., Irrigation and Drainage, Proceedings of the 1991 National Conference: New York, American Society of Civil Engineers, p. 267-274. 


\section{Estimation of Salinity Loads, Colorado River from Imperial Dam to Southerly International Boundary (AZ093)}

Location: Lower Colorado River

Project Chief: Scott M. Knowles, 1986-88;

Brian K. von Allworden, 1988-91

Period of Project: October 1984 to September 1986

Cooperating Agency: Bureau of Reclamation

Problem: Salinity concentrations in the Colorado River are highly correlated with water-use, agriculture, municipal, and industrial development; transbasin diversions; and natural sources, especially droughts and floods. To fulfill management responsibilities, the Bureau

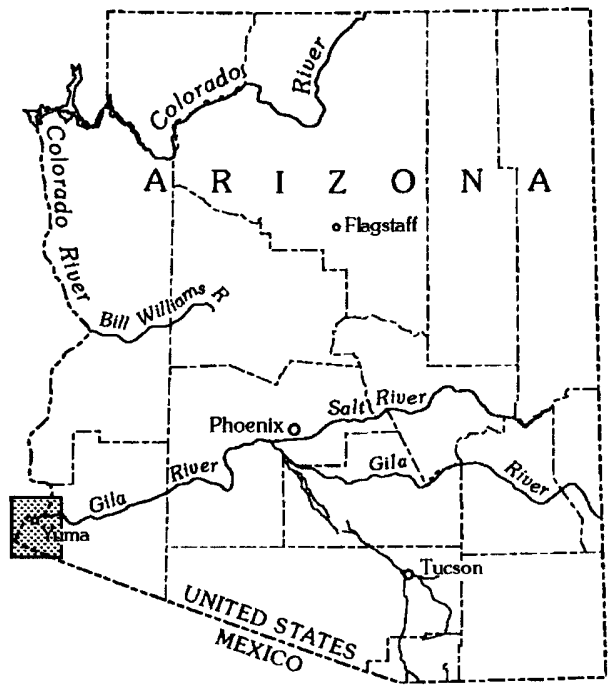
of Reclamation must determine the degree to which the salinity concentrations are affected by management decisions. A tool in the management of the river is a data base of sufficient duration that will allow for projections of flows and salinities to some point in the future.

Objective: Develop a data base of monthly discharges and salinity loads for 1935 to current year, or as appropriate, for selected sites on the Colorado River from Imperial Dam to the southerly international boundary. This includes estimating monthly salinity loads and monthly flow data wherever data are missing and documenting procedures used to estimate them.

Approach: The availability and completeness of flow records and water-quality records were determined at those stations listed in the location section, and data were entered in the data base. Using appropriate statistical programs, techniques were developed to fill in missing periods of record for flow and salinity. If daily discharge and (or) conductivity data were available for the missing period, the salinity loads were estimated using the relation between discharge and salinity, or conductivity and salinity, whichever was appropriate. Data used to develop the relation were collected from periods similar to those being estimated. Estimating techniques may have differed for each site.

Progress and Significant Results, Fiscal Years 1986-91: Report is in the review process. Project is complete except report.

Plans for next year: Complete review process and publish report. 


\section{Stability of Alluvial Sand Bars, Colorado River in Grand Canyon National Park (AZ095)}

Location: Northeastern Arizona

Project Chief: Julia B. Graf

Period of Project: October 1985 to September 1990

Cooperating Agency: Bureau of Reclamation

Problem: Alluvial sand bars along the margins of the Colorado River in Grand Canyon National Park between Glen Canyon Dam and Lake Mead are composed primarily of fine to medium sand. Some bars are heavily vegetated and provide important habitat for wildlife, whereas others are unvegetated and are used as campsites by Canyon visitors. Regulation of flow at Glen Canyon dam has

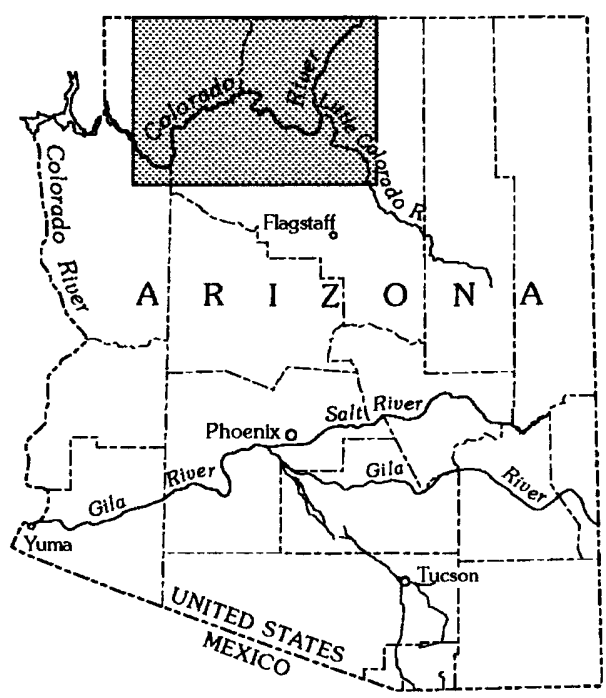
significantly reduced peak discharge and has provided strong daily fluctuations in discharge. These changes, coupled with the loss of the sediment supply from upstream of the dam, have caused concern that sand bars may be undergoing net erosion and may eventually be removed entirely.

Objectives: Identify the physical conditions and processes that control sand-bar changes along the Colorado River in Grand Canyon National Park and relate the location and magnitude of bar changes to flow in the main channel. A quantitative relation between sand-bar change and operating regime of Glen Canyon Dam will be developed if possible.

Approach: The nature and cause of sand-bar change will be investigated in two phases. In phase one, long-term changes will be documented and systematized by examination of available photographs and surveys. Changes will be related to values of geomorphic variables measured from photographs or in the field. Sand-bar changes will be examined in relation to known changes in water and sediment discharge over similar periods. In phase two, processes currently acting on the sand bars will be identified and quantified so that short-term changes can be related to different regulation regimes, and general aspects of sand erosion, transport, and deposition can be understood.

Progress and Significant Results, Fiscal Years 1986-91: A classification of sand bars was developed that relates form and location of bars to controlling factors. A qualitative rating of susceptibility to erosion of sand-bar types also was developed. The project provided the information required for formulation of a conceptual model for sand-bar response to flow. A network of camping beaches that will serve for monitoring of long-term changes in sand bars and vegetation was selected and documented. 
Plans for Next Year: Investigation of eddy processes and sand-bar response will continue under "Grand Canyon Beach Evolution" (AZ120) in which the conceptual model of bar change and information on sand-bar response will be integrated with an ongoing effort to develop mathematical models for eddy zones. Processes in eddy zones will be linked to flow and sediment transport in the main channel being investigated in "Grand Canyon Sediment Transport" (AZ121).

\section{Reports:}

Graf, J.B., Kieffer, S.W., and Schmidt, J.C., 1989, Hydraulic log of the Colorado River from Lees Ferry to Diamond Creek, Arizona-Chapter 2, in Elston, D.P., Billingsly, G.H., and Young, R.A., eds., Geology of Grand Canyon, Northern Arizona: American Geophysical Union, Field Guide for the 28th International Geological Congress, Washington, D.C., July 1989, p. 37-47.

Graf, J.B., Pemberton, E.L., and Schmidt, J.C., 1986, Sediment studies in Grand Canyon, Arizona: Fourth Federal Interagency Sedimentation Conference, v. 2, Las Vegas, Nevada, March 24-27, 1986, Proceedings, p. 5-61 to 5-70.

Gray, J.R., Webb, R.H., and Hyndman, D.W., 1991, Low-flow sediment transport in the Colorado River, in Fan, Shou-Shan, and Kuo, Yung-Huang, eds., Proceedings of the Fifth Federal Interagency Sedimentation Conference, Las Vegas, Nevada, March 18-21, 1991: Washington, D.C., Federal Energy Regulatory Commission, v. 1, p. 4-63 to 4-71.

Hyndman, D.W., Roberts, R.A., and Webb, R.H., 1991, Modeling sediment transport in an ephemeral river, in Fan, Shou-Shan, and Kuo, Yung-Huang, eds., Proceedings of the Fifth Federal Interagency Sedimentation Conference, Las Vegas, Nevada, March 18-21, 1991: Washington, D.C., Federal Energy Regulatory Commission, v. 2, p. 8-101 to 8-108.

Kieffer, S.W., Graf, J.B., and Schmidt, J.C., 1989, Hydraulics and sediment transport of the Colorado River: Chapter 3, in Elston, D.P., Billingsly, G.H., and Young, R.A., eds., Geology of Grand Canyon, Northern Arizona: American Geophysical Union, Field Guide for the 28th International Geological Congress, Washington, D.C., July 1989, p. 48-66.

Schmidt, J.C., 1986, Controls on flow separation and sedimentation in a bedrock river, Colorado River, Grand Canyon, Arizona: Geological Society of America, Abstracts with Programs, v. 18, p. 741.

Schmidt, J.C., and Graf, J.B., 1987, Response of eddy-system deposits to dam operations, Colorado River, Grand Canyon National Park, Arizona [abs.]: Eos Transactions, American Geophysical Union, v. 67, no. 44, November 4, 1986, No. H41A-05, p. 950.

1988, Aggradation and degradation of alluvial sand deposits, 1965 to 1986, Colorado River, Grand Canyon National Park, Arizona-Executive summary: U.S. Geological Survey Open-File Report 87-561, $15 \mathrm{p}$.

1990, Aggradation and degradation of alluvial sand deposits, 1965 to 1986, Colorado River, Grand Canyon National Park, Arizona: U.S. Geological Survey Professional Paper 1493, 74 p.

Wilson, R.P., 1986, Sonar patterns of Colorado River bed, Grand Canyon: Fourth Federal Interagency Sedimentation Conference, v. 2, Las Vegas, Nevada, March 24-27, 1986, Proceedings, p. 5-133 to 5-142. 


\section{Moisture and Solute Movement in the Unsaturated Zone in Response to Natural and Artificial Recharge (AZ096)}

Location: Tucson, Arizona

Project Chief: David D. Graham

Period of Project: October 1985 to September 1988

Cooperating Agency: City of Tucson

Problem: The City of Tucson proposed to use artificial recharge of tertiary-treated effluent as a means of conserving water and also as a means of storing water imported into the Tucson basin for withdrawal during periods of high demand. A demonstration site consisting of four 3/4-acre recharge basins was built on the flood

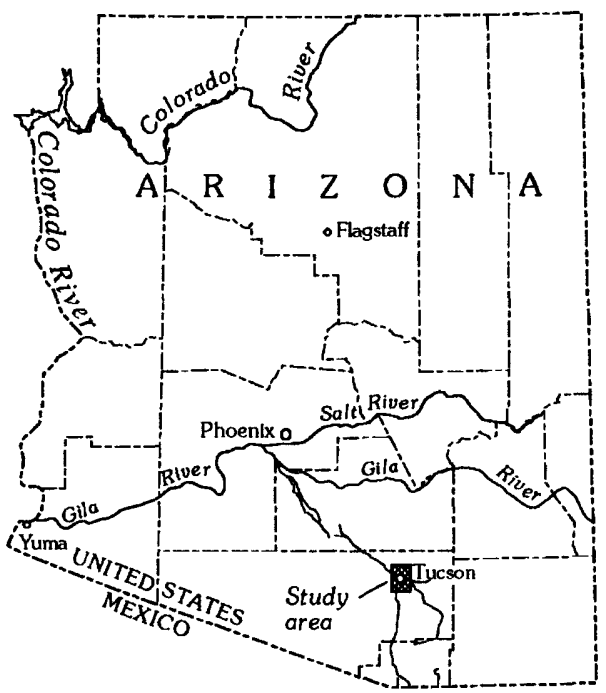
plain of the Santa Cruz River. Field-determined information on the movement of moisture and the associated attenuation, exchange, and dispersion of dissolved chemical constituents through the unsaturated zone was needed for informed planning of future recharge facilities.

Objectives: (1) Monitor spatial and temporal changes in water content of the unsaturated zone and the movement of dissolved chemical constituents. (2) Make estimates of the horizontal and vertical dispersion characteristics of the heterogeneous sediments in the unsaturated zone. (3) Provide field-determined values needed for calibrating and verifying numerical models.

Approach: An array of about 20 access tubes was installed at the artificial-recharge demonstration site and monitored using neutron-logging techniques to determine moisture-content changes in the unsaturated zone in response to natural and artificial recharge. The movement of a tracer was monitored using samples collected from porous-cup pressure-vacuum lysimeters installed at depths that range from 11 to $45 \mathrm{ft}$ below the bottom of a recharge basin. Breakthrough curves were analyzed to determine the mechanism of flow that controls solute transport.

Progress and Significant Results, Fiscal Years 1986-90: The results of the tracer test indicate that solute movement through the poorly sorted stratified alluvial sediments in the unsaturated zone beneath the basin takes place along preferential flow paths. Velocity of solute flow computed from time of first tracer arrival ranged from 1.9 to 9.0 feet per day.

Plans for Next Year: None. Project complete. 


\section{Reports:}

Graham, D.D., 1988, Flow in the unsaturated zone, Tucson, Arizona: U.S. Geological Survey Open-File Report 88-329, Water Fact Sheet, 1 sheet.

1989, Methodology, results, and significance of an unsaturated-zone tracer test at an artificial-recharge facility, Tucson, Arizona: U.S. Geological Survey Water-Resources Investigations Report 89-4097, 28 p.

1990, Unsaturated-zone tracer test at an artificial-recharge facility, Tucson, Arizona, in Minimizing Risk to the Hydrologic Environment: American Institute of Hydrology, 1990 Spring Meeting, Program with Abstracts, Las Vegas, Nevada, March 12-16, 1990, p. 19.

1991, Results and significance of an unsaturated-zone tracer test at an artificial-recharge basin, Tucson, Arizona [abs.]: Phoenix, Salt River Project, Fifth Biennial Symposium on Artificial Recharge of Groundwater, Tucson, Arizona, May 29-31, 1991, Proceedings, p. 169. 


\section{Irrigation Drainage Quality in the Lower Colorado River Valley (AZ097)}

Location: Lower Colorado River valley, Arizona, California, and Nevada

Project Chief: Dean B. Radtke

Period of Project: September 1985 to September 1987

Cooperating Agencies: Fish and Wildlife Service, Bureau of Reclamation, Bureau of Indian Affairs, and Bureau of Land Management

Problem: Concern had increased about the quality of irrigation drainage and its potential effects on humans, fish, and wildlife. The lower Colorado River valley area was selected for study because sufficient information existed to indicate that potential contamination problems existed.

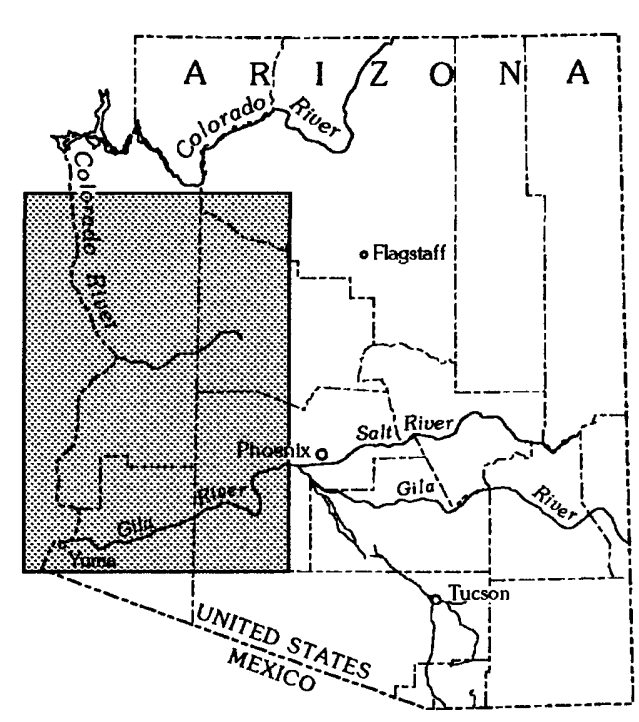

Objective: Determine from existing data and reconnaissance field sampling whether irrigation-drainage waters have caused or have the potential to cause harmful effects on humans, fish, and wildlife or reduce suitability of water for other uses.

Approach: Water, bottom material, and plant and animal tissues were collected and analyzed for trace element and organic contaminants. The study focused on irrigation and drainage facilities constructed or managed by the Department of the Interior (DOI), national wildlife refuges managed by DOI, and other migratory bird or endangered species management areas that receive water from DOI-funded projects.

Progress and Significant Results, Fiscal Years 1986-90: Except for selenium and DDE, sampling locations were found to be relatively free of large concentrations of selected toxic inorganic and synthetic organic constituents that could be a threat to humans, fish, and wildlife. Mean selenium concentrations in fish-tissue samples at all sites exceeded the 85-percent national baseline for fish. The concentrations appeared to be derived from other sources and not from agricultural practices in the study area.

Plans for Next Year: None. Project complete.

\section{Reports:}

Kepner, W.G., Hunter, W.C., Eddleman, W.R., and Radtke, D.B., 1990, Selenium bioaccumulation in Yuma clapper rail and other rallids from the lower Colorado River valley [abs.], in Joint Annual Meeting of American 
Fisheries Society, Arizona-New Mexico Chapter of the Wildlife Society, Thatcher, Arizona, February 1-3, 1990: American Fisheries Society, p. 10.

Radtke, D.B., 1990, Contaminant risks in the lower Colorado River valley, Arizona, California, and Nevada, in Minimizing Risk to the Hydrologic Environment: American Institute of Hydrology, 1990 Spring Meeting, Program with Abstracts, Las Vegas, Nevada, March 12-16, 1990, p. 23.

Radtke, D.B., and Kepner, W.G., 1990, Environmental contaminants in the lower Colorado River valley, Arizona, California, and Nevada, in Water quality and quantity issues into the 1990s...Adaptation to current realities: Arizona Hydrological Society's 2nd Annual Symposium, Casa Grande, Arizona, September 14-16, 1989, Part R , Proceedings, p. 1-21.

Radtke, D.B., Kepner, W.G., and Effertz, R.J., 1988, Reconnaissance investigation of water quality, bottom sediment, and biota associated with irrigation drainage in the lower Colorado River valley, Arizona, California, and Nevada, 1986-87: U.S. Geological Survey Water-Resources Investigations Report 88-4002, 77 p. 


\section{Geochemistry of Ground Water in Southwest Alluvial Basins (AZ098)}

Location: Alluvial basins of Arizona and adjacent parts of Nevada, New Mexico, and California

Project Chief: Frederick N. Robertson

Period of Project: October 1986 to September 1992

Cooperating Agency: Regional AquiferSystem Analysis Program (U.S. Geological Survey Federal Program)

Problem: Water quality and its evaluation are of major importance in estimating future usable water resources in alluvial basins because most

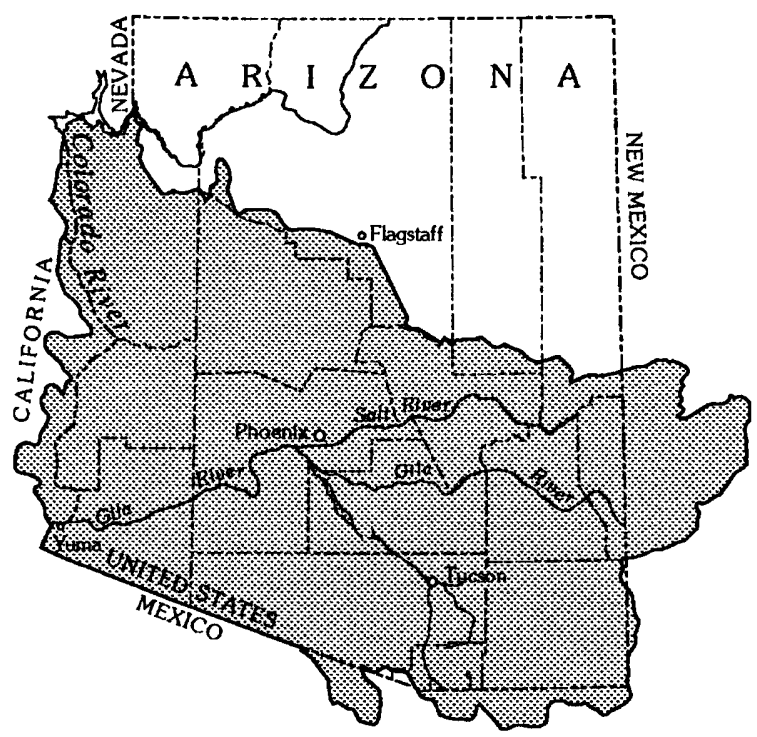
available ground water in the Southwest is stored in these basins. An understanding of geochemistry is essential for this evaluation and prediction of anthropogenic effects on the water quality. Geochemistry also is used to determine critical aquifer characteristics and thus provides an independent analysis of the hydrologic flow system.

Objectives: Implement a comprehensive field-sampling and laboratory program that includes (1) a continuation of geochemical research for development and verification of geochemical concepts and models, (2) development of a silicate carbon-14 model that is compatible with the chemical models, and (3) evaluation of regional and local deuterium and oxygen-18 distribution and its relation to the hydrologic-flow system.

Approach: (1) Implement programs for definition of chemical, mineralogic, and isotopic characteristics of the aquifer. (2) Collect isotopic data for determination of local and regional deuterium and oxygen-18 distributions. (3) Determine ground-water ages, ground-water velocities, and aquifer characteristics from dissolved and solid carbonate species through development of the carbon-14 model.

Progress and Significant Results, Fiscal Years 1986-91: The carbon-14 sampling program was implemented in Safford, San Simon, Willcox, Douglas, and upper and lower San Pedro basins; Vekol Valley; Ranegras Plain; McMullen Valley; and the Quitobaquito area. A data-collection network was installed and maintained for 240 springs in 20 mountain ranges for winter and summer samples of deuterium and oxygen-18. A laboratory program was created for determination of isotopic content for liquid, solid, and gaseous carbon species. A test hole was drilled in Vekol Valley for carbon-14 dating. Existing seasonal isotope sampling of springs was expanded to the northwestern part of the State, giving full State representation. More than 30 
caliche samples were collected from five mountain ranges for carbon-13 and carbon-14 analyses. More than 35 sites near mountain fronts were sampled in 1991 for carbon-13 contents of soil gas.

Plans for Next Year: Limestones in the major mountain ranges in the eastern part of the State will be sampled for carbon-13 and carbon-14 contents. Report writing will include an international presentation, abstracts, journal articles, and a professional paper.

\section{Reports:}

Robertson, F.N., 1986, Occurrence and solubility controls of trace elements in ground water in alluvial basins of Arizona, in Anderson, T.W., and Johnson, A.I., eds., Regional Aquifer Systems of the United States, Southwest Alluvial Basins of Arizona: American Water Resources Association Monograph Series 7, p. 69-80.

1986, Origin and chemistry of ground water along the Colorado River in Arizona, Nevada, and California [abs.], in 30th Annual Meeting of the Arizona-Nevada Academy of Science, Glendale, Arizona, April 19, 1986: Arizona-Nevada Academy of Science, v. 21, p. 56.

1989, Arsenic in ground water under oxidizing conditions, southwest United States [abs.]: Seventh European Meeting, Royal Holloway and Bedford New College, University of London, April 11-14, 1989, p. 15.

1989, Arsenic in ground water under oxidizing conditions, southwest United States, in Journal of Environmental Geochemistry and Health, v. 11, no. 3/4, December 1989: Great Britain, Gem Publishing Company for Science and Technology Letters, p. 171-185.

1989, Ground-water geochemistry and information transfer in alluvial basins in Arizona [extended abs.]: 28th International Geological Congress, Washington, D.C., July 9-19, 1989, Abstracts, v. 2, p. 709-710.

1989, Prediction of water quality through geochemical modeling in undeveloped areas in the desert southwest [abs.], in Pederson, G.L., and Smith, M.M., compilers, U.S. Geological Survey Second National Symposium on Water Quality-Abstracts of the Technical Sessions, Orlando, Florida, November 12-17, 1989: U.S. Geological Survey Open-File Report 89-409, p. 77-78.

1990, Carbon-14 age dating in southeastern Arizona-Isotope and chemical models for interpretation of hydrologic flow system [abs.]: Fourteenth International Radiocarbon Conference, Tucson, Arizona, May 20-24, 1991, p. 236.

1990, Ground-water geochemistry and information transfer in alluvial basins in Arizona, in Simpson, E.S., and Sharp, J.M., eds., Selected Papers on Hydrogeology: International Association of Hydrogeologists, Proceedings of the 28th International Geological Congress, July 9-19, 1989, v. 1, p. 223-236.

1990, Trace constituents in ground water in alluvial basins in Arizona-Source, controls, and prediction [abs.]: London, England, Society for Environmental Geochemistry and Health Programme of the Eighth Annual European Meeting, April 1-4, 1990, p. 15.

1991, Geochemistry of ground water in alluvial basins of Arizona and adjacent parts of Nevada, New Mexico, and California: U.S. Geological Survey Professional Paper 1406-C, 90 p.

1991, Radiocarbon dating in the San Pedro Valley, southeastern Arizona [abs.]: Radiocarbon, v. 33, no. 2 , p. 236-237.

Robertson, F.N., and Garrett, W.B., 1988, Distribution of fluoride in ground water in the alluvial basins of Arizona and adjacent parts of California, Nevada, and New Mexico: U.S. Geological Survey Hydrologic Investigations Atlas HA-665, 3 sheets. 


\section{Basin Characteristics and Streamflow Statistics in Arizona as of 1989 (AZ099)}

Location: Statewide

Project Chief: Joanne M. Garrett

Period of Project: October 1986 to September 1990

Cooperating Agencies: Arizona Department of Water Resources and Flood Control District of Maricopa County

Problem: Basin characteristics and streamflow statistics for Arizona needed to be updated to include all available data and reflect current conditions

Objective: Update the drainage-basin characteristics file

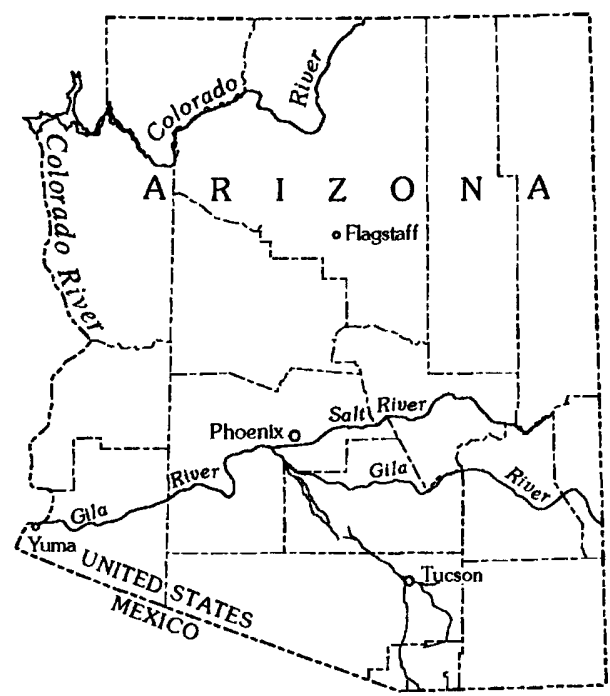
and streamflow statistics for streamflow-gaging stations in the State to include data through water year 1989.

Approach: Update data file of basin characteristics using most recent maps showing physical and climatic characteristics and analyze flood-magnitude and flood-frequency relations for all sites with sufficient data and statistics of daily values at streamflow-gaging stations.

Progress and Significant Results, Fiscal Years 1986-91: Basin characteristics and streamflow statistics were tabulated for 138 continuous-record gaging stations and 176 partial-record gaging stations in Arizona. About 40 percent of the basin characteristics for the State were updated, and streamflow statistics were computed for all continuous-record stations. Flood frequency for continuous- and partial-record stations were computed. Data for continuous-record gaging stations include (1) annual peak discharges; (2) selected basin and climatic characteristics; (3) statistical summaries of mean and annual discharges, magnitude and probability of annual low and high flows, flow duration, and magnitude and probability of annual peak flows. Mean annual discharge and mean monthly discharge for each continuous-record gaging station were compiled. Data for partial-record gaging stations include (1) annual peak discharges, (2) basin and climatic characteristics, and (3) magnitude and probability of annual peak flows. Annual peak discharges were compiled for each streamflow-gaging station in the report.

Plans for Next Year: None. Project complete.

\section{Report:}

Garrett, J.M, and Gellenbeck, D.J., 1991, Basin characteristics and streamflow statistics in Arizona as of 1989: U.S. Geological Survey Water-Resources Investigations Report 91-4041, 612 p. 


\section{Flood Hazards of Distributary-Flow Areas in Southwestern Arizona (AZ100)}

Location: Southwestern Arizona

Project Chief: H. W. Hjalmarson

Period of Project: May 1988 to September 1990

Cooperating Agencies: Arizona Department of Water Resources and Flood Control District of Maricopa County

Problem: Many distributary-flow areas in Arizona behave differently from the alluvial-fan areas described in existing Federal Emergency Management Agency (FEMA) guidelines. The detailed methodology given by FEMA guidelines is for active alluvial fans with the apexes at the mountain front, which are uncommon in Arizona. In

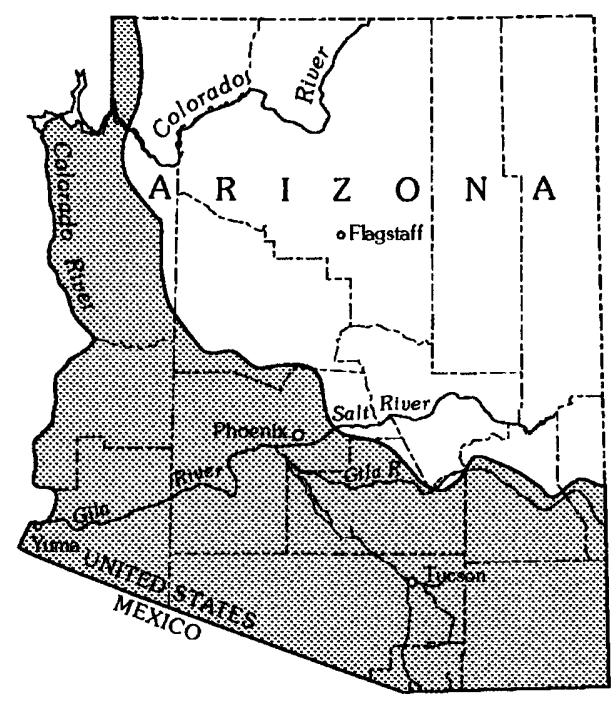
Arizona, many apexes are downslope from the mountain front, commonly in the lower half of the piedmont plain. When following the FEMA guidelines, selection of the location of the apex is difficult. Also, the assumption that flow paths occur at random locations on distributary-flow areas appears to be invalid for many distributary-flow areas in southwestern Arizona.

Objectives: Characterize the nature of flood hazards of distributary-flow areas in southwestern Arizona and classify the types of distributary flow and the associated degree of flood hazard related to the random nature of floodflow.

Approach: The characteristics of the drainage basins and distributary-flow areas, including topography, geology, soils, and vegetation, were defined for 39 sites. Physical characteristics were measured using 7-1/2-minute topographic maps and other qualitative characteristics, such as soil color and relative density of vegetation, which were obtained from aerial and ground reconnaissance and from photographs. The hydraulic and geomorphic features were from unpublished and published information. The type and degree of flood hazard was estimated mainly on the basis of observed geomorphic characteristics and experienced judgment. The estimated degree of flood hazard, which was based mostly on the potential random nature of flow paths, was related to several geomorphic parameters using regression methods. The areas studied were selected in southern Arizona using 7-1/2-minute topographic maps, aerial photographs, and a map of Arizona showing geomorphic features. An areal reconnaissance also was used to confirm selected areas and to select a few additional areas. The initial goal to obtain a sample of distributary-flow areas across southern and western Arizona was accomplished and the 39 sites selected are considered representative of the various types of distributary-flow areas in southern Arizona. 
Progress and Significant Results, Fiscal Years 1988-90: The study was recently completed and the sample of 39 sites ranged from the simplest type of distributary flow with a single diffluence and two channels separated by a high ridge to the most erratic type where active alluvial fans appear to spread floodflow in a random fashion. Areas drained above the primary diffluences (apexes of some alluvial fans) ranged from 0.48 to 95.9 square miles and the distributary-flow areas ranged from about 0.32 to 38.8 square miles. Primary diffluences can be located using 7-1/2-minute topographic maps, aerial photographs and reconnaissance, soils and geologic maps, and field reconnaissance. A consistent procedure for locating the primary diffluence is based on established physiographic and hydrologic principles. Significant parameters to define distributaryflow areas include (1) relative differences in vegetation across distributary-flow areas; (2) relative differences in soil color across distributary-flow areas; and (3) drainage texture of some types of distributary-flow areas, pediments, and inactive alluvial fans. The flood-hazard degree for five types of distributary flow is based on the potentially erratic nature of floodflow. A relative higher numerical rank is assigned to the more erratic areas, and the relation between the rank and several measured geomorphic and hydrologic parameters was investigated. The types of flood hazard appear to be related to a few physiographic parameters such as the amplitude of contour crenulations.

Plans for Next Year: Project complete.

\section{Reports:}

Hjalmarson, H.W., 1988, Flood-hazard zonation in arid lands, in Arid Lands-Hydrology, scour, and water quality: Washington, D.C., National Research Council, Transportation Research Council, Record 1201, p. 1-8.

Hjalmarson, H.W., and Kemna, S.P., 1990, Flood hazards of distributary-flow areas in southern Arizona, in Minimizing Risk to the Hydrologic Environment: American Institute of Hydrology, 1990 Spring Meeting, Program with Abstracts, Las Vegas, Nevada, March 12-16, 1990, p. 20. 


\section{Contaminants in Runoff, Greater Tucson Area (AZ101)}

Location: Southeastern Arizona

Project Chief: Rodney H. Roeske, 1986-90;

Christopher F. Smith, 1990-present

Period of Project: October 1986 to September 1990

Cooperating Agencies: Arizona Department of Water Resources, Pima County Board of Supervisors, and the City of Tucson

Problem: The Arizona Department of Water Resources (ADWR), Pima County Flood Control District, and the City of Tucson are developing plans for the implementation of a demonstration recharge project at the

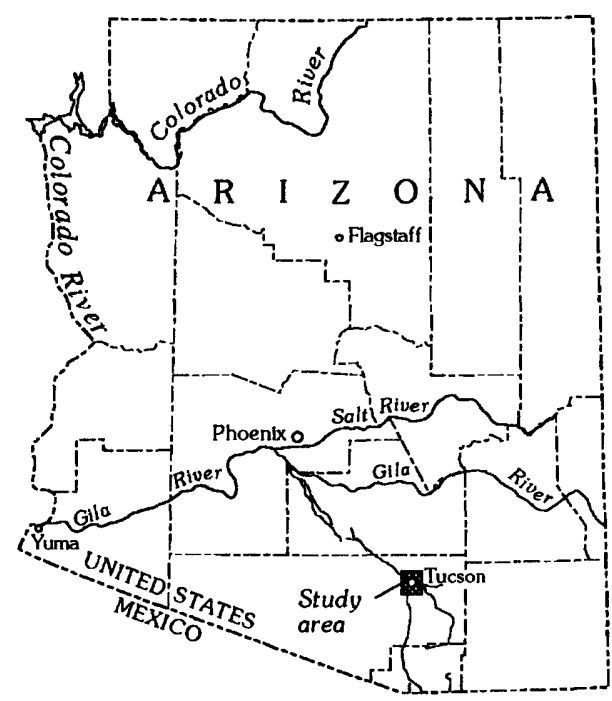
confluence of Alamo Wash and the Rillito River in the Tucson metropolitan area to utilize runoff as a source of water for a recharge facility. In urban areas, concerns exist about the quality of urban surface runoff and the potential for contamination of ground water.

Objectives: Collect necessary data to develop a project whose goals are to (1) determine the occurrence, magnitude, frequency, and transport of storm-water runoff loads of water-quality constituents into and out of a metropolitan area recharge project and (2) determine the fate of contaminants in runoff by monitoring solute transport through the unsaturated zone and the water quality of the alluvial aquifer.

Approach: (1) Runoff quantity and quality will be determined at three inflow sites and one outflow site for the recharge area. (2) Bed material will be sampled at the four sites and in the recharge area. (3) Ground water will be sampled at existing monitor wells. (4) Samples will be analyzed for selected nutrients, common ions, trace metals, and agricultural and industrial organic solutes. (5) Sampling during initial phase of 1 year should cover two summer and two winter runoff events.

Progress and Significant Results, Fiscal Years 1986-91: Surface-water and bed-material samples were collected at four streamflow-gaging stations. Surface-water samples were collected manually and by automatic samplers. Ground-water samples were collected from 11 wells in the study area by ADWR.

Plans for Next Year: ADWR will collect water samples from wells that were previously sampled in the area. Continue sampling storm runoff with focus on previously detected contaminants. Publish basic-data report. 


\section{Predictive Accuracy of Ground-Water Models (AZ103)}

Location: Avra Valley, Arizona.

Project Chief: Randall T. Hanson

Period of Project: January 1987 to September 1991

Cooperating Agencies: Arizona Department of Water Resources and the City of Tucson

Problem: Models were used extensively over the past two decades to gain a better understanding of complex groundwater flow systems. Yet, for all their complexities the models are still nothing more than a simulation based on a number of simplifying assumptions that provide, at best, an approximation of the physical system they attempt to

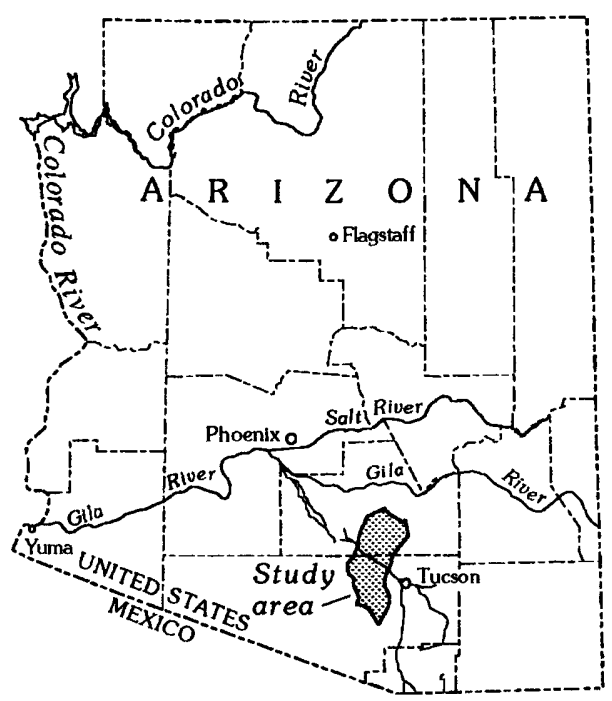
describe. It is the application of simulation models for prediction that has recently raised concern. The reliability of any model-derived prediction of water-level change depends on the reliability of estimates made of the factors affecting the changes. These include changes in stress, land use, population, water-use practices, and aquifer hydraulics.

Objectives: Develop and apply error-analysis techniques that can be used to identify and quantify the relative accuracy of model-predicted historical water-level changes.

Approach: Tests will be carried out using the several existing flow-simulation models of Avra Valley. Methods of error analysis will be applied to the estimation of residual spatial errors. Postaudits for existing models will be done using geostatistical methods of error analysis for selected alternate conceptual models.

Progress and Significant Results, Fiscal Years 1987-91: The geostatistical estimates of developed (1985) heads used about twice as many data as the predevelopment (1940) heads yet the 1985 estimate contains about twice the uncertainty of the 1940 estimates. Postaudit comparison of analog-model prediction was completed, and the 18-year historical (1960-78) comparison was made between USGS and ADWR flow models to determine differences that lead to historical simulation errors. Errors in estimated future pumpage were the largest source of prediction error for the analog-model predictions, and errors in pumpage and transmissivity were the largest source of prediction errors for digital-model predictions. Potential errors in the interpretation of aquifer tests provided substantial bias in various transmissivity distributions used to make historical predictions. Cokriging of transmissivities with specific capacity and silt and clay content provided estimates that were closest to head-conditioned estimates of transmissivity. Alternate conceptual model of steady-state simulation was completed. Application of alternate boundary conditions and 
transmissivity estimates in a postaudit error analysis was guided by standardized calibration error maps that compared kriged heads with predevelopment and developed simulated heads. Modified transmissivity distributions and alternate recharge configurations made relatively small improvements of the overall model error but made significant improvements in selected subregions.

Plans for Next Year: Report entitled "Regional head and transmissivity estimates and postaudit for ground-water flow models of Avra Valley, Arizona," is being prepared for colleague review.

\section{Reports:}

Hanson, R.T., 1989, Postaudit analyses of ground-water models of an alluvial-aquifer system, Avra Valley, Arizona [abs.]: 28th International Geological Congress, Washington, D.C., July 9-19, 1989, Abstracts, v. 2, p. 27. 


\section{Occurrence and Movement of Radionuclides and Other Trace Elements in the Puerco and Lower Little Colorado River Basins, Arizona and New Mexico (AZ104 and AZ110)}

Location: Little Colorado River basin, Arizona and New Mexico

Project Chief: Robert H. Webb, 1986-87;

John R. Gray, 1987-March 1991;

Peter Van Metre, March-September 1991;

Laurie Wirt, September 1991-present

Period of Project: October 1986 to September 1992

Cooperating Agencies: Office of Navajo and Hopi Indian Relocation, Bureau of Indian Affairs, the Navajo Nation, Arizona Department of Water Resources, Arizona Department of Environmental

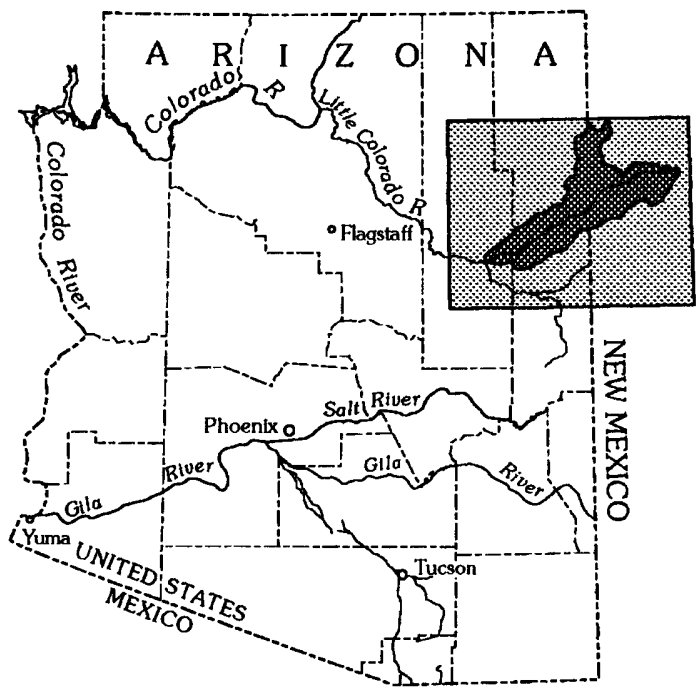
Quality, and New Mexico Environmental Department

Problem: Uranium-mining operations have resulted in releases of radionuclides and other potentially hazardous trace elements to surface water and nearby ground water of the Puerco and Little Colorado Rivers. Releases of mine wastes in addition to the presence of naturally occurring and potentially hazardous trace elements have made some water resources unsafe for use. Neither the extent nor temporal variability of activities of radionuclides or concentrations of other trace elements are known.

Objectives: (1) Determine variability of radionuclides and other trace elements in surface water, ground water, and sediments in and near the Puerco and Little Colorado Rivers. (2) Estimate the amount and extent of contaminant movement between surface water and alluvial ground water. (3) Evaluate occurrence and movement of selected radionuclides and other trace elements between alluvium and adjacent aquifer units. (4) Provide a health-risk assessment associated with use of regional water resources.

Approach: Discharges of water, sediment, and selected radionuclides and other trace elements were monitored at nine streamflow-gaging stations. Ground-water flow characteristics and quality were monitored at more than 50 sites, and quality of sediments was evaluated at seven channel cross sections.

Progress and Significant Results, Fiscal Years 1986-91: Surface water was measured and 50 samples were collected at nine gaged sites and one tributary. Fourteen drivepoints and 39 wells were sampled. Dissolved activities inversely correlated to distance and depth from streams and to 
distance downstream from the mines. Analysis of mine discharges indicates that 300 times more uranium and 6 times more gross-alpha radiation were released by mine dewatering than by a tailings-pond spill in 1979. Isotope analyses, ground-water gradients, and numerical modeling of recharge detected mining effects in the shallow alluvial aquifer. Uranium contamination in the aquifer declined from 1988 to 1991. Effects of mining could not be detected in streamflow.

Plans for Next Year: A nontechnical summary for lay readers is being prepared. Also, three journal articles, a basic-data report, and water-resources investigations reports on ground-water relations and on surface-water relations are being prepared or are in review.

\section{Reports:}

Gray, J.R., Lopes, T.J., and Wirt, Laurie, 1990, Water quality in uranium-mine pits and ground water in the Cameron Uranium Mining Belt, Arizona, in Minimizing Risk to the Hydrologic Environment: American Institute of Hydrology, 1990 Spring Meeting, Program with Abstracts, Las Vegas, Nevada, March 12-16, 1990, p. 19.

Lopes, T.J., 1991, Effects of uranium mining, Puerco River, New Mexico, in Ritter, W.F., ed., Irrigation and Drainage, Proceedings of the 1991 National Conference: New York, American Society of Civil Engineers, p. 508-515.

1990, The impact of uranium in mine dewatering on dissolved gross-alpha and gross-beta activities in the Puerco River, Arizona and New Mexico, in Minimizing Risk to the Hydrologic Environment: American Institute of Hydrology, 1990 Spring Meeting, Program with Abstracts, Las Vegas, Nevada, March 12-16, 1990, p. 25.

Van Metre, P.C., Wirt, Laurie, and Gray, J.R., 1989, Geochemical controls on radionuclide mobility in shallow ground water near an ephemeral stream in northeastern Arizona [abs.], in Pederson, G.L., and Smith, M.M., compilers, U.S. Geological Survey Second National Symposium on Water Quality-Abstracts of the Technical Sessions, Orlando, Florida, November 12-17, 1989: U.S. Geological Survey Open-File Report $89-409$, p. 103.

Webb, R.H., 1987, Preliminary assessment of water quality in the alluvial aquifer of the Puerco River basin, northeastern Arizona: U.S. Geological Survey Water-Resources Investigations Report 87-4126, 70 p.

Webb, R.H., and Rathburn, S.L., 1988, Paleoflood hydrologic research in the southwestern United States, in Arid Lands-Hydrology, scour, and water quality: Washington, D.C., National Research Council, Transportation Research Board, Record 1201, p. 9-21.

Webb, R.H., Rink, G.R., and Favor, B.O., 1987, Distribution of radionuclide and trace elements in ground water, grasses, and surficial sediments associated with the alluvial aquifer along the Puerco River, northeastern Arizona-A reconnaissance sampling program: U.S. Geological Survey Open-File Report 87-206, 108 p.

Webb, R.H., Rink, G.R., and Radtke, D.B., 1987, Preliminary assessment of water quality in the alluvial aquifer of the Puerco River basin, northeastern Arizona: U.S. Geological Survey Water-Resources Investigations Report 87-4126, 70 p.

Wirt, Laurie, Gray, J.R., and Van Metre, P.C., 1989, Occurrence and movement of radionuclides in the Puerco River basin, Arizona and New Mexico [abs.], in Pederson, G.L., and Smith, M.M., compilers, U.S. Geological Survey Second National Symposium on Water Quality-Abstracts of the Technical Sessions, Orlando, Florida, November 12-17, 1989: U.S. Geological Survey Open-File Report 89-409, p. 109.

Wirt, Laurie, Van Metre, P.C., and Favor, Barbara, 1991, Historical water-quality data, Puerco River basin, Arizona and New Mexico: U.S. Geological Survey Open-File Report 91-196, 339 p. 


\section{Trend Analysis of Selected Water-Quality Data at Stream Gages in the Verde River Basin (AZ105)}

Location: Central Arizona

Project Chief: Stanley Baldys, III

Period of Project: October 1986 to August 1990

Cooperating Agency: Arizona Department of Environmental Quality

Problem: Good-quality streamflow in the Verde River basin in central Arizona is a significant resource for recreation and water supply. Degradation of water quality in the Verde River basin may be occurring from large-scale development in the basin. Leachate from

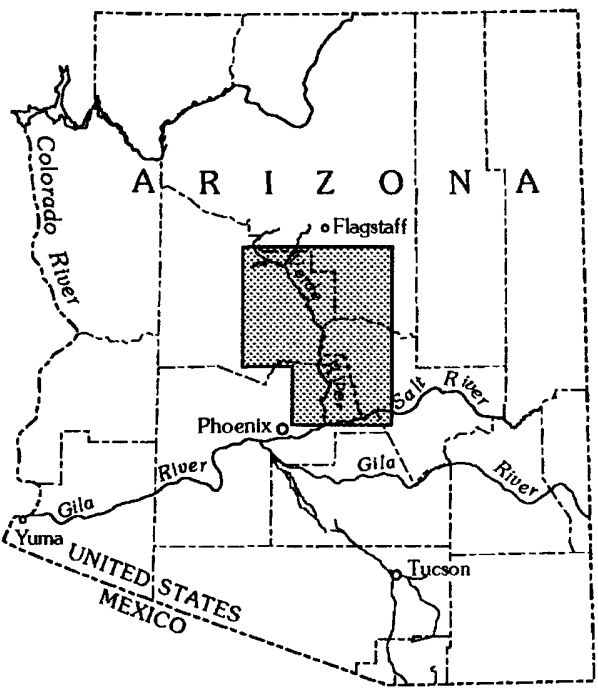
inactive mines in the Jerome area also may be causing a degradation of water quality.

Objective: Identify trends that may exist in the water-quality time series at six streamflow-gaging stations in the Verde River basin in central Arizona.

Approach: Using water-quality data collected at six streamflow-gaging stations in the Verde River basin, apply new trend-analysis techniques recently developed to analyze water-quality trends at each of the six sites. The trend-analysis techniques are (1) regression analysis of residuals with time and (2) seasonal Kendall tau test on flow-adjusted data.

Progress and Significant Results, Fiscal Years 1986-90: Significant increasing trends in dissolved-solids concentrations were found in data collected at the Verde River near Camp Verde site. Large concentrations of dissolved sulfate were present in samples collected at this site. Statistically significant decreasing trends for these constituents were indicated by data collected at the next downstream site, Verde River above Horseshoe Reservoir. Observed trends in six other constituents do not indicate the emergence of water-quality problems in the Verde River basin.

Plans for Next Year: None. Project complete.

\section{Report:}

Baldys, Stanley, III, 1990, Trend analysis of selected water-quality constituents in the Verde River basin, central Arizona: U.S. Geological Survey Water-Resources Investigations Report 90-4128, 55 p. 


\section{Flood Frequency and Erosion Potential in Ephemeral Stream Channels-A Case Study of the Santa Cruz River (AZ107)}

Location: Santa Cruz River, Pima County, Arizona

Project Chief: Robert H. Webb

Period of Project: January 1988 to September 1990

\section{Cooperating Agency: Pima County Board of Supervisors}

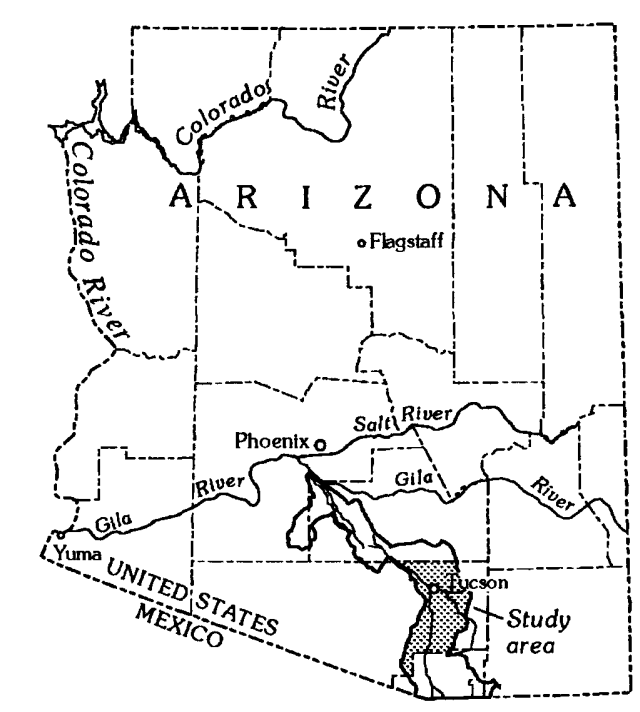

Problem: Flood plains are customarily delineated for the purpose of assessing flood hazards on the assumptions that the stream channel is stable and the flood series is stationary. The assumption of stationarity may be invalid because of climatic fluctuations, channel instability, and urbanization or other changes in land use.

Objectives: (1) Determine if flood distributions in the Santa Cruz River are nonstationary and if they consist of more than one population of floods caused by different storms, climatic fluctuations, or increases in flood discharges caused by headcutting. (2) Apply, modify, and test existing methods for estimating the locational probabilities of channel position and estimate the probability of bank erosion and headcut propagation. (3) Provide reports that will emphasize the dynamic nature of ephemeral stream channels, especially the Santa Cruz River.

Approach: (1) Assess effects of changes in channel morphology on flood peaks. (2) Separate flood series for the Santa Cruz River into different populations according to storm type and determine magnitude-frequency relation for each type of storm. (3) Recombine flood series to produce one composite flood-frequency analysis for the Santa Cruz River at Tucson. (4) Compile historical data on morphology of the Santa Cruz River and combine with field observations to produce a record of channel change and to link the causes of channel change to physical variables.

Progress and Significant Results, Fiscal Years 1988-91: The project is complete except for Director's approval of the second of two reports. A water-supply paper is in press and a number of technical presentations have been made at professional meetings including the American Geophysical Union, American Society of Civil Engineers, and the Geological Society of America.

Plans for Next Year: The report "Channel change on the Santa Cruz River, Pima County, Arizona, 1936-86," by John T. Parker will be submitted for approval as a U.S. Geological Survey water-supply paper. 


\section{Reports:}

Nelson, D.J., Webb, R.H., and Long, Austin, 1990, Analysis of stick-nest rat (Leporillus: Muridae) middens from central Australia, in Bentancourt, J.L., Van Devender, T.R., and Martin, P., eds., Fossil packrat middensThe last 40,000 years of biotic change: Tucson, Arizona, University of Arizona Press, p. 428-434.

Parker, J.T.C., 1989, Historic channel migration of Santa Cruz River, near Tucson, Arizona, in Abstracts with Programs, 1989: Geological Society of America, Rocky Mountain Section, 42nd Annual Meeting, and Cordilleran Section, 85th Annual Meeting, Spokane, Washington, May 8-11, 1989, v. 21, no. 5, Abstract no. 14229 , p. 127.

1990, Channel-changing processes on the Santa Cruz River, Pima County, Arizona, 1936-86, in French, R.H., ed., Hydraulics/Hydrology of Arid Lands: New York, American Society of Civil Engineers, International Symposium, San Diego, California, July 30-August 2, 1990, Proceedings, p. 441-446.

1991, Temporal variability of lateral channel change on the Santa Cruz River, Pima County, Arizona [abs.]: Eos Transactions, American Geophysical Union, v. 71, no. 43, p. 1322.

Webb, R.H., and Baker, V.R., 1986, Floods and channel change in southern Utah [abs.], in Geological Society of America, Abstracts with Programs, Annual Meeting, Flagstaff, Arizona, April 30-May 2, 1986, v. 18, no. 5 , p. 421.

Webb, R.H., and Betancourt, J.L., in press, Climatic variability and flood frequency of the Santa Cruz River, Pima County, Arizona: U.S. Geological Survey Water-Supply Paper 2379, 40 p. 


\section{Prediction Procedures for Ungaged Arid Watersheds in the Southwestern United States (AZ108)}

Location: Southwestern United States including all or part of Arizona, California, Colorado, Idaho, Oregon, Nevada, Utah, Wyoming, New Mexico, and Texas

Project Staff: H.W. Hjalmarson, Chief; B.E. Thomas; and S.D. Waltemeyer

Period of Project: October 1988 to September 1991

Cooperating Agency: Colorado Department of Highways

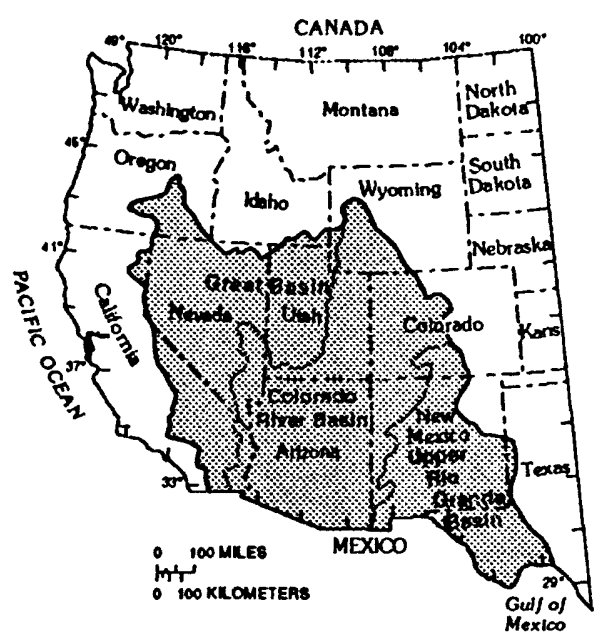

Problem: New and expedient flood-prediction procedures are needed to provide more reliable estimates of flood peaks at gaged and ungaged watersheds in the arid southwestern United States. Regional flood-frequency relations have large errors and large differences at State lines.

Objective: Develop new and expedient regional flood-frequency relations that provide more reliable estimates on ungaged streams in the arid southwestern United States. The focus is on streams that drain arid basins of less than 200 square miles and the 2- to 100-year floods.

Approach: Evaluate new procedures and approaches for flood-peak prediction on the basis of potential to improve accuracy. Assemble and evaluate data base of approximately 1,000 streamflow-gaging stations. Identify through appropriate statistical procedures those watershed parameters that are most useful in estimating flood peaks. Complete final data file and evaluate and develop flood-prediction concepts. Estimate flood peaks and recommend the most favorable method.

Progress and Significant Results, Fiscal Years 1988-91: Regional flood-frequency relations for streams draining ungaged arid basins were defined for the southwestern United States. A new regional skew coefficient of zero is suggested for log-Pearson Type III flood-frequency relations. Amounts of 24-hour 100-year precipitation intensity and the mean annual free water-surface evaporation were digitized from maps and entered in a geographic information system. A new method of defining regional flood-frequency relations for streams with many years of zero flow was developed.

Plans for Next Year: Complete reports. 


\section{Reports:}

Hjalmarson, H.W., 1991, Flood hydrology of arid basins in southwestern United States, in Kirby, W.H., and Tan, W.Y., eds., Proceedings of the United States-People's Republic of China Bilateral Symposium on Droughts and Arid-Region Hydrology, Tucson, Arizona, September 16-20, 1991: U.S. Geological Survey Open-File Report 91-244, p. 59-64.

Hjalmarson, H.W., and Thomas, B.E., 1990, Regional flood-frequency relation for streams with many years of no flow, in French, R.H., ed., Hydraulics/Hydrology of Arid Lands: New York, American Society of Civil Engineers, International Symposium, San Diego, California, July 30-August 2, 1990, Proceedings, p. $483-488$. 


\section{Paleoflood Data-Precision of Discharge Estimates and Accuracy of Estimated Recurrence Interval (AZ109)}

Location: Paria River, north-central Arizona

Project Chief: Robert H. Webb

Period of Project: April 1988 to September 1989

Cooperating Agencies: Bureau of Reclamation and U.S. Geological Survey Federal Program

Problem: Current methods for assessing flood frequency on ungaged rivers and streams are not very precise. Standard errors of estimate can range from 66 to 91 percent. Part of the problem lies in extrapolation of 100 -year discharges from probability distribution fit to short gaging records. Paleoflood methods may improve

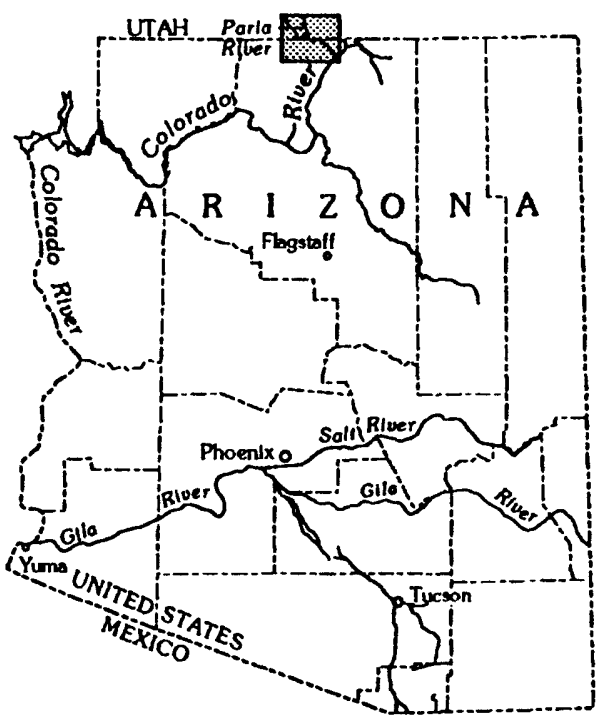
estimates of 100-year discharges, but uncertainties in techniques need to be determined.

Objective: Develop a paleohydrologic record for example rivers in Arizona in order to test the precision of methods commonly used to estimate paleoflood discharges. The frequency of large floods were analyzed for the example rivers using maximum-likelihood techniques to determine the effects of paleohydrologic information on the estimates of 100 -year and other floods.

Approach: One river in Arizona will be selected for analysis. The most likely river, pending reconnaissance to determine if suitable paleoflood sites exist, is the Paria River in north-central Arizona. The site must be reasonably close to an existing long-term gaging station with no large tributaries entering the river between the gaging station and the site. Paleoflood data will be collected and analyzed for uncertainty using existing techniques. Statistical flood-frequency analysis will be performed using maximum-likelihood analysis.

Progress and Significant Results, Fiscal Years 1988-91: Flood deposits were identified and measured in the Paria, San Francisco, and Bill Williams Rivers. Radiocarbon dates from the Paria River indicate one flood approximately 10,400 years BP (before present) and a more complete record for the last 4,300 years BP. Results from the Bill Williams River indicate problems with use of driftwood as water-surface elevation. Preliminary results from the San Francisco River indicate that all known floods have left recognizable deposits. The research has shown that (1) deposits can be found associated with known floods; (2) in cases where deposits are protected from weathering, water-surface elevations are slightly higher than deposits; and (3) care is needed in collection of radiocarbon samples and the type of sample that is dated. 
Plans for Next Year: (1) Finish hydraulic analyses for Paria and Bill Williams River. (2) Complete radiocarbon analyses for the Paria River. (3) Complete stratigraphic analyses for Paria and San Francisco Rivers. (4) Write summary report. 


\section{Mapping Vegetation Water Use Calculated from Remotely Sensed Data as a Function of Soil Moisture (AZ111)}

Location: South-central Arizona

Project Chief: Sandra J. Owen-Joyce

Period of Project: June 1988 to September 1990

Cooperating Agency: Arizona Department of Water Resources

Problem: Preliminary results from earlier experiments at the Maricopa Agricultural Center have shown that evapotranspiration calculated using remotely sensed data compared closely with evapotranspiration measured continuously on the ground using a Bowen ratio system.

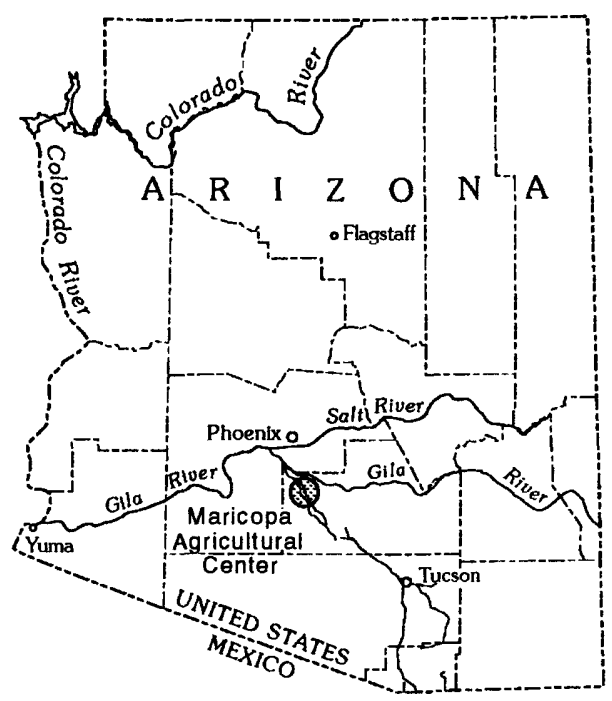
These results also indicated that the spatial distribution of evapotranspiration corresponded more closely to elapsed time since the most recent irrigation than to crop or soil type or vegetation density within a cropped field.

Objective: Map the aerial distribution of evapotranspiration in relation to soil moisture using geographic information system (GIS) software.

Approach: (1) Calculate the spatial distribution of evapotranspiration using an energy-budget approach with remotely sensed, visible, near-infrared, and thermal radiation from the Landsat 5 thematic mapper and SPOT satellites and aircraft. (2) Measure the spatial and temporal distribution of available soil-moisture and soil-water content using gravimetric methods in cotton fields. (3) Create maps of evapotranspiration and maps relating evapotranspiration to soil moisture using GIS techniques.

Progress and Significant Results, Fiscal Years 1988-91: Data collection is complete and data analysis is in progress. The Landsat thematic mapper thermal data are unusable. Aircraft data are available and will be used for the study but spatial coverage is less. One report was published. Agricultural Research Service scientists who developed the remote method of estimating evapotranspiration reported that they have not been able to solve the problem of partial canopy and the method does not work under partial-canopy conditions. The surface-temperature data collected from the aircraft and used for this project do not provide reliable estimates of evapotranspiration. Therefore, the objectives of this project cannot be met when one of two data sets to be compared is unreliable. Cooperator was informed but requires a report. A journal article is being redrafted as a water-resources investigations report to meet the cooperator's request. 
Plans for Next Year: Completion and publication of report, "Soil moisture and remotely sensed spectral data in a partial canopy cotton field at the Maricopa Agricultural Center, Pinal County, Arizona, 1988." The report will be a U.S. Geological Survey water-resources investigations report.

\section{Report:}

Owen-Joyce, S.J., 1988, Field conditions at the Maricopa Agricultural Center, Maricopa County, Arizona, June 13, 1988: U.S. Geological Survey Open-File Report 88-708, 5 p. 


\section{Water Resources Appraisal, San Carlos Indian Reservation (AZ112)}

Location: East-central Arizona

Project Chief: James G. Brown

Period of Project: March 1988 to June 1990

Cooperating Agency: Arizona Department of Water Resources

Problem: The distribution, quality, and quantity of available water resources on the reservations are not well known. An increased understanding of the available water resources on and in the vicinity of the reservation is

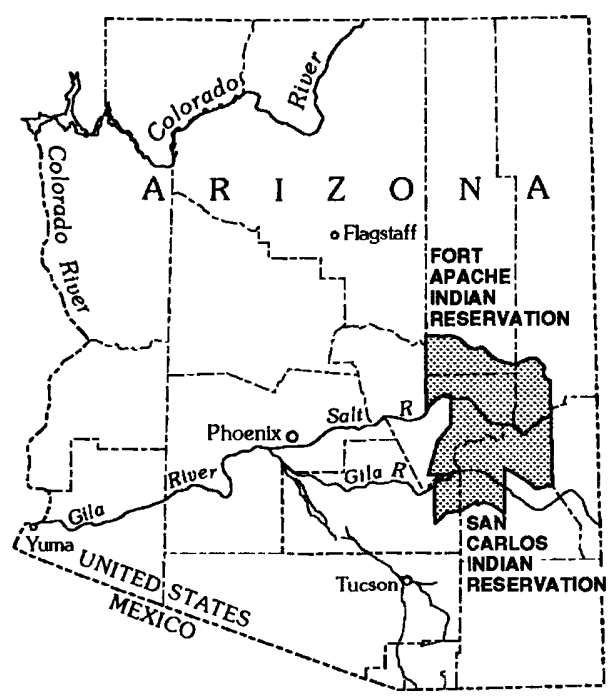
essential to fairly and adequately adjudicate limited water supplies and to better plan for future needs.

Objectives: (1) Quantify and describe the surface-water resources on the Fort Apache and San Carlos Indian Reservations. (2) Evaluate the occurrence of ground-water resources and estimate the quantity in storage on the San Carlos Indian Reservation.

Approach: Surface water: (1) Develop a data file of streamflow-information sites. (2) Evaluate the stationarity of available precipitation and streamflow data. (3) Extend streamflow records of less than 10-years duration using regression and other techniques. (4) Perform statistical analysis of streamflow records. (5) Estimate normal annual mean runoff at sites at and near gaging stations. Ground water: (1) Inventory existing data. (2) Determine extent and physical character of major water-bearing units. (3) Conduct well inventory. (4) Measure water levels in wells. (5) Sample selected wells to determine water-quality characteristics. (6) Measure well yields. (7) Conduct aquifer test(s). (8) Estimate volume of ground water in storage. (9) Organize data and enter into computer storage. (10) Produce maps of aquifer extent and hydrologic characteristics.

Progress and Significant Results, Fiscal Years 1988-91: The ground-water study is complete, and report has been published. The surface-water study is nearly complete; report has received Director's conditional approval.

Plans for Next Year: None. Project complete. 


\section{Reports:}

Baldys, Stanley, III, and Bayles, J.A., 1990, Flow characteristics of streams that drain the Fort Apache and San Carlos Indian Reservations, east-central Arizona, 1930-86: U.S. Geological Survey Water-Resources Investigations Report 90-4053, 59 p.

Brown, J.G., 1989, Geology and ground-water resources of the San Carlos Indian Reservation, Gila, Graham, and Pinal Counties, Arizona: U.S. Geological Survey Water-Resources Investigations Report 89-4152, 39 p. 


\section{Avra Valley Inverse Modeling and Error Analysis Study (AZ113)}

Location: Avra Valley, Arizona

Project Chief: Randall T. Hanson

Period of Project: July 1988 to December 1989

Cooperating Agency: U.S. Department of Energy

Problem: Various models of Avra Valley have used different conceptual models of the ground-water flow system and different estimates of aquifer parameters.

Objectives: Analyze sensitivity of ground-water travel time to variations in aquifer-parameter estimates and the conceptual model of the predevelopment ground-water

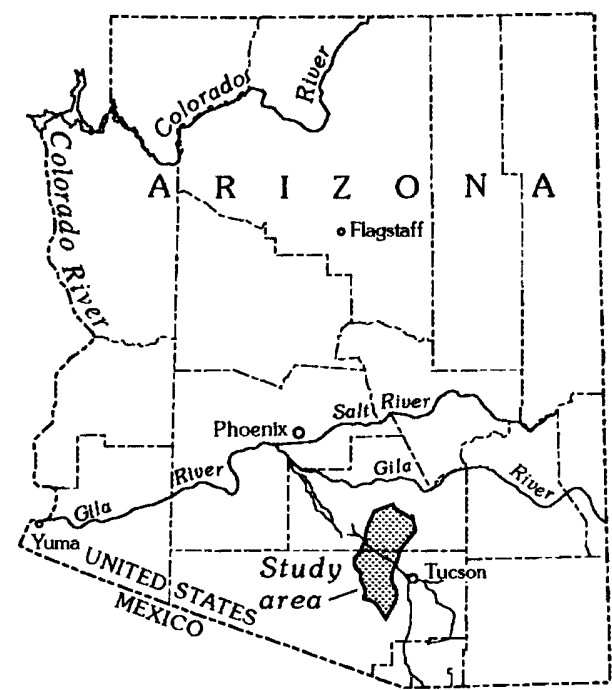
flow system.

Approach: Analysis will use existing model data sets and make a complete set of geostatistical estimates of transmissivity and predevelopment heads with various recharge configurations and zonations to test the sensitivity of ground-water travel-time estimates. Inverse model simulations will use a nonlinear regression model. Alternate conceptual models will be used to assess uncertainty and sensitivity of ground-water travel times for a regional ground-water flow model.

Progress and Significant Results, Fiscal Years 1988-91: A state-of-the-art uncertainty, sensitivity, and error analysis of regional ground-water flow models was developed and presented in the paper from this project. The paper will be used as a guidance document in the evaluation of all simulation models of High-Level Nuclear Waste Repositories by the Nuclear Regulatory Commission. The importance of censoring uncertainty analysis for "realism" was established and had a major effect on predictions of ground-water travel times. Geostatistical estimates are not always the best estimate of aquifer parameters when there is bias in the fundamental data. This results in parameter estimates that are inconsistent with the conceptual model. The effects of alternate conceptual models were found to be a significant aspect of uncertainty analysis. Sensitivity-analysis techniques were found to be dependent on the choice of design point and sensitive to the choice of boundary conditions.

Plans for Next Year: None. Project complete.

\section{Reports:}

Zimmerman, D.A., Hanson, R.T., and Davis, P.A., 1991, A comparison of parameter estimation and sensitivity analysis techniques and their impact on the uncertainty in ground water flow model predictions: U.S. Nuclear Regulatory Commission NUREG/CR-5522 (Sandia National Laboratories SAND90-0128), 197 p. 


\section{National Water Information System (NWIS) Program-PRIME-Based NWIS Ground-Water Site Inventory Subsystem Maintenance (AZ114)}

Location: Administrative

Project Chief: Colleen A. Babcock

Period of Project: Continuous since January 1989

Cooperating Agency: Federal Program

Problem: The development of a new National Water Information System (NWIS) requires the effective and efficient management of large numbers of personnel in many locations. The new NWIS must be designed and implemented, and the existing NWIS Ground Water Site Inventory (GWSI) subsystems on the PRIME minicomputers must be maintained.

Objectives: Provide data-base management for the GWSI subsystem and contribute to the planning and design effort for the new NWIS. As Data Base Manager, the project chief will direct the maintenance of computer software (programs) and provide user assistance and training related to the analysis, storage, and retrieval of ground-water data. The project chief will serve as a resource person and in whatever capacity is necessary to expedite the design, development, and implementation of the new NWIS.

Approach: This project will provide funds for the project chiefs in District, State, and Subdistrict offices to provide the following software design and maintenance activities: (1) Assure computer software compatibility with new revisions of the PRIME minicomputer's operating system PRIMOS, test all software functions under new revisions of PRIMOS, and make necessary modifications to software and report operating-system problems to the distributed information systems (DIS) staff. (2) Identify and repair reported malfunctions in the computer software and prioritize items needing attention based on importance; identify solutions to problems using various software debugging techniques, make modifications to software code, and test revised software. (3) Prepare revisions of the computer software as a part of NWIS releases. (4) Provide user support and training for computer processing techniques in distributed environment using minicomputer. (5) Coordinate activities with other NWIS data managers.

Progress and Significant Results, Fiscal Years 1989-91: Tested and released version 91.1 on schedule. Conducted user training seminars for GWSI and coordinated and conducted NWIS data base administrators' seminar. Identified, prioritized, and planned for software changes to the PRIME GWSI system. Provided technical support in the design and development of NWIS-II. Provided user assistance as needed.

Plans for Next Year: Continue to test and release software changes, provide technical support in the design and development of NWIS-II, and provide user assistance as needed. 


\section{Reports:}

Babcock, Colleen, 1990, Ground-water edit program, in National Water Information System User's Manual, v. 2, Chap. 4, Ground-Water Site Inventory System: U.S. Geological Survey Open-File Report 89-587, p. 6-1 to 6-12.

1990, Ground-water update program, in National Water Information System User's Manual, v. 2, Chap. 4, Grou `d-Water Site Inventory System: U.S. Geological Survey Open-File Report 89-587, p. 7-1 to $7-12$.

1990, Error messages, in National Water Information System User's Manual, v. 2, Chap. 4, GroundWater Site Inventory System: U.S. Geological Survey Open-File Report 89-587, p. 14-1 to 14-16.

Babcock, Colleen, Luckey, R.R., Morgan, C.O., and Stephens, D.M., 1990, Ground-Water Site Inventory Coding Instructions, in National Water Information System User's Manual, v. 2, Chap. 4, Ground-Water Site Inventory System: U.S. Geological Survey Open-File Report 89-587, p. 2-1 to 2-124. 


\section{Spatial and Temporal Variability of Point Micrometeorological Data Used To Estimate Regional Evapotranspiration (AZ115)}

Location: South-central Arizona

Project Chief: Sandra J. Owen-Joyce

Period of Project: April 1989 to September 1992

Cooperating Agency: Bureau of Reclamation

Problem: Techniques have been developed to estimate evapotranspiration by using remotely sensed data and ground-based micrometeorological data. The extent to which the technique will yield reasonable estimates of evapotranspiration is uncertain because of uncertainties in the areal extent over which ground-based data, such as measurements of temperature and vapor pressure, may be

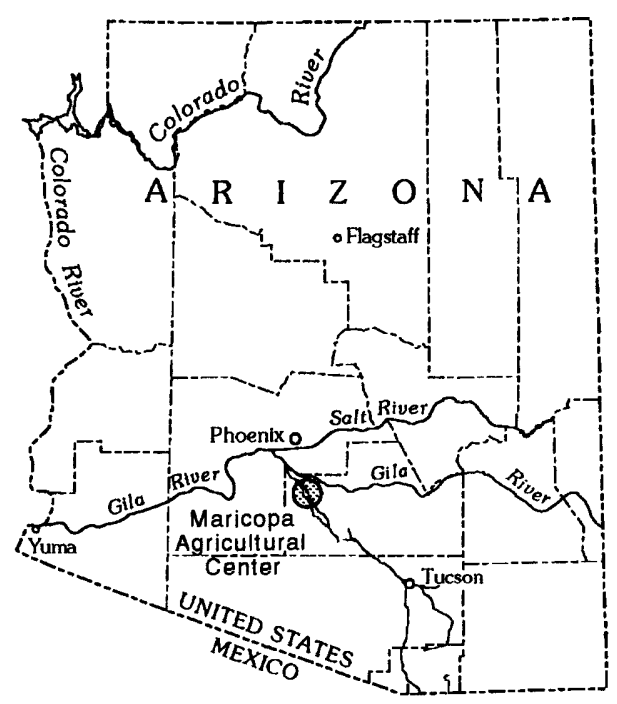
extrapolated. Resolution of these uncertainties will allow for the development of an appropriate micrometeorological-monitoring network which, in turn, will lead to more accurate estimates of regional evapotranspiration.

Objective: Evaluate the spatial and temporal variability of ground-based micrometeorological point data needed to estimate regional-scale evapotranspiration with remotely sensed data.

Approach: Data collection: Weather stations will monitor the ground-based environmental parameters required to develop evapotranspiration estimates from remote-sensing techniques at an existing station and at five temporary stations. Contract with the University of Arizona for meteorological data collection and processing. Data analysis: Assess (1) areal extent over which meteorological variables can be extrapolated, (2) appropriate time interval over which point micrometeorological data should be averaged for use in estimating evapotranspiration from remotely sensed data, and (3) potential errors in these applications.

Progress and Significant Results, Fiscal Years 1989-91: Project planning completed. Project procedures defined. Data collection completed. Data processing in progress. Five reports and one abstract published. Two presentations given at meetings. Initial finding is that the condition of the underlying and surrounding surfaces affects the data collected more than does the distance between stations when data are collected over similar surfaces.

Plans for Next Year: Data compilation and analysis. Preparation of maps. Report writing.

\section{Reports:}

Brown, P.W., and Owen-Joyce, S.J., 1991, Remote sensing and evapotranspiration estimates: Influence of ground-based meteorological data, in Kirby, W.H., and Tan, W.Y., Proceedings of the United States-People's 
Republic of China Bilateral Symposium on Droughts and Arid-Region Hydrology, Tucson, Arizona, September 16-20, 1991: U.S. Geological Survey Open-File Report 91-244, p. 161-166.

Brown, P.W., Owen-Joyce, S.J., Daughtry, C.S.T., and Kustus, W.P., 1990, Effect of underlying surface on ground-based environmental data collected in an arid region [abs.], in Agronomy Abstracts, 1990 Annual Meetings, American Society of Agronomy, Crop Science Society of America, Soil Science Society of America, San Antonio, Texas, October 21-26, 1990, p. 15.

Owen-Joyce, S.J., 1989, Field conditions at the Maricopa Agricultural Center, Pinal County, Arizona, April 9, 1989: U.S. Geological Survey Open-File Report 89-377, 14 p.

1989, Field conditions at the Maricopa Agricultural Center, Pinal County, Arizona, June 16, 1989: U.S. Geological Survey Open-File Report 89-392, 11 p.

1989, Field conditions at the Maricopa Agricultural Center, Pinal County, Arizona, September 28, 1989: U.S. Geological Survey Open-File Report 89-590, 12 p.

1991, Field conditions at the Maricopa Agricultural Center, Pinal County, Arizona, June 26-28, 1990: U.S. Geological Survey Open-File Report 91-461, 15 p. 


\section{Trend Analysis of Water-Quality Data at Stream Gages in the Gila River Basin (AZ116)}

Location: Central Arizona and western New Mexico

Project Chief: Stanley Baldys, III

Period of Project: July 1989 to September 1990

Cooperating Agency: Arizona Department of Environmental Quality

Problem: Water-resources managers are concerned about the possible degradation of water quality in the Gila River basin caused by

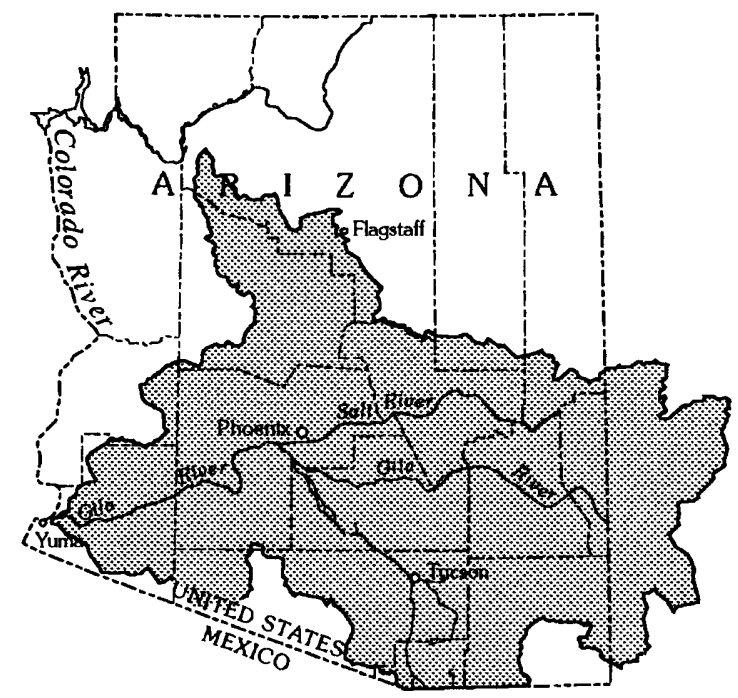
anthropogenic sources. The Gila River basin is the major source of surface-water supplies for the Phoenix metropolitan area. A large water-quality data base has been compiled over the last 20 years from samples collected at various sites in the drainage basins. The data base is of sufficient length for trend analyses to detect temporal changes in water-quality constituents.

Objective: Identify trends that may exist in the water-quality time series at 13 streamflow-gaging stations in the Gila River basin in central Arizona and western New Mexico.

Approach: Historical data were examined, compiled, and analyzed for time trends using the seasonal Kendall tau test on water-quality data adjusted for the effects of an exogenous variable (stream discharge).

Progress and Significant Results, Fiscal Years 1989-91: Data base has been compiled, collated, and analyzed. Trend analysis was performed on data using the seasonal Kendall tau test on flowadjusted data. Results have been tabulated and manuscript has been prepared. The report, which is planned as a water-resources investigations report, is in review.

Plans for Next Year: The water-resources investigations report is expected to be approved and published. 


\section{Grand Canyon Hydrologic Data and Data-Base Management (AZ117)}

Location: Northern Arizona and southern Utah

Project Chief: Robert J. Hart

Period of Project: Continuous since June 1990

Cooperating Agency: Bureau of Reclamation

Problem: At present, no integrated system of data storage and management is available that will provide a repository and source of the data needed by scientists involved in the Glen Canyon Environmental Studies Phase II (GCES II). Scientists involved in these studies rely on hydrologic data for their research.

Objectives: Provide hydrologic data for all scientists and

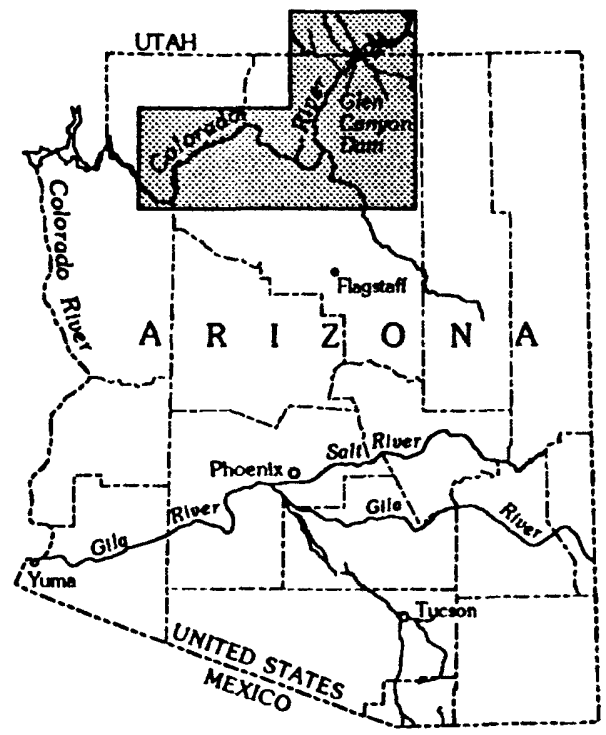
agencies in the evaluation of the hypotheses proposed for an Environmental Impact Statement on the operation of Glen Canyon Dam and provide an easily accessible centralized data base for use by all participants and other water-data users.

Approach: Basic hydrologic data, including streamflow, water quality, and sediment, will be collected for GCES II at eight existing sites and three proposed sites. All stations will be equipped with satellite telemetry, and data will be entered in the data base within hours of its acquisition for in-site measurements (for example, surface-water discharge measurements). USGS will review and enter data provided by USBR on hourly releases from the dam. USGS will collect stage data at approximately 50 sites throughout the Grand Canyon. USGS will establish a centralized data base and provide training to scientists who use the data base. This project is a part of a larger effort that includes projects Lake Powell Water Quality (AZ118), Grand Canyon Water Quality (AZ119), Grand Canyon Beach Evolution (AZ120), and Grand Canyon Sediment Transport (AZ121).

Progress and Significant Results, Fiscal Years 1990-91: Continuous records of river stage and various chemical constituents were collected at 11 gaging stations on the Colorado River and major tributaries. All data were entered into the project data base. Review of data for release and publication are in progress. River stage at approximately 50 temporary locations in the Grand Canyon is being recorded. Data have been entered into the project data base. Data are being used primarily by USGS scientists in the development of streamflow-hydrologic models.

Plans for Next Year: A data report including water-discharge and water-quality measurements of $\mathrm{pH}$, water temperature, dissolved oxygen, and specific conductance will be prepared for wates years 1990-92. 


\section{Lake Powell Water Quality (AZ118)}

Location: Northern Arizona and southern Utah

Project Chief: Robert J. Hart

Period of Project: June 1990 to September 1991

Cooperating Agency: Bureau of Reclamation

Problem: The location of the penstocks of Glen Canyon Dam in the water column of the dam pool controls the quality of water being released to the downstream environment of the Colorado River. Because of their location, the penstocks generally take in cold water from the hypolimnion, which is released downstream. This cold water may not be conducive to native fish and other aquatic life.

Objectives: (1) Determine the general water-quality

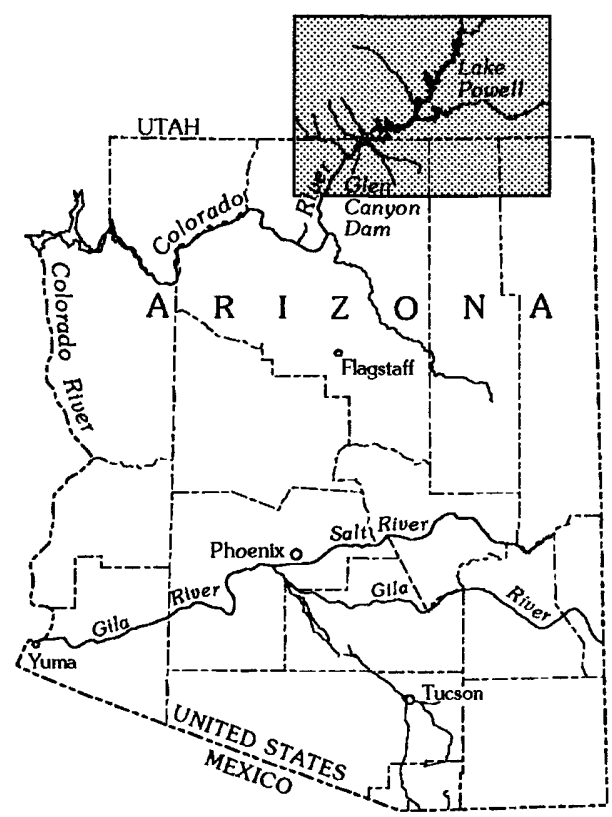
characteristics of the dam pool. (2) Determine temporal and spatial variations in water quality. (3) Determine chemical and thermal stratification and distribution near the penstocks. (4) Determine factors that affect nutrient levels at the penstocks.

Approach: The study will include point sampling through the water column in the dam pool at four or five locations near the dam. Sampling will be done in a 24-hour period at a frequency of every 6 hours. Water-column measurements will include dissolved oxygen, $\mathrm{pH}$, specific conductance, light intensity, and water temperature. As many as six depths in each water column will be sampled. Water samples will be collected directly from dam outlet structures (draft tubes) at the same frequency and time as lake samples. This project is a part of a larger effort that includes projects Grand Canyon Hydrologic Data and Data-Base Management (AZ117), Grand Canyon Water Quality (AZ119), Grand Canyon Beach Evolution (AZ120), and Grand Canyon Sediment Transport (AZ121).

Progress and Significant Results, Fiscal Years 1990-91: Water-quality samples were collected from the dam-pool area of Lake Powell and from the draft tubes of Glen Canyon Dam. Water samples were collected for analysis approximately bimonthly for various reservoir-release patterns and over a diel cycle. Lake-profile measurements of $\mathrm{pH}$, water temperature, dissolved oxygen, and specific conductance were made approximately monthly. Processing and analysis of samples were completed. A report describing the results of the project has been written and is in the review process.

Plans for Next Year: Complete and publish the report. Plans to expand the scope of the work are contingent on funding, which is not yet finalized. 


\section{Grand Canyon Water Quality (AZ119)}

Location: Northern Arizona

Project Chief: Howard E. Taylor

Period of Project: June 1990 to September 1991

Cooperating Agency: Bureau of Reclamation

Problem: Prior to the construction of Glen Canyon Dam, water quality of the Colorado River was in at least a seasonal equilibrium in that organisms had evolved within given seasonal chemical, temperature, sediment, and flow ranges. Since the dam was constructed, the river system has been in disequilibrium with regard to chemical concentrations and constituents, temperature, sediment, and flow. The river below the dam is a "new river," having

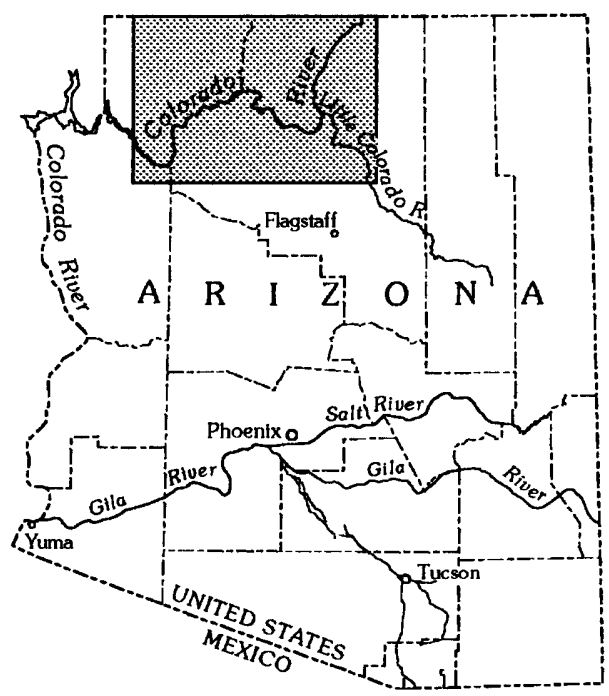
much clearer and cooler water and a different flow pattern.

Objective: To understand the chemical and biological processes and their responses under various flow-release patterns so that conceptual models of the relation of chemical and biological processes to flow, water temperature, and seasonal-climate patterns can be developed.

Approach: Synoptic experiments will be used for collecting samples for chemical and biological constituents. These experiments will be based on regulated and natural flow-release patterns and on seasonality. Teams of scientists will be stationed at selected sites along the river and near the confluences of the tributaries. At a predetermined time, the experiment will begin, and measurements and samples of selected constituents will be made every 6 hours over a 48-hour period. This project is a part of a larger effort that includes projects Grand Canyon Hydrologic Data and Data-Base Management (AZ117), Lake Powell Water Quality (AZ118), Grand Canyon Beach Evolution (AZ120), and Grand Canyon Sediment Transport (AZ121). The description of this project includes the work of Robert J. Hart and other Arizona District personnel.

Progress and Significant Results, Fiscal Years 1990-91: Two synoptic experiments were successfully completed. Water-quality data including chemical and biological constituents were collected over 48-hour time periods during the experiments at 16 sites along the Colorado River, Grand Canyon. More than 70 USGS scientists from across the country participated in this unique data-collection effort. Data collected during these experiments will provide information on the water quality of the Colorado River for two seasons, for different river flows, and over a diel cycle. Chemical and biological data are currently being analyzed and tabulated for publication.

Plans for Next Year: Begin site-specific studies based on results from the two synoptic studies. A report on the results of the two synoptic studies will be completed. 


\section{Grand Canyon Beach Evolution (AZ120)}

Location: Northern Arizona

Project Chief: Julia B. Graf

Period of Project: Continuous since June 1990

Cooperating Agency: Bureau of Reclamation

Problem: Glen Canyon Dam has changed the flow and sediment supply of the Colorado River in the Grand Canyon. To operate the dam to minimize adverse effects, managers must have answers to questions such as how long camping beaches can be maintained under normal powerplant flows and whether beaches can be rebuilt by floods. Predictive models of transport and deposition of

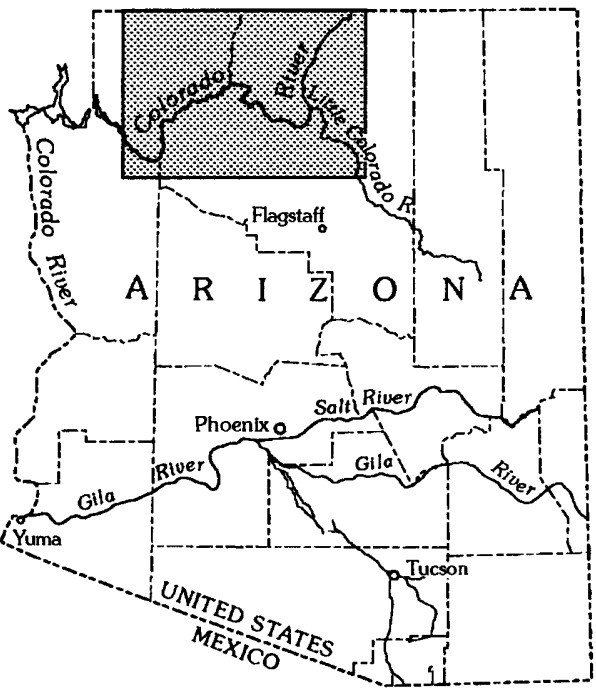
sediment within eddies and across the boundary between the main channel and the eddies are required to answer those questions, because other methods are limited to a narrow range of conditions. Other processes affecting sand bars must be understood if the responses of bars to dam releases are to be predicted.

Objectives: (1) Determine the amount of sand stored in the river corridor. (2) Develop a preliminary descriptive understanding of bar evolution. (3) Evaluate the effect of debris flows on bars. (4) Make a preliminary set of model calculations of bar changes for a range of flow scenarios and bar types typical of the Grand Canyon. (5) Make a preliminary determination of the effect of ground-water movement into and out of the bars on bar stability.

Approach: Sand thickness will be determined by coring and seismic-reflection surveys. The evolution of several bars will be detailed by study of internal structures. An eddy-flow model will be developed to provide velocity and shear-stress distributions required for sediment transport and bed-evolution models. Bathymetric and topographic surveys will provide data required to test the models for Grand Canyon eddies. The effect of debris flows that occur within the period of study on alluvial fans and adjacent sand bars will be measured directly, and photographic analysis will provide information on bar changes in response to earlier debris flows. Head and water temperature in the saturated zone and deformation of sediments during unsteady flow will be measured, and a stress-strain model that simulates slumping, fissuring, and rotational failure as well as spring sapping will be developed. This project is a part of a larger effort that includes projects Grand Canyon Hydrologic Data and Data-Base Management (AZ117), Lake Powell Water Quality (AZ118), Grand Canyon Water Quality (AZ119), and Grand Canyon Sediment Transport (AZ121). The description of this project includes the work of David M. Rubin, Geologic Division, and Edmund D. Andrews, Jonathan M. Nelson, and Robert H. Webb of the Water Resources Division, National Research Program, in addition to Arizona District personnel. 
Progress and Significant Results, Fiscal Years 1990-91: Data were collected during research flows in all phases of the study. Seismic refraction and vibrocoring of sand bars allowed determination of thickness of sand on several bars that were studied in detail. Depositional history of four bars has been worked out, giving considerable insight into bar change. Head and temperature changes were measured by a dense network of sensors on three bars. Tilt of riverward bar faces was measured. Photographic analysis of long-term changes in several bars continued. Monitoring of changes in sand bars caused by recent debris flows, development of eddy-flow and main channel-eddy exchange models, and model testing with laboratory data also continued. Studies of the history of the most common types of sand bars reveal a complex response of sand bars to varying flow patterns in eddies. Evaluation of seismic-reflection profiles of the channel bottom showed that sand in the channel is thinner than had been estimated, and vibrocoring and geophysical methods showed sand deposits in eddies of more than $30 \mathrm{ft}$. Response of ground water in sand bars to unsteady flow is complex and dependent on local geometry and bar materials. Historical analysis of sand-bar change shows that in the last 100 years bars have decreased in the upper reaches of the study area but have increased in the downstream reaches.

Plans for Next Year: Data collection will continue on a smaller scale. Data will continue to be collected on (1) sand thickness and aerial extent, (2) depositional history of sand bars, (3) groundwater response to unsteady flow and its effect on bar stability, (4) historical analysis of bar change, and (5) eddy model development and verification. Reports giving results of studies to the end of 1991 will be prepared, and data evaluation will continue. Plans are contingent on funding, which is not yet finalized. 


\section{Grand Canyon Sediment Transport (AZ121)}

Location: Northern Arizona

Project Chief: Julia B. Graf

Period of Project: Continuous since June 1990

Cooperating Agency: Bureau of Reclamation

Problem: State and Federal agencies charged with management of the Colorado River in Glen and Grand Canyons must be able to assess the effects of alternative flow releases to continue to get maximum benefit from the control of flow with minimum adverse effects to the riparian environment. The salient characteristics of

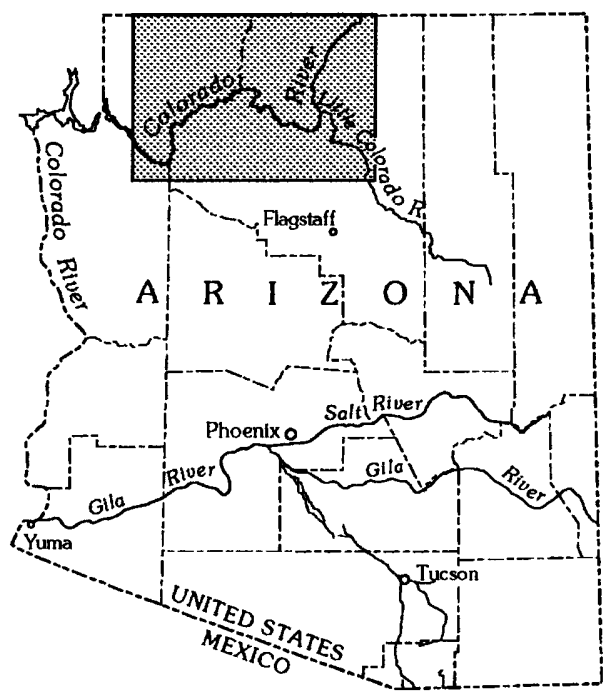
hydraulic controls and flow in the river downstream from the dam must be understood physically and modeled mathematically before the effects of dam-operation environment can be assessed.

Objective: Develop models capable of predicting stage, discharge, conservative-solute transport, and sand transport so that the effects of various dam-operation scenarios on the riparian zone in Grand Canyon can be determined.

Approach: Temporary stage gages will be installed about every 5 miles along the channel to provide data on amplitude and shape of the free surface wave for development of the flow model. The ability of the model to correctly transport the fluid mass will be checked with dye-tracer studies at as many as four flow conditions. Bed-geometry and bed-material characteristics will be measured in selected reaches, and methods for characterizing geometry in other reaches developed. Intensive sediment collection will be done at one site to investigate the feasibility of using a local model to improve sand-rating curves. This project is a part of a larger effort that includes projects Grand Canyon Hydrologic Data and Data-Base Management (AZ117), Lake Powell Water Quality (AZ118), Grand Canyon Water Quality (AZ119), and Grand Canyon Beach Evolution (AZ120). The description of this project includes the work of J. Dungan Smith and Stephen Wiele of the Water Resources Division, National Research Program, in addition to Arizona District personnel.

Progress and Significant Results, Fiscal Years 1990-91: An initial set of data on bed geometry and bed roughness was collected in six reaches that range in length from 1 to 5 miles. Two measurements of travel time and dispersion in a 235-mile reach downstream from Lees Ferry were made at a steady flow of 15,000 cubic feet per second and an unsteady flow with a mean of 15,000 cubic feet per second, and two measurements-at 15,000 and 26,000 cubic feet per second - were made in the reach between Glen Canyon Dam and Lees Ferry. Work on eolian 
inputs to the system was postponed because of lack of funding. Detailed velocity and suspendedsediment fields in a gaged cross section above National Canyon were measured for spring and summer research-flow periods. Flow-model development was begun. Analysis of data collected in fiscal year 1991 has just begun. Travel time and dispersion measurements show that dispersion is atypical - time-concentration curves at a site do not show the "tails" typical of such curves. Depth sounding and video of the channel bottom show that the channel geometry and bed roughness varies dramatically over very short distances. Roughness in a short reach can range from smooth sand bottom to large talus blocks. Pools in most reaches contain some sand. Narrow, high-velocity reaches in the upstream parts of the study have sand dunes moving over a gravel bed. In other pools, sand is thick enough to form large fields of dunes with little gravel. Suspendedsediment measurements at National Canyon show that sand transport is very low except at flows near the powerplant peak discharge. A report describing travel times and longitudinal dispersion of reservoir releases has been written and is in review.

Plans for Next Year: Data collection to support the modeling effort will continue with additional bed-geometry and roughness measurements and dispersion and travel-time measurements at low flow. Rating-curve development techniques developed with the National Canyon data set will be attempted at a second gaging station. If funding permits, movement of sand downstream from the two major tributaries will be monitored under the restricted flows imposed by the Department of the Interior. Analysis of channel-geometry and dispersion data and development of the flow model will continue. Progress reports and an interpretive report will be prepared. Plans are contingent on funding, which is not yet finalized. 


\section{Accounting for Diversions of Colorado River Water Drawn from the Main Stream by Underground Pumping in the Lower Colorado River Basin (AZ122)}

Location: Lower Colorado River valley, Arizona, California, and Nevada

Project Chief: Richard P. Wilson

Period of Project: April 1990 to September 1992

Cooperating Agency: Bureau of Reclamation

Problem: The Secretary of the Interior cannot fully account for diversions of Colorado River water drawn from the mainstream by underground pumping in the lower Colorado River valley because the subsurface limits of the river-aquifer flow system are unknown and a simple method of

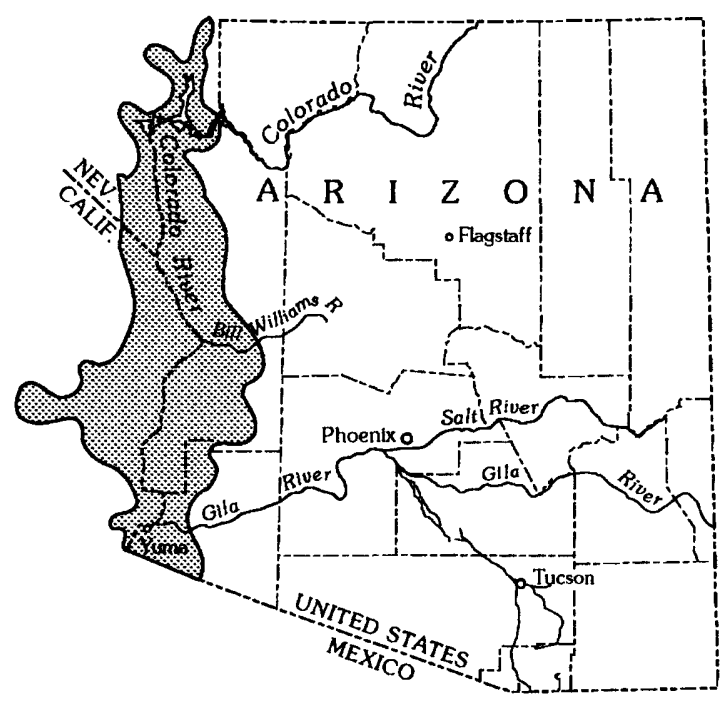
separating wells that yield river water from those that yield tributary water has not been developed. Water pumped from beneath the flood plain is accounted for as river water, but water pumped from beneath the adjacent alluvial terraces and slopes is not presently included in the accounting. A method of identifying the wells that yield river water is needed so that the quantity of river water pumped from the river-aquifer system outside the flood plain can be accounted for.

Objectives: Delineate the extent of the river-aquifer system in the lower Colorado River valley and those adjacent basins that have significant subsurface hydraulic connection to the river-aquifer system of the Colorado River. Define the geometry, altitude, and boundaries of a conceptual potentiometric surface (accounting surface) between the edges of the flood plain and the riveraquifer boundary, below which drawdown caused by underground pumping may be assumed to be diverting water from the Colorado River. Provide a tabulation of inventoried wells within the accounting-surface boundary.

Approach: The extent of the river-aquifer system will be determined from available geologic and geophysical information and measured water levels for many areas and by estimating the thickness and extent of basin-fill alluvium by gravity and magnetic geophysical methods. Stratigraphy, geophysical logs, and water levels from a few test holes and existing wells will be used to calibrate and improve the geophysical studies. The accounting surface will be defined by the geometry of the potentiometric surface near the edge of the flood plain on each side of the valley and extended horizontally outward approximately perpendicular to the mean direction of flow in the riveraquifer system to the aquifer boundary. The accounting surface generally will slope downvalley at about the average river slope. For various reaches, the altitude of the accounting surface will be defined by water-surface profiles of the river and drainage ditches or annual maximum monthly stage of reservoirs and wetlands. 
Progress and Significant Results, Fiscal Years 1990-91: Aerial photographs of the entire study area and nearly all available hydrologic, geologic, and geophysical data were obtained. Well inventory in Mohave Valley is more than 90 percent complete. Well inventory is complete in Chemehuevi Valley and Lake Havasu City except for about four wells on the Chemehuevi Indian Reservation and in Milpitas Wash-Smoketree Valley. Most of the wells in the Parker, Vidal, McCoy Wash, and Palo Verde Mesa areas are inventoried. At this time, more than 900 wells have been inventoried; perhaps about 700 wells remain to be visited above Laguna Dam. A proposal to conduct gravity and magnetic surveys of 10 areas was funded by the Bureau of Reclamation in April 1991. Preliminary surveys and installation of bench marks began in late August using three global positioning system (GPS) receivers made available by the Bureau of Reclamation. Gravity data collection began in late September. River profiles required to prepare regulatory-surface maps will be available from the Bureau of Reclamation early in FY 1992. Target stages for Lake Mead, Lake Mohave, and Lake Havasu have been obtained. Base maps that contain river-mile points have been provided by the Bureau of Reclamation.

Plans for Next Year: Continue well inventory and water-level measurements. Continue GPS surveys of well sites, drainage ditches, and wetlands. Continue geophysical gravity and magnetic surveys of selected ground-water basins. Visit mouth of Virgin River at Lake Mead. Prepare preliminary accounting-surface maps and most of the final accounting-surface maps. Prepare text and preliminary graphics for final report.

\section{Reports:}

Pool, D.R., and Hatch, Michael, 1991, Gravity response to storage change in the vicinity of infiltration basins [abs.]: Phoenix, Salt River Project, Fifth Biennial Symposium on Artificial Recharge of Groundwater, Tucson, Arizona, May 29-31, 1991, Proceedings, p. 171.

Wilson, R.P., 1991, The regulatory surface-A proposed method of identifying wells that yield Colorado River water [abs.]: Bethesda, Maryland, American Water Resources Association, 27th Annual Conference Water Management of River Systems and Symposium Resource Development of the Lower Mississippi River, New Orleans, Louisiana, September 8-13, 1991, p. 359-360. 


\section{Hydrologic Investigation of Montezuma Well and Surrounding Area (AZ123)}

Location: Central Arizona

Project Chief: James R. Marie, 1990-91;

Alice D. Konieczki, 1991-present

Period of Project: September 1990 to September 1992

\section{Cooperating Agency: National Park Service}

Problem: The information required to estimate reliably the effects of current water use in the area of springs that discharge into Montezuma Well is not available. Few data are available to help estimate the effects of future water use or to forecast potential adverse, and possibly irreversible, effects on Montezuma Well. Using the available

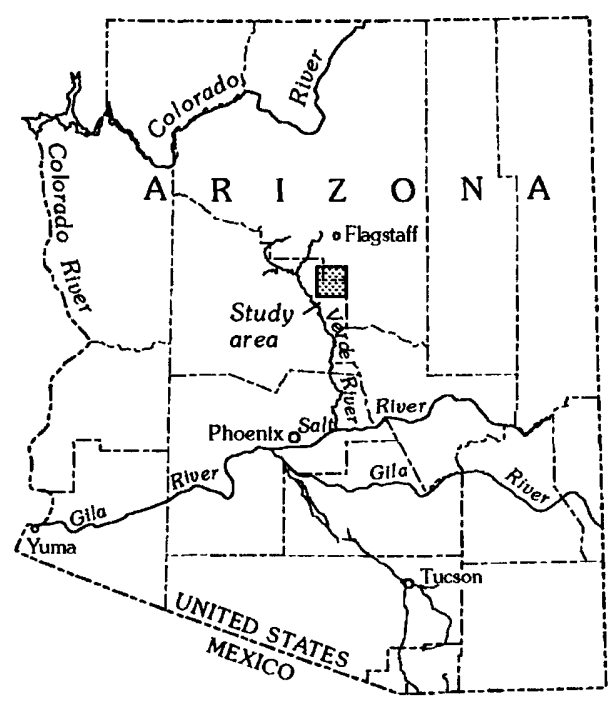

information, no reliable means can be used to assess, manage, or avert these potentially serious effects.

Objectives: Provide the National Park Service with water-resources data and information required to effectively protect the water-related aspects of Montezuma Well. These objectives are to (1) define the ground-water flow system that provides water to or that might otherwise affect Montezuma Well, including the recharge area(s), the directions of water movement and quantities of water flowing within the system; (2) provide well- and spring-location and ground-water-level maps of the flow system; (3) determine age of the water discharging into Montezuma Well and the general water-quality characteristics of the aquifer system; (4) design a monitoring network that will provide an early warning of potential disruption of the flow or adverse changes in the water quality that would affect Montezuma Well; (5) assess current and potential effects on the groundwater system caused by withdrawals from the system; and (6) provide a method that can be used to evaluate and describe effects on the aquifer system caused by future ground-water development, land-use practices, and changes in water quality. When accomplished, these objectives will provide a hydrologic characterization of the ground-water system that can be used to support and maintain Montezuma Well.

Approach: The approach and methods to be used during the project include (1) inventory and create a data base of wells, springs, and water use; (2) collect and compile available geologic information for the ground-water system to define the areal extent and boundaries of the individual water-bearing units within the area; (3) collect and analyze water samples to determine waterquality characteristics within the aquifer system and the age of the water discharging from the springs into Montezuma Well; (4) use the water-level and geologic data to construct water-level map(s) and delineate aquifer system; (5) define the characteristics of the aquifers of the ground- 
water system for Montezuma Well using the well and spring discharge and the aquifer water-level response information; (6) determine the recharge and discharge areas for the aquifer system using the water-level, spring- and stream-discharge, and geologic information available; (7) determine the water budget for the aquifer system; (8) construct a ground-water flow model of the system; (9) use the model to illustrate effects of current and probable future stress; (10) design a ground-water monitoring network that can be installed and used to provide data on possible changing flow patterns.

Progress and Significant Results, Fiscal Years 1990-91: Montezuma Well was explored extensively in May 1991. Wells and springs penetrating or issuing from various geologic formations in the study area were sampled. A well and spring data base was created for the study area.

Plans for Next Year: Data analysis and report writing. 


\section{Extent and Nature of Flood Hazards in Distributary-Flow Areas in Maricopa County, Arizona (AZ124)}

Location: Maricopa County, Arizona

Project Chief: Hjalmar W. Hjalmarson

Period of Project: January 1991 to September 1992

Cooperating Agencies: Arizona Department of Water Resources and Flood Control District of Maricopa County

Problem: Many distributary-flow areas in Maricopa County behave differently than the alluvial-fan areas described in existing Federal Emergency Management Agency (FEMA) guidelines. The detailed methodology given by FEMA in their latest guidelines is for alluvial fans

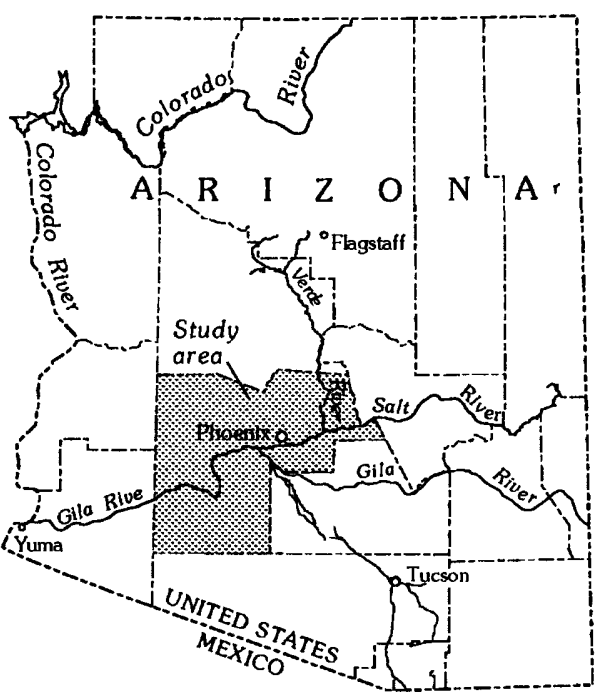
with random-flow paths, but many distributary-flow areas do not appear to have random-flow paths.

Objective: Characterize the nature of flood hazards using maps and photographs, hydraulic geometry at stream channels, and sediment erosion and deposition of distributary-flow areas for about 15 sample sites in southwestern deserts.

Approach: Obtain photographs of the channel characteristics at the primary diffluence and downstream where the channels are free to form, cross-section geometry at primary diffluence and downstream where channels are free to form, and samples of channel material. Define regime equations and compare with region equations assumed by Dawdy. Using maps and photographs, describe in detail how to apply methods of defining the degree of flood hazard.

Progress and Significant Results, Fiscal Year 1991: Obtained ground and oblique areal photographs of 15 sites and surveyed channel cross sections.

Plans for Next Year: Complete field reconnaissance of about 15 sites and document physiographic characteristics and potential flood hazards. Complete report. 
Location: Roosevelt Lake

Project Chief: Lisa K. Ham

Period of Project: October 1990 to September 1992

Cooperating Agency: Arizona Department of Environmental Quality

Problem: The Salt and Verde River reservoir system is the principal water source for the Phoenix metropolitan area. Roosevelt Lake is the largest reservoir in the system and is threatened by contamination from upstream mining operations.

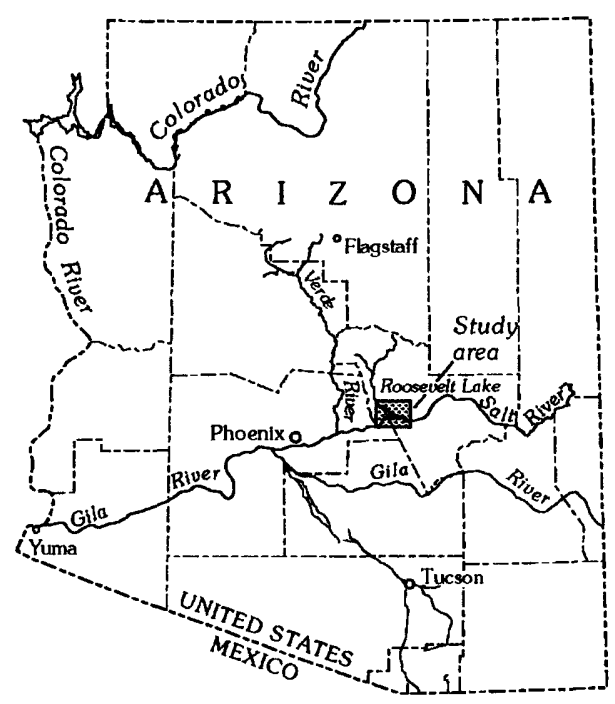

Objectives: (1) Develop a data-collection program. (2) Estimate hydrologic, sediment, and chemical budgets from historical data. (3) Evaluate, on reconnaissance level, the extent and concentration of trace metals in the upper layers of bottom material. (4) Evaluate the spatial and temporal distribution of physical and chemical conditions.

Approach: A solute budget will be computed using historical data. An 18-month limnological reconnaissance survey of the lake will be made to establish baseline conditions for major constituents, nutrients, and trace metals in the water column. Baseline conditions for bottom sediments will be established from trace metals.

Progress and Significant Results, Fiscal Years 1990-91: Completed literature search and computed solute budget. Selected sampling sites and developed water-quality sampling plans. Sampling was done in April and August 1991 for water quality and bottom sediment.

Plans for Next Year: Water-quality sampling is scheduled for December 1991 and March 1992. Hydrolab surveys are scheduled for November 1991, February 1992, and May 1992. The report will be completed by July 1992 . 


\section{Signature and Mapping of Nitrates in Ground Water \\ in West Salt River Valley (AZ126)}

Location: Central Arizona

Project Chief: James G. Brown

Period of Project: October 1990 to September 1993

\section{Cooperating Agency: Arizona Department of Environmental Quality}

Problem: Ground-water contamination in West Salt River Valley may cause adverse health effects. Reliable and reproducible techniques are needed to determine the source and spatial extent of contamination in ground water to aid in development

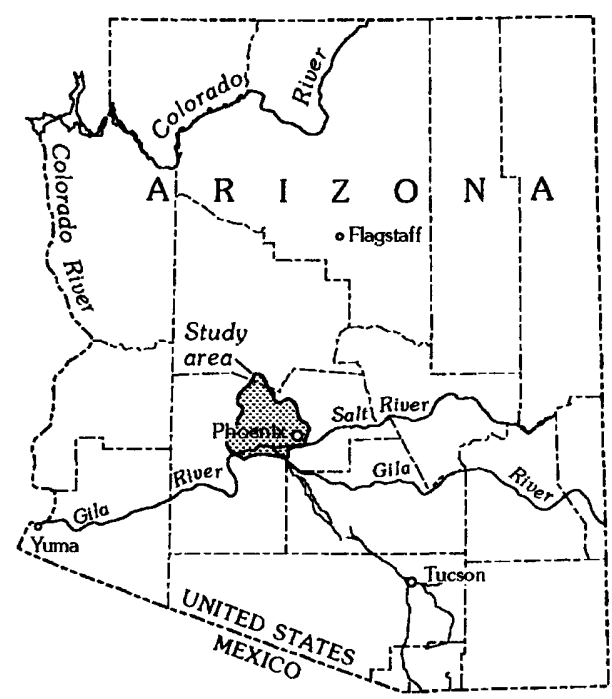
of management strategies to deal with the contamination.

Objectives: (1) Develop a geochemical technique to identify sources of contaminants (signature) through an analysis of chemical composition of potential source types and associated ground water and (2) establish the best geostatistical methods for unbiased and reproducible spatial estimates (mapping) of existing contamination of ground water.

Approach: Sampling of various potential sources and nearby affected water wells, combined with interpretation of present- and historical-data sets, will be used to establish the best methods for signature identification and mapping of contamination in ground water. The analyses of all water samples will include common ions, macronutrients, field $\mathrm{pH}$, dissolved and total organic carbon, metals, metalloids, and isotopes of nitrogen, sulfur, oxygen, hydrogen, boron, lithium, and strontium. Geostatistical techniques will be applied to the macronutrient, water chemistry, and isotope content of present and historical analyses to establish signatures for source types of agricultural and municipal ground-water nitrate. Kriging and cokriging will be applied for mapping of chemical constituents and signature attributes. In addition to testing new applications of geostatistics and interpreting chemical data, this study will involve the innovative application of nitrogen, sulfur, hydrogen, oxygen, boron, lithium, and strontium isotopes in contaminantsignature definition.

Progress and Significant Results, Fiscal Years 1990-91: Ground-water, surface-water, fertilizer, and sewage-outflow sampling was completed during summer 1991. Preliminary factor analysis was completed, which identified several major chemical constituents that are statistically related to the distribution of nitrate in ground water in West Salt River Valley. Preliminary 
analysis of selected stable isotopes has been completed, and the data indicate that the isotopes of boron and lithium may be useful in determining the origin of ground water in the valley.

Plans for Next Year: Complete kriging, cokriging, and statistical analysis of 1975, 1980-85, and 1986-90 data sets. Continue analysis of isotope data. Begin report writing. 


\section{Flood-Model Assessment and Water-Quality Characterization of Urban Runoff, Maricopa County, Arizona (AZ127)}

Location: Maricopa County, Arizona

Project Chief: Thomas J. Lopes

Period of Project: April 1991 to September 1993

Cooperating Agency: Flood Control District of Maricopa County

Problem: The Flood Control District of Maricopa County has produced a manual to help technical designers estimate storm-water runoff for the purpose of designing storm-water drainage facilities. The procedures and methods described in the manual need to be assessed by comparing predicted and observed

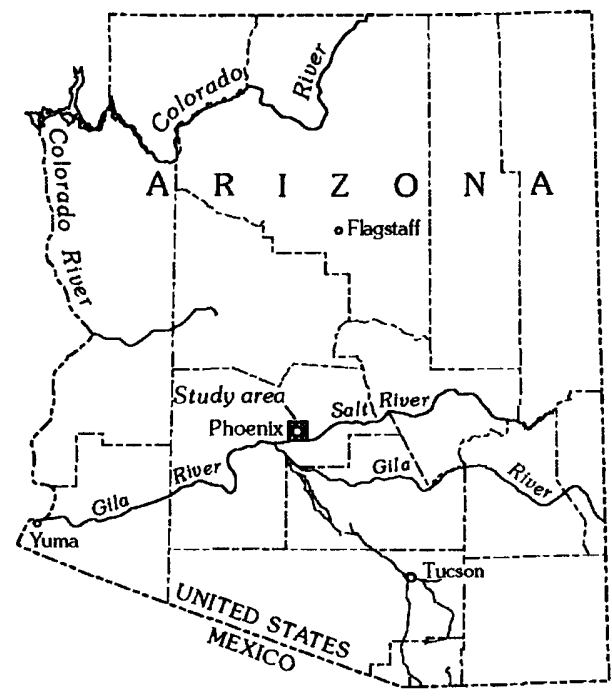
discharges. Also, the U.S. Environmental Protection Agency, under section 402(p) of the Water Quality Act of 1987, requires municipalities with a population of 100,000 or greater to obtain National Pollution Discharge Elimination System permits for storm-water discharge. Final rules published in 1990 require that the affected municipalities prepare a permit application that includes estimation of storm and annual pollutant loadings for all storm outfalls in the reporting area, most of which will be unmonitored.

Objectives: (1) Collect rainfall, runoff, and water-quality data to test urban-runoff models and characterize storm-water quality. (2) Assess whether procedures presented in the manual can predict runoff from urbanized areas and compare results of other rainfall-runoff models with results from the manual. (3) Estimate regionwide storm mean concentrations and annual loads of selected pollutants. (4) Design a monitoring program to characterize storm-runoff quality and allow estimation of storm and annual pollutant loadings.

Approach: Five basins will be selected to characterize storm runoff. Each basin will be instrumented to gage and collect samples of runoff. Procedures and methods in the manual will be used to predict hydrographs; actual hydrographs will be compared with predicted hydrographs using rainfall-runoff models. Statistical techniques developed during the National Urban Runoff Program will be used to estimate concentrations and load of pollutants. A long-term monitoring program to comply with permit requirements will be designed using experience and data collected during this study.

Progress and Significant Results, Fiscal Year 1991: Instrumented four sites, in process of obtaining clearance for fifth site, calibrated all instruments, finished program for automatic flowweighted sampling and alerting hydrologist that a site is active, and collected first sample. Wrote annotated outlines for reports and started methods and site-description sections of reports. 
Plans for Next Year: Continue collecting runoff data and samples, assess flood-model procedures and compare models, develop statistical equations relating water quality to land characteristics and runoff, integrate land-use data into a Geographic Information System, and apply equations to estimate regionwide water quality. 


\section{Investigation of Sediment Transport in Ephemeral Rivers of Maricopa County, Arizona (AZ128)}

Location: Central Arizona

Project Chief: John T.C. Parker

Period of Project: October 1990 to September 1992

Cooperating Agency: Flood Control District of Maricopa County

Problem: Sediment-transport data on large, ephemeral rivers of the Southwest are sparse. Data are needed for model input to meet local government planning obligations. Collection is hampered by the nature of hydrologic regime, hazardous conditions, and technical

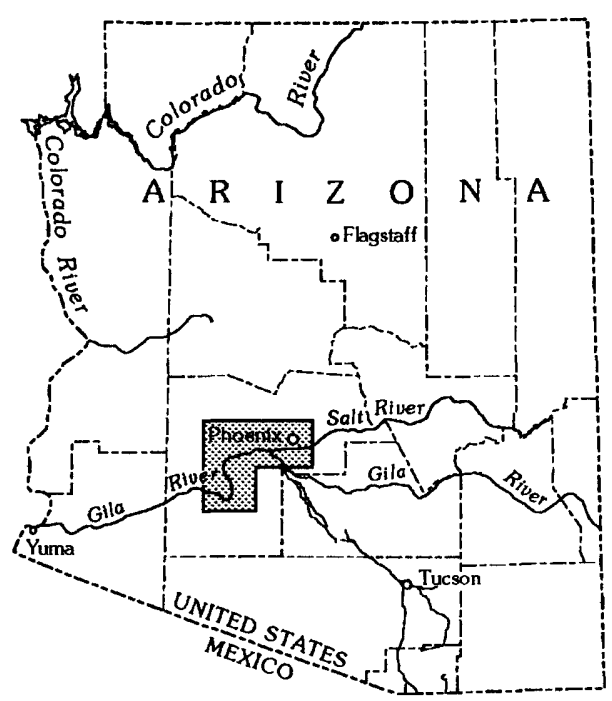
problems at high discharges.

Objectives: (1) Establish stations for long-term monitoring of sediment transport and channel changes on the Salt and Hassayampa Rivers. (2) Determine sediment discharge-stage relation, depth of active bed layer, and water-surface slope. (3) Characterize channel morphology and bed material. (4) Assess feasibility of using historical data to estimate sediment transport during floods.

Approach: (1) Use standard sampling methods during floods for suspended-sediment and discharge data. (2) Sample and analyze size of bed material and survey channel geometry to characterize study reaches. (3) Resurvey channel and resample bed material after floods to assess channel changes. (4) Analyze aerial photographs and conduct field reconnaissance of lower Gila River to determine feasibility of historical-geomorphic study.

Progress and Significant Results, Fiscal Years 1990-91: Most of the equipment has been purchased and installation has begun. The work scheduled has been planned. Aerial and ground reconnaissance of the field area is completed, and collection of stratigraphic and historical data was begun.

Plans for Next Year: Complete equipment installation and collect stratigraphic and historical data. 


\section{Geochemical Investigation in and near Abandoned Uranium Mines, Cameron and Monument Valley Mining Districts (AZ129)}

Location: Northeastern Arizona

Project Chief: Steve A. Longsworth

Period of Project: August 1991 to September 1992

Cooperating Agency: The Navajo Nation

Problem: Uranium was mined in the Cameron area from late 1950 to 1963 and at Moonlight Mine in Monument Valley from 1955 to 1969 . The surface pits were not reclaimed, and some have filled with water, which presents potential health hazards. The Navajo Nation Abandoned Mine Lands Reclamation Department (NAMLRD) is developing pit-reclamation plans that include selective and nonselective burial of

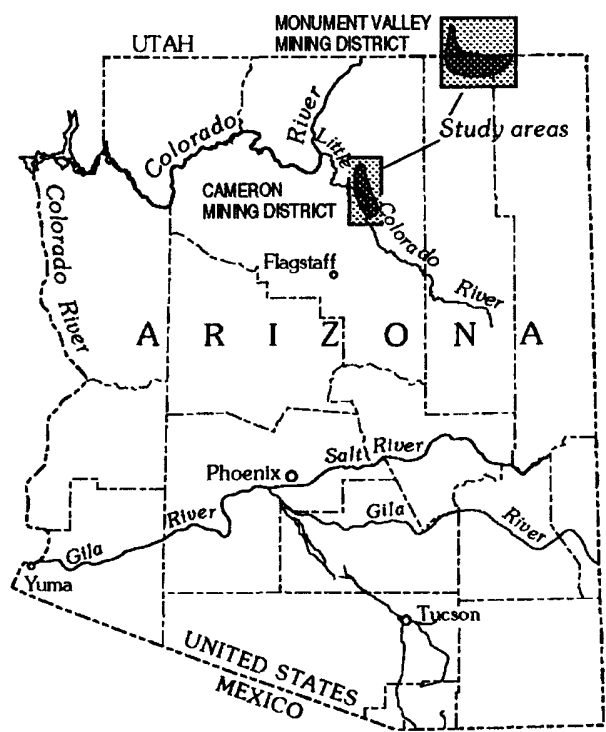
mine-spoil material on the basis of naturally occurring radioactivity. An assessment of selected geochemical properties of uranium-mine-pit water, nearby shallow ground water, and mine-spoil material is proposed to be executed by the USGS in cooperation with the NAMLRD to identify the possible effects of pit reclamation on shallow ground-water quality.

Objectives: (1) Characterize water chemistry in selected pits and in shallow ground water in the vicinity of these pits based on historical and newly acquired data. (2) Formulate conceptual models of the hydrologic system near the selected pits. (3) Provide cooperator with data from batch leaching tests and qualify the factors contributing to limitations in application of test results to field environments.

Approach: Water samples will be collected from about 10 pits, shallow drive points, and existing wells and springs near these pits. About 30 water samples will be analyzed for physical and (or) chemical characteristics. About 40 spoil samples will be selected for batch leaching and analyzed for selected radionuclides. Basic analysis of combined historical and newly acquired water-quality data will be performed. A water-resources investigations report documenting the results of the study will be prepared.

Progress and Significant Results, Fiscal Year 1991: Completed reconnaissance trip to study area to identify possible sampling locations and record general conditions of mine sites. Completed work plan and began literature search of subject material.

Plans for Next Year: Remaining work on project to be completed. Water-resources investigations report will be prepared. 
Location: Upper Verde River headwaters

Project Chief: Laurie Wirt

Period of Project: April 1991 to September 1993

Cooperating Agency: Bureau of Reclamation

Problem: The source of ground water to base flow in the upper Verde River is unknown. At least four rock formations and several major faults are exposed in the channel near the springs supplying base flow. Ground water may ultimately be derived from adjacent alluvial aquifers. An investigation is needed to determine the

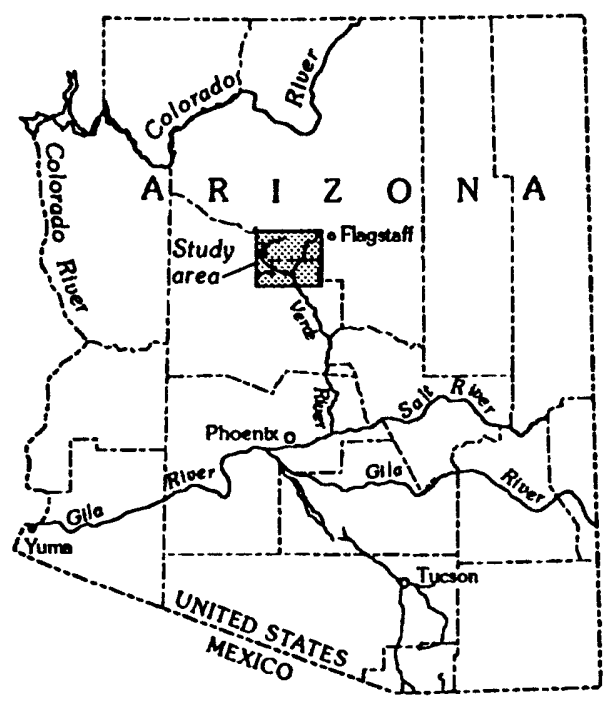
geochemical evaluation and source, or sources, of the springs.

Objective: Determine whether the alluvial aquifer underlying Big Chino Valley contributes a significant amount of water to springs that supply base flow in the upper Verde River.

Approach: Geochemistry and isotope hydrology will be used to determine the hydrologic relations among (1) base flow in the Verde River, (2) surface water in Walnut Creek and Big Chino Wash, and (3) water from the northern Big Chino alluvial aquifer and other major water-bearing geologic units that may possibly serve as sources to Verde River base flow.

Progress and Significant Results, Fiscal Year 1991: Water-quality samples were collected and a seepage run was done in July 1991. Ground-water samples were collected at 16 wells and springs during August and September 1991.

Plans for Next Year: Interpret geochemistry and isotope hydrology as soon as laboratory results are available. Publish open-file data report and journal article. 
Collection and Analysis of Ground-Water Samples from Four Monitor Wells at Davis-Monthan Air Force Base, Tucson, Arizona (AZ131)

Location: Tucson, Arizona

Project Chief: Christopher F. Smith

Period of Project: June 1991 to September 1993

Cooperating Agency: Corps of Engineers

Problem: Four monitor wells were installed near two landfills on Davis-Monthan Air Force Base as part of a U.S. Air Force Installation Restoration Program (IRP) investigation. The wells were used by the Air Force in an attempt to identify the amount and type of groundwater contamination near the landfills.

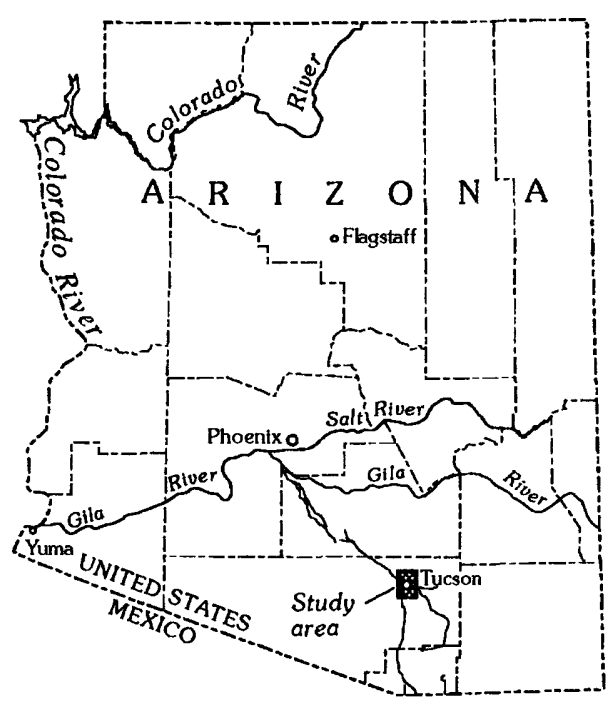

Objectives: USGS will collect and analyze water samples from the four monitor wells at DavisMonthan Air Force Base and provide annual reports that include the results of the laboratory analysis. The data collection is in compliance with IRP final decision documents.

Approach: Samples will be collected from the four monitor wells quarterly for $1-1 / 2$ years and biannually for 1 year, and samples will be analyzed

Progress and Significant Results, Fiscal Year 1991: One set of water samples was collected.

Plans for Next Year: Collect quarterly water samples and produce annual report for 1991. 


\section{BIBLIOGRAPHY}

\section{REPORTS FOR ARIZONA PUBLISHED IN FISCAL YEARS 1984-91}

Aldridge, B.N., 1985, Streamflow losses in the Santa Cruz River, Arizona, in Keyes, C.G., Jr., and Ward, T.J., eds., Development and Management Aspects of Irrigation and Drainage Systems: Specialty Conference, Irrigation and Drainage Division of the American Society of Civil Engineers, San Antonio, Texas, July 17-19, 1985, Proceedings, p. 75-83.

Aldridge, B.N., and Eychaner, J.H., 1984, Floods of October 1977 in southern Arizona and March 1978 in central Arizona: U.S. Geological Survey Water-Supply Paper 2223, 143 p.

Aldridge, B.N., and Hales, T.A., 1984, Floods of November 1978 to March 1979 in Arizona and west-central New Mexico: U.S. Geological Survey Water-Supply Paper 2241, 149 p.

Anderson, S.R., 1987, Cenozoic stratigraphy and geologic history of the Tucson basin, Pima County, Arizona: U.S. Geological Survey Water-Resources Investigations Report 87-4190, 20 p.

1988, Potential for aquifer compaction, land subsidence, and earth fissures in the Tucson basin, Pima County, Arizona: U.S. Geological Survey Hydrologic Investigations Atlas HA-713, 3 sheets.

1989, Potential for aquifer compaction, land subsidence, and earth fissures in Avra Valley, Pima and Pinal Counties, Arizona: U.S. Geological Survey Hydrologic Investigations Atlas HA-718, 3 sheets.

Anderson, T.W., 1983, Implications of deep percolation to ground-water systems in south-central Arizona based on numerical-model studies, in Deep Percolation Symposium, Scottsdale, Arizona, October 26, 1982, Proceedings: Arizona Department of Water Resources Report 4, p. 30-40.

1984, Southwest Alluvial Basins, RASA study-An overview, in Replogle, J.A., and Renard, K.G., eds., Water today and tomorrow: Specialty Conference, Irrigation and Drainage Division of the American Society of Civil Engineers, Flagstaff, Arizona, July 24-26, 1984, Proceedings, p. 606-613.

1985, Aquifer characteristics and hydrologic processes in alluvial basins of south-central Arizona, U.S.A., in Improvements in the use of ground water in agriculture: Second International Conference, Torreon, Coah., Mexico, March 13-14, 1985, p. 87-104.

1986, Geohydrology of the Southwest Alluvial Basins, Arizona, in Anderson, T.W., and Johnson, A.I., eds., Regional Aquifer Systems of the United States, Southwest Alluvial Basins of Arizona: American Water Resources Association Monograph Series 7, p. 99-111. 
1986, Hydrologic setting, objectives, and approach of the Southwest Alluvial Basins, RASA study, in Anderson, T.W., and Johnson, A.I., eds., Regional Aquifer Systems of the United States, Southwest Alluvial Basins of Arizona: American Water Resources Association Monograph Series 7, p. 5-16.

1986, Study in southern and central Arizona and parts of adjacent states, in Sun, Ren Jen, ed., Regional Aquifer-System Analysis Program of the U.S. Geological Survey, Summary of Projects, 1978-84: U.S. Geological Survey Circular 1002, p. 116-131.

Anderson, T.W., Freethey, G.W., and Tucci, Patrick, 1990, Geohydrology and water resources of alluvial basins in south-central Arizona and parts of adjacent states: U.S. Geological Survey Open-File Report 89-378, 99 p.

Anderson, T.W., Welder, G.E., Lesser, Gustavo, and Trujillo, A., 1988, Region 7, Central Alluvial Basins, in Back, William, Rosenshein, J.S., and Seaber, P.R., eds., The Geology of North America-Hydrogeology: Boulder, Colorado, Geological Society of America, Inc., v. O-2, p. 81-86.

Anderson, T.W., and White, N.D., 1986, Arizona surface-water resources, in Moody, D.W., Chase, E.B., and Aronson, D.A., compilers, National Water Summary 1985-Hydrologic Events and Surface-Water Resources: U.S. Geological Survey Water-Supply Paper 2300, p. $145-150$.

Babcock, Colleen, 1990, Ground-water edit program, in National Water Information System User's Manual, v. 2, Chap. 4, Ground-Water Site Inventory System: U.S. Geological Survey Open-File Report 89-587, p. 6-1 to 6-12.

1990, Ground-water update program, in National Water Information System User's Manual, v. 2, Chap. 4, Ground-Water Site Inventory System: U.S. Geological Survey Open-File Report 89-587, p. 7-1 to 7-12

1990, Error messages, in National Water Information System User's Manual, v. 2, Chap. 4, Ground-Water Site Inventory System: U.S. Geological Survey Open-File Report 89-587, p. 14-1 to $14-16$.

Babcock, Colleen, Luckey, R.R., Morgan, C.O., and Stephens, D.M., 1990, Ground-Water Site Inventory Coding Instructions, in National Water Information System User's Manual, v. 2, Chap. 4, Ground-Water Site Inventory System: U.S. Geological Survey Open-File Report $89-587$, p. 2-1 to 2-124.

Baldys, Stanley, III, 1990, Trend analysis of selected water-quality constituents in the Verde River basin, central Arizona: U.S. Geological Survey Water-Resources Investigations Report 90-4128, 55 p.

Baldys, Stanley, III, and Bayles, J.A., 1990, Flow characteristics of streams that drain the Fort Apache and San Carlos Indian Reservations, east-central Arizona, 1930-86: U.S. Geological Survey Water-Resources Investigations Report 90-4053, 59 p. 
Bedinger, M.S., Anderson, T.W., and Langer, W.H., 1984, Maps showing ground-water units and withdrawal, Basin and Range Province, Arizona: U.S. Geological Survey WaterResources Investigations Report 83-4114-A, 2 sheets.

Bills, D.J., and Hjalmarson, H.W., 1990, Estimates of ground-water flow components for Lyman Lake, Apache County, Arizona, with a section on Geochemistry of surface water and ground water in the Lyman Lake area, by F.N. Robertson: U.S. Geological Survey Water-Resources Investigations Report 89-4151, 55 p.

Blee, J.W.H., 1988, Determination of evaporation and seepage losses, upper Lake Mary near Flagstaff, Arizona: U.S. Geological Survey Water-Resources Investigations Report $87-4250,39 \mathrm{p}$.

Blee, J.W.H., Herlong, H.E., Kauffman, D.C., Jr., Hardee, J.H., Field, M.L., and Middelburg, R.F., Jr., 1986, GOES data-collection system instumentation, installation, and maintenance manual: U.S. Geological Survey Open-File Report 86-479, 171 p.

Boner, F.C., Blee, J.W.H., and Shope, W.G., Jr., 1985, Satellite data-relay activities in Arizona: U.S. Geological Survey Water-Resources Investigations Report 85-4158, 22 p.

Boner, F.C., Garrett, W.B., and Konieczki, A.D., 1989, Water resources data for Arizona, water year 1988: U.S. Geological Survey Water-Data Report AZ-88-1, 391 p.

Boner, F.C., Smith, C.F., Garrett, W.B., and Konieczki, A.D., 1990, Water resources data for Arizona, water year 1989: U.S. Geological Survey Water-Data Report AZ-89-1, 383 p.

Bradley, M.D., and Carpenter, M.C., 1986, Subsiding land and falling ground-water tables: Public policy, private liability, and legal remedy: Economic Geography, v. 62, no. 3, July 1986, p. 241-253.

Brown, J.G., 1989, Geology and ground-water resources of the San Carlos Indian Reservation, Gila, Graham, and Pinal Counties, Arizona: U.S. Geological Survey Water-Resources Investigations Report 89-4152, 39 p.

1990, Chemical, geologic, and hydrologic data from the study of acidic contamination in the Miami Wash-Pinal Creek area, Arizona, water years 1988-89: U.S. Geological Survey Open-File Report 90-395, 75 p.

1991, Particle-tracking analysis of flow in the stream-aquifer system in Pinal Creek basin, Arizona, in Mallard, G.E., and Aronson, D.A., eds., U.S. Geological Survey Toxic Substances Hydrology Program-Proceedings of the technical meeting, Monterey, California, March 11-15, 1991: U.S. Geological Survey Water-Resources Investigations Report 91-4034, p. 448-453.

Brown, J.G., and Eychaner, J.H., 1988, Simulation of five ground-water withdrawal projections for the Black Mesa area, Navajo and Hopi Indian Reservations, Arizona: U.S. Geological Survey Water-Resources Investigations Report 88-4000, 51 p. 
Brown, J.G., and Pool, D.R., 1989, Hydrogeology of the western part of the Salt River Valley area, Maricopa County, Arizona: U.S. Geological Survey Water-Resources Investigations Report 88-4202, 5 sheets.

Brown, P.W., and Owen-Joyce, S.J., 1991, Remote sensing and evapotranspiration estimatesInfluence of ground-based meteorological data, in Kirby, W.H., and Tan, W.Y., Proceedings of the United States-People's Republic of China Bilateral Symposium on Droughts and Arid-Region Hydrology, Tucson, Arizona, September 16-20, 1991: U.S. Geological Survey Open-File Report 91-244, p. 161-166.

Brown, P.W., Owen-Joyce, S.J., Daughtry, C.S.T., and Kustus, W.P., 1990, Effect of underlying surface on ground-based environmental data collected in an arid region [abs.], in Agronomy Abstracts, 1990 Annual Meetings, American Society of Agronomy, Crop Science Society of America, Soil Science Society of America, San Antonio, Texas, October 21-26, 1990, p. 15.

Callahan, J.L., 1990, Illustration capabilities of a computer graphics system [abs.], in Balthrop, B.H., and Baker, E.G., compilers, 1990, U.S. Geological Survey, National Computer Technology Meeting, Program and Abstracts, San Antonio, Texas, May 7-11, 1990: U.S. Geological Survey Open-File Report 90-161, p. 9.

Carpenter, M.C., 1987, Water-level declines, land subsidence, and specific compaction near Apache Junction, south-central Arizona: U.S. Geological Survey Water-Resources Investigations Report 86-4071, 22 p.

1988, Land-surface deformation and water-level fluctuations near the Picacho earth fissure, south-central Arizona, 1980-84: U.S. Geological Survey Open-File Report $88-97,24 \mathrm{p}$.

1989, Earth-fissure movements associated with fluctuations in ground-water levels, south-central Arizona, 1980-84 [abs.]: 28th International Geological Congress, Washington, D.C., July 9-19, 1989, Abstracts, v. 1, p. 243.

1991, Earth-fissure movements associated with fluctuations in ground-water levels near the Picacho Mountains, south-central Arizona, 1980-84: U.S. Geological Survey Open-File Report 90-561, 64 p.

Carpenter, M.C., and Bradley, M.D., 1984, Legal perspectives on subsidence caused by groundwater withdrawal in Texas, California, and Arizona, U.S.A., in Land Subsidence: Third International Symposium on Land Subsidence, Venice, Italy, March 19-25, 1984, Proceedings, p. 817-828.

Carpenter, M.C., Hanson, R.T., and Riley, F.S., 1987, An averaging temperature sensor to correct measurements of aquifer compaction for interaquifer borehole flow [abs.]: Eos Transactions, American Geophysical Union, v. 68, no. 44, November 3, 1987, p. 1300. 
Cuff, M.K., 1984, Map showing geohydrologic conditions in the Vekol Valley, Pinal and Maricopa Counties, Arizona-1983: U.S. Geological Survey Water-Resources Investigations Report 84-4270, 1 sheet.

Cuff, M.K., and Anderson, S.R., 1987, Ground-water conditions in Avra Valley, Pima and Pinal Counties, Arizona-1985: U.S. Geological Survey Water-Resources Investigations Report 87-4192, 3 sheets.

Epstein, V.J., 1987, Hydrologic and geologic factors affecting land subsidence near Eloy, Arizona: U.S. Geological Survey Water-Resources Investigations Report 87-4143, 28 p.

Eychaner, J.H., 1983, Geohydrology and effects of water use in the Black Mesa area, Navajo and Hopi Indian Reservations, Arizona: U.S. Geological Survey Water-Supply Paper 2201, $26 \mathrm{p}$.

1983, Comparison of flood-frequency estimates in southern Arizona [abs.]: Eos Transactions, American Geophysical Union, v. 64, no. 45, November 8, 1983, p. 706-707.

1984, Estimation of magnitude and frequency of floods in Pima County, Arizona, with comparisons of alternative methods: U.S. Geological Survey Water-Resources Investigations Report 84-4142, 69 p.

1986, Discussion of "Probable maximum flood estimation-Eastern United States," by P.B. Ely and J.C. Peters, in Water Resources Bulletin, v. 22, no. 1: American Water Resources Association, p. 137.

1988, Evolution of acidic ground-water contamination in a copper-mining area in Arizona, in Ouazar, D., Brebbia, C.A., and Stout, G.E., eds., Water Quality, Planning, and Management: New York, Springer-Verlag, v. 6, Computer Methods and Water Resources, First International Conference, Morocco, 1988, Proceedings, p. 291-302.

1989, Movement of inorganic contaminants in acidic water near Globe, Arizona, in Mallard, G.E., and Ragone, S.E., eds., U.S. Geological Survey Toxic Substances Hydrology Program-Proceedings of the Technical Meeting, Phoenix, Arizona, September 26-30, 1988: U.S. Geological Survey Water-Resources Investigations Report 88-4220, p. 567-575.

1989, Research activities related to acidic water near Globe, Arizona, in Mallard, G.E., and Ragone, S.E., eds., U.S. Geological Survey Toxic Substances Hydrology Program-Proceedings of the Technical Meeting, Phoenix, Arizona, September 26-30, 1988: U.S. Geological Survey Water-Resources Investigations Report 88-4220, p. 599-601.

1991, Inorganic contaminants in acidic water near Globe, Arizona, in Survival in the Desert-Water Quality and Quantity Issues into the 21st Century: Arizona Hydrological Society, Third Annual Symposium, Casa Grande, Arizona, September 20-22, 1990, Proceedings, p. 242-252. 
1991, Solute transport in perennial streamflow at Pinal Creek, Arizona, in Mallard, G.E., and Aronson, D.A., eds., U.S. Geological Survey Toxic Substances Hydrology Program-Proceedings of the technical meeting, Monterey, California, March 11-15, 1991: U.S. Geological Survey Water-Resources Investigations Report 91-4034, p. 481-485.

1991, The Globe, Arizona, research site-Contaminants related to copper mining in a hydrologically integrated environment, in Mallard, G.E., and Aronson, D.A., eds., U.S. Geological Survey Toxic Substances Hydrology Program-Proceedings of the technical meeting, Monterey, California, March 11-15, 1991: U.S. Geological Survey Water-Resources Investigations Report 91-4034, p. 439-447.

Eychaner, J.H., Rehmann, M.R., and Brazel, A.J., 1991, Arizona floods and droughts, in National Water Summary 1988-89-Hydrologic events and floods and droughts: U.S. Geological Survey Water-Supply Paper 2375, p. 171-180.

Eychaner, J.H., Rehmann, M.R., and Brown, J.G., 1989, Chemical, geologic, and hydrologic data from the study of acidic contamination in the Miami Wash-Pinal Creek area, Arizona, water years 1984-87: U.S. Geological Survey Open-File Report 89-410, 105 p.

Eychaner, J.H., and Stollenwerk, K.G., 1985, Neutralization of acidic ground water near Globe, Arizona, in Schmidt, K.D., ed., Symposium on groundwater contamination and reclamation, Tucson, Arizona, August 14-15, 1985, Proceedings: American Water Resources Association, August 1985, p. 141-148.

Faires, L.M., and Eychaner, J.H., 1991, Trace-element trends at Pinal Creek, Arizona, in Mallard, G.E., and Aronson, D.A., eds., U.S. Geological Survey Toxic Substances Hydrology Program-Proceedings of the technical meeting, Monterey, California, March 11-15, 1991: U.S. Geological Survey Water-Resources Investigations Report 91-4034, p. 461-465.

Fields, R.L., 1986, Data-processing activities of the Southwest Alluvial Basins, RASA study, in Anderson, T.W., and Johnson, A.I., eds., Regional Aquifer Systems of the United States, Southwest Alluvial Basins of Arizona: American Water Resources Association Monograph Series 7, p. 17-23.

Fields, R.L., and Vetter, E.F., 1984, A data-management system for use in ground-water modeling and resource evaluation: U.S. Geological Survey Water-Resources Investigations Report 84-4014, 277 p.

Freethey, G.W., 1984, Ground-water modeling, alluvial basins of Arizona, in Replogle, J.A., and Renard, K.G., eds., Water today and tomorrow: Specialty Conference, Irrigation and Drainage Division of the American Society of Civil Engineers, Flagstaff, Arizona, July 24-26, 1984, Proceedings, p. 675-682.

1986, Considerations in modeling ground-water flow in the alluvial basins of Arizona, in Anderson, T.W., and Johnson, A.I., eds., Regional Aquifer Systems of the 
United States, Southwest Alluvial Basins of Arizona: American Water Resources Association Monograph Series 7, p. 57-67.

Freethey, G.W., and Anderson, T.W., 1986, Predevelopment hydrologic conditions in the alluvial basins of Arizona and adjacent parts of California and New Mexico: U.S. Geological Survey Hydrologic Investigations Atlas HA-664, 3 sheets.

Freethey, G.W., Pool, D.R., Anderson, T.W., and Tucci, Patrick, 1986, Description and generalized distribution of aquifer materials in the alluvial basins of Arizona and adjacent parts of California and New Mexico: U.S. Geological Survey Hydrologic Investigations Atlas HA-663, 4 sheets.

Garrett, J.M., and Gellenbeck, D.J., 1991, Basin characteristics and streamflow statistics in Arizona as of 1989: U.S. Geological Survey Water-Resources Investigations Report 91-4041, 612 p.

Garrett, J.M., Roeske, R.H., and Bryce, B.N., 1986, Flood of October 1983 in southeastern Arizona-Areas of inundation in selected reaches along the Gila River: U.S. Geological Survey Water-Resources Investigations Report 85-4225-A, 3 sheets.

Graf, J.B., 1986, Sediment transport under regulated flow, Colorado River, Grand Canyon National Park, Arizona: Eos Transactions, American Geophysical Union, v. 67, no. 44, p. 950.

Graf, J.B., Kieffer, S.W., and Schmidt, J.C., 1989, Hydraulic log of the Colorado River from Lees Ferry to Diamond Creek, Arizona-Chapter 2, in Elston, D.P., Billingsly, G.H., and Young, R.A., eds., Geology of Grand Canyon, Northern Arizona: American Geophysical Union, Field Guide for the 28th International Geological Congress, Washington D.C., July 1989 , p. 37-47.

Graf, J.B., Pemberton, E.L., and Schmidt, J.C., 1986, Sediment studies in Grand Canyon, Arizona: Fourth Federal Interagency Sedimentation Conference, v. 2, Las Vegas, Nevada, March 24-27, 1986, Proceedings, p. 5-61 to 5-70.

Graham, D.D., 1988, Flow in the unsaturated zone, Tucson, Arizona: U.S. Geological Survey Open-File Report 88-329, Water Fact Sheet, 1 sheet.

1989, Methodology, results, and significance of an unsaturated-zone tracer test at an artificial-recharge facility, Tucson, Arizona: U.S. Geological Survey Water-Resources Investigations Report 89-4097, 28 p.

1990, Unsaturated-zone tracer test at an artificial-recharge facility, Tucson, Arizona, in Minimizing Risk to the Hydrologic Environment: American Institute of Hydrology, 1990 Spring Meeting, Program with Abstracts, Las Vegas, Nevada, March 12-16, 1990, p. 19. 
1991, Results and significance of an unsaturated-zone tracer test at an artificial-recharge basin, Tucson, Arizona [abs.]: Phoenix, Salt River Project, Fifth Biennial Symposium on Artificial Recharge of Groundwater, Tucson, Arizona, May 29-31, 1991, Proceedings, p. 169.

Gray, J.R., Lopes, T.J., and Wirt, Laurie, 1990, Water quality in uranium-mine pits and ground water in the Cameron Uranium Mining Belt, Arizona, in Minimizing Risk to the Hydrologic Environment: American Institute of Hydrology, 1990 Spring Meeting, Program with Abstracts, Las Vegas, Nevada, March 12-16, 1990, p. 19.

Gray, J.R., and McElhone, T.J., 1990, A computer program to calculate sediment-discharge records [abs.], in Balthrop, B.H., and Baker, E.G., compilers, U.S. Geological Survey National Computer Technology Meeting-Program and Abstracts, San Antonio, Texas, May 7-11, 1990: U.S. Geological Survey Open-File Report 90-161, p. 12.

Gray, J.R., Webb, R.H., and Hyndman, D.W., 1991, Low-flow sediment transport in the Colorado River, in Fan, Shou-Shan, and Kuo, Yung-Huang, eds., Proceedings of the Fifth Federal Interagency Sedimentation Conference, Las Vegas, Nevada, March 18-21, 1991: Washington, D.C., Federal Energy Regulatory Commission, v. 1, p. 4-63 to 4-71.

Hanson, R.T., 1987, One-dimensional modeling of aquifer-system compaction in south-central Arizona [abs.]: Eos Transactions, American Geophysical Union, v. 68, no. 44, November 3, 1987, p. 1300-1301.

1989, Aquifer-system compaction, Tucson basin and Avra Valley, Arizona: U.S. Geological Survey Water-Resources Investigations Report 88-4172, 69 p.

1989, Postaudit analyses of groundwater models of an alluvial-aquifer system, Avra Valley, Arizona [abs.]: 28th International Geological Congress, Washington, D.C., July 9-19, 1989, Abstracts, v. 2, p. 27.

1989, Simulation of aquifer-system compaction in south-central Arizona [abs.]: 28th International Geological Congress, Washington, D.C., July 9-19, 1989, Abstracts, v. 2, p. 27-28.

Hanson, R.T., Anderson, S.R., and Pool, D.R., 1990, Simulation of ground-water flow and potential land subsidence, Avra Valley, Arizona: U.S. Geological Survey Water-Resources Investigations Report 90-4178, 41 p.

Hart, R.J., and Sottilare, J.P., 1988, Progress report on the ground-water, surface-water, and quality-of-water monitoring program, Black Mesa area, northeastern Arizona-1987-88: U.S. Geological Survey Open-File Report 88-467, 27 p.

1989, Progress report on the ground-water, surface-water, and quality-of-water monitoring program, Black Mesa area, northeastern Arizona-1988-89: U.S. Geological Survey Open-File Report 89-383, 33 p. 
Haschenburger, J.K., 1989, Manganese in channel sediment of Pinal Creek, Arizona, in Mallard, G.E., and Ragone, S.E., eds., U.S. Geological Survey Toxic Substances Hydrology Program-Proceedings of the Technical Meeting, Phoenix, Arizona, September 26-30, 1988: U.S. Geological Survey Water-Resources Investigations Report 88-4220, p. 593-597.

Hem, J.D., and Robertson, F.N., 1987, Hydrogeochemistry of ground-water recharge in alluvial aquifers, southern Arizona, in Third Symposium on Artificial Recharge of Groundwater in Arizona, May 20-21, 1987, Proceedings: Salt River Project, p. 30-51.

Hill, G.W., 1985, Progress report on Black Mesa monitoring program-1984: U.S. Geological Survey Open-File Report 85-483, 24 p.

Hill, G.W., Hales, T.A., and Aldridge, B.N., 1988, Flood hydrology near Flagstaff, Arizona: U.S. Geological Survey Water-Resources Investigations Report 87-4210, 31 p.

Hill, G.W., and Sottilare, J.P., 1987, Progress report on the ground-water, surface-water, and quality-of-water monitoring program, Black Mesa area, northeastern Arizona-1987: U.S. Geological Survey Open-File Report 87-458, 29 p.

Hill, G.W., and Whetten, M.I., 1986, Progress report on Black Mesa monitoring program1985-86: U.S. Geological Survey Open-File Report 86-414, 23 p.

Hjalmarson, H.W., 1984, Flash flood in Tanque Verde Creek, Tucson, Arizona: American Society of Civil Engineers, Journal of Hydraulic Engineering, v. 110, no. 12, p. 1841-1852.

1988, Flood-hazard zonation in arid lands, in Arid Lands-Hydrology, scour, and water quality: Washington, D.C., National Research Council, Transportation Research Council, Record 1201, p. 1-8.

1990, Flood of October 1983 and history of flooding along the San Francisco River, Clifton, Arizona: U.S. Geological Survey Water-Resources Investigations Report 85-4225-B, 42 p.

1991, Flood hydrology of arid basins in southwestern United States, in Kirby, W.H., and Tan, W.Y., eds., Proceedings of the United States-People's Republic of China Bilateral Symposium on Droughts and Arid-Region Hydrology, Tucson, Arizona, September 16-20, 1991: U.S. Geological Survey Open-File Report 91-244, p. 59-64.

Hjalmarson, H.W., and Kemna, S.P., 1990, Flood hazards of distributary-flow areas in southern Arizona, in Minimizing Risk to the Hydrologic Environment: American Institute of Hydrology, 1990 Spring Meeting, Program with Abstracts, Las Vegas, Nevada, March 12-16, 1990, p. 20.

Hjalmarson, H.W., and Robertson, F.N., 1991, Hydrologic and geochemical approaches for determining ground-water flow components, in Ritter, W.F., ed., Irrigation and Drainage, 
Proceedings of the 1991 National Conference: New York, American Society of Civil Engineers, p. 267-274.

Hjalmarson, H.W., and Thomas, B.E., 1990, Regional flood-frequency relation for streams with many years of no flow, in French, R.H., ed., Hydraulics/Hydrology of Arid Lands: New York, American Society of Civil Engineers, International Symposium, San Diego, California, July 30-August 2, 1990, Proceedings, p. 483-488.

Hollett, K.J., 1985, Geohydrology and water resources of the Papago Farms-Great Plain area, Papago Indian Reservation, Arizona, and the upper Rio Sonoyta area, Sonora, Mexico: U.S. Geological Survey Water-Supply Paper 2258, 44 p.

Hollett, K.J., and Garrett, J.M., 1984, Geohydrology of the Papago, San Xavier, and Gila Bend Indian Reservations, Arizona-1978-81: U.S. Geological Survey Hydrologic Investigations Atlas HA-660, 2 sheets.

Hollett, K.J., and Marie, J.R., 1987, Simulation of the ground-water flow system and proposed withdrawals in the northern part of Vekol Valley, Arizona: U.S. Geological Survey Water-Resources Investigations Report 86-4340, 68 p.

Hyndman, D.W., Roberts, R.A., and Webb, R.H., 1991, Modeling sediment transport in an ephemeral river, in Fan, Shou-Shan, and Kuo, Yung-Huang, eds., Proceedings of the Fifth Federal Interagency Sedimentation Conference, Las Vegas, Nevada, March 18-21, 1991: Washington, D.C., Federal Energy Regulatory Commission, v. 2, p. 8-101 to 8-108.

Jackson, R.D., Moran, M.S., Gay, L.W., and Raymond, L.H., 1987, Evaluating evaporation from field crops using airborne radiometry and ground-based meteorological data: Irrigation Science, v. 8, p. 81-90.

Kepner, W.G., Hunter, W.C., Eddleman, W.R., and Radtke, D.B., 1990, Selenium bioaccumulation in Yuma clapper rail and other rallids from the lower Colorado River Valley [abs.], in Joint Annual Meeting of American Fisheries Society, Arizona-New Mexico Chapter of the Wildlife Society, Thatcher, Arizona, February 1-3, 1990: American Fisheries Society, p. 10.

Kieffer, S.W., Graf, J.B., and Schmidt, J.C., 1989, Hydraulics and sediment transport of the Colorado River: Chapter 3, in Elston, D.P., Billingsly, G.H., and Young, R.A., eds., Geology of Grand Canyon, Northern Arizona: American Geophysical Union, Field Guide for the 28th International Geological Congress, Washington, D.C., July 1989, p. 48-66.

Kister, L.R., Radtke, D.B., and Graf, Chuck, 1988, Arizona ground-water quality, in Moody, D.W., Carr, Jerry, Chase, E.B., and Paulson, R.W., compilers, National Water Summary 1986-Hydrologic Events and Ground-Water Quality: U.S. Geological Survey Water-Supply Paper 2325, p. 157-164.

Konieczki, A.D., and Anderson, S.R., 1990, Evaluation of ground-water recharge along the Gila River as a result of the flood of October 1983, in and near the Gila River Indian 
Reservation, Maricopa and Pinal Counties, Arizona: U.S. Geological Survey Water-Resources Investigations Report 89-4148, 30 p.

Laney, R.L., and Hahn, M.E., 1986, Hydrogeology of the eastern part of the Salt River Valley area, Maricopa and Pinal Counties, Arizona: U.S. Geological Survey Water-Resources Investigations Report 86-4147, 4 sheets.

Laney, R.L., and Pankratz, L.W., 1987, Investigations of land subsidence and earth fissures near the Salt-Gila aqueduct, Maricopa and Pinal Counties, Arizona-Altitudes of the tops of the consolidated rocks, surficial geology, and land subsidence in the Florence quadrangle: U.S. Geological Survey Miscellaneous Investigations Series Map I-1892-A, 1 sheet.

Langer, W.H., Mulvihill, D.A., and Anderson, T.W., 1984, Maps showing ground-water levels, springs, and depth to ground water, Basin and Range Province, Arizona: U.S. Geological Survey Water-Resources Investigations Report 83-4114-B, 2 sheets.

Leake, S.A., 1983, Simulation of components of ground-water flow normal to the Colorado River in the Yuma area, Arizona and California: American Geophysical Union, Front Range Branch, 3rd, Fort Collins, Colorado, 1983, Proceedings, p. 192.

1984, A method for estimating ground-water return flow to the Colorado River in the Parker area, Arizona and California: U.S. Geological Survey Water-Resources Investigations Report 84-4229, $31 \mathrm{p}$

1989, New approaches to simulating aquifer-system compaction in models of regional ground-water flow: 28th International Geological Congress, Washington, D.C., July 9-19, 1989, Abstracts, v. 2, p. 271-272.

1990, Applications of user-supplied transformations in computer-graphics programs, in Wiltshire, D.A., Selected Papers in the Applied Computer Sciences, 1990: U.S. Geological Survey Bulletin 1908, p. A1-A5.

1990, Interbed storage changes and compaction in models of regional groundwater flow: Water Resources Research, v. 26, no. 9, p. 1939-1950.

1990, Interbed storage changes and compaction in models of regional groundwater flow [abs.]: Eos Transactions, American Geophysical Union, v. 71, no. 19, May 8, 1990, p. 704.

1991, Application of user-supplied transformations in computer-graphics programs [abs.], in Balthrop, B.H., and Terry, J.E., eds., U.S. Geological Survey National Computer Technology Meeting-Proceedings, Phoenix, Arizona, November 14-18, 1988: U.S. Geological Survey Water-Resources Investigations Report 90-4162, p. 73.

1991, Simulation of vertical compaction in models of regional ground-water flow, in Johnson, Ivan, ed., Land Subsidence-Proceedings of the Fourth International 
Symposium on Land Subsidence, Houston, Texas, May 1991: International Association of Hydrological Sciences Publication No. 200, p. 565-574.

Leake, S.A., and Hanson, R.T., 1987, Distribution and movement of trichloroethylene in ground water in the Tucson area, Arizona: U.S. Geological Survey Water-Resources Investigations Report 86-4313, $40 \mathrm{p}$.

Leake, S.A., and Prudic, D.E., 1987, New approaches to simulating aquifer-system compaction in models of regional ground-water flow [abs.]: American Geophysical Union Transactions, v. 68 , no. 44 , p. 1301.

1991, Documentation of a computer program to simulate aquifer-system compaction using the modular finite-difference ground-water flow model: U.S. Geological Survey Techniques of Water-Resources Investigations, book 6, chap. A2, 68 p.

Littin, G.R., 1987, Ground-water resources of the Bisbee-Naco area, Cochise County, Arizona: U.S. Geological Survey Water-Resources Investigations Report 87-4103, 34 p.

Loeltz, O.J., and Leake, S.A., 1983, A method for estimating ground-water return flow to the lower Colorado River in the Yuma area, Arizona and California: U.S. Geological Survey Water-Resources Investigations Report 83-4220, 86 p.

1983, A method for estimating ground-water return flow to the lower Colorado River in the Yuma area, Arizona and California-Executive summary: U.S. Geological Survey Water-Resources Investigations Report 83-4221, 8 p.

Longsworth, S.A., 1991, Geohydrology and chemical quality of ground water, San Bernardino National Wildlife Refuge, Arizona: U.S. Geological Survey Water-Resources Investigations Report 90-4190, 28 p.

1991, Measurement of stream reaeration at Pinal Creek, Arizona, in Mallard, G.E., and Aronson, D.A., eds., U.S. Geological Survey Toxic Substances Hydrology ProgramProceedings of the technical meeting, Monterey, California, March 11-15, 1991: U.S. Geological Survey Water-Resources Investigations Report 91-4034, p. 492-497.

Lopes, T.J., 1991, Effects of uranium mining, Puerco River, New Mexico, in Ritter, W.F., ed., Irrigation and Drainage, Proceedings of the 1991 National Conference: New York, American Society of Civil Engineers, p. 508-515.

Mac Nish, R.D., 1985, Gains and losses of commingled waters in a stream, in Keyes, C.G., and Ward, T.J., eds., Development and management aspects of irrigation and drainage systems: Specialty Conference, Irrigation and Drainage Division of the American Society of Civil Engineers, San Antonio, Texas, July 17-19, 1985, Proceedings, p. 114-122. 
1990, Land subsidence-The process and some implications in southern Arizona: Tucson, Arizona, Water Words, Southern Arizona Water Resources Association, v. 8, no. 1, January/February 1990, p. 8-9.

1992, Scientific challenges in managing the Colorado River, in Jones, M.E., and Laenen, Antonius, eds., Interdisciplinary Approaches in Hydrology and Hydrogeology: American Institute of Hydrology, p. 31-337.

McGavock, E.H., Anderson, T.W., Moosburner, Otto, and Mann, L.J., 1986, Water resources of southern Coconino County, Arizona: Arizona Department of Water Resources Bulletin 4, $53 \mathrm{p}$.

Mann, L.J., and Rohne, P.B., Jr., 1983, Streamflow losses and changes in ground-water levels along the Salt and Gila Rivers near Phoenix, Arizona-February 1978 to June 1980: U.S. Geological Survey Water-Resources Investigations Report 83-4043, 11 p.

Marie, J.R., 1985, Streamflow losses, consequent flow through a thick unsaturated zone, and recharge to an unconfined aquifer [abs.], in Keyes, C.G., Jr., and Ward, T.J., eds., Development and management aspects of irrigation and drainage systems: Specialty Conference, Irrigation and Drainage Division of the American Society of Civil Engineers, San Antonio, Texas, July 17-19, 1985, Proceedings, p. 486-487.

Miller, B.H., and Schumann, H.H., 1986, Subsurface fault near Snyder Hill in Avra Valley, Arizona [abs.], in 30th Annual Meeting of the Arizona-Nevada Academy of Science, Glendale, Arizona, April 19, 1986: Arizona-Nevada Academy of Science, v. 21, p. 52-53.

Moran, M.S., Jackson, R.D., Raymond, L.H., Gay, L.W., and Slater, P.H., 1989, Mapping surface energy balance components by combining Landsat thematic mapper and ground-based meteorological data: Remote Sensing Environment, v. 30, p. 77-87.

Myrick, R.M., and Aldridge, B.N., 1985, Delineation of flood hazards in the Ruelas Canyon Quadrangle, Pima County, Arizona: U.S. Geological Survey Miscellaneous Investigations Series Map I-843-E, scale 1:24,000, 1 sheet.

Neaville, C.C., 1989, Simulation of ground- and surface-water flow in the Globe area, Arizona, in Mallard, G.E., and Ragone, S.E., eds., U.S. Geological Survey Toxic Substances Hydrology Program-Proceedings of the Technical Meeting, Phoenix, Arizona, September 26-30, 1988: U.S. Geological Survey Water-Resources Investigations Report 88-4220, p. 577-579.

Nelson, D.J., Webb, R.H., and Long, Austin, 1990, Analysis of stick-nest rat (Leporillus: Muridae) middens from central Australia, in Bentancourt, J.L., Van Devender, T.R., and Martin, P., eds., Fossil packrat middens--The last 40,000 years of biotic change: Tucson, Arizona, University of Arizona Press, p. 428-434. 
Owen-Joyce, S.J., 1984, A method for estimating ground-water return flow to the Colorado River in the Palo Verde-Cibola area, California and Arizona: U.S. Geological Survey Water-Resources Investigations Report 84-4236, $48 \mathrm{p}$.

1984, Hydrology of a stream-aquifer system in the Camp Verde area, Yavapai County, Arizona: Arizona Department of Water Resources Bulletin 3, 60 p.

1987, Estimates of average annual tributary inflow to the lower Colorado River, Hoover Dam to Mexico: U.S. Geological Survey Water-Resources Investigations Report 87-4078, 1 sheet.

1988, Field conditions at the Maricopa Agricultural Center, Pinal County, Arizona, June 13, 1988: U.S. Geological Survey Open-File Report 88-708, 5 p.

1988, Estimates of consumptive use and ground-water return flow using water budgets in Parker Valley, Arizona and California, 1981-84: U.S. Geological Survey Water-Resources Investigations Report 88-4063, 64 p.

1989, Field conditions at the Maricopa Agricultural Center, Pinal County, Arizona, April 9, 1989: U.S. Geological Survey Open-File Report 89-377, 14 p.

1989, Field conditions at the Maricopa Agricultural Center, Pinal County, Arizona, June 16, 1989: U.S. Geological Survey Open-File Report 89-392, 11 p.

1989, Field conditions at the Maricopa Agricultural Center, Pinal County, Arizona, September 28, 1989: U.S. Geological Survey Open-File Report 89-590, 12 p.

1990, Accounting for water use along the Colorado River, Hoover Dam to Mexico, in Minimizing Risk to the Hydrologic Environment: American Institute of Hydrology, 1990 Spring Meeting, Program with Abstracts, Las Vegas, Nevada, March 12-16, 1990, p. 22.

1990, Estimates of consumptive use and ground-water return flow and the effect of rising and sustained high river stage on the method of estimation in Cibola Valley, Arizona and California, 1983 and 1984: U.S. Geological Survey Water-Resources Investigations Report 89-4194, $41 \mathrm{p}$.

1991, Field conditions at the Maricopa Agricultural Center, Pinal County, Arizona, June 26-28, 1990: U.S. Geological Survey Open-File Report 91-461, 15 p.

Owen-Joyce, S.J., and Bell, C.K., 1983, Appraisal of water resources in the upper Verde River area, Yavapai and Coconino Counties, Arizona: Arizona Department of Water Resources Bulletin 2, $219 \mathrm{p}$.

Owen-Joyce, S.J., and Kimsey, S.L., 1987, Estimates of consumptive use and ground-water return flow using water budgets in Palo Verde Valley, California: U.S. Geological Survey Water-Resources Investigations Report 87-4070, $50 \mathrm{p}$. 
Owen-Joyce, S.J., and von Allworden, B.K., 1990, Water-budget and remote-sensing technologies combine to account for water use along the lower Colorado River [abs.], in Balthrop, B.H., and Baker, E.G., compilers, 1990, U.S. Geological Survey, National Computer Technology Meeting, Program and Abstracts, San Antonio, Texas, May 7-11, 1990: U.S. Geological Survey Open-File Report 90-161, p. 27.

Parker, J.T.C., 1989, Historic channel migration of Santa Cruz River, near Tucson, Arizona, in Abstracts with Programs, 1989: Geological Society of America, Rocky Mountain Section, 42nd Annual Meeting, and Cordilleran Section, 85th Annual Meeting, Spokane, Washington, May 8-11, 1989, v. 21, no. 5, Abstract no. 14229, p. 127.

1990, Channel-changing processes on the Santa Cruz River, Pima County, Arizona, 1936-86, in French, R.H., ed., Hydraulics/Hydrology of Arid Lands: New York, American Society of Civil Engineers, International Symposium, San Diego, California, July 30-August 2, 1990, Proceedings, p. 441-446.

1991, Temporal variability of lateral channel change on the Santa Cruz River, Pima County, Arizona [abs.]: Eos Transactions, American Geophysical Union, v. 71, no. 43 , p. 1322.

Pool, D.R., 1984, Aquifer geology of alluvial basins of Arizona, in Replogle, J.A., and Renard, K.G., eds., Water today and tomorrow: Specialty Conference, Irrigation and Drainage Division of the American Society of Civil Engineers, Flagstaff, Arizona, July 24-26, 1984, Proceedings, p. 683-690.

1986, Aquifer geology of alluvial basins of Arizona, in Anderson, T.W., and Johnson, A.I., eds., Regional Aquifer Systems of the United States, Southwest Alluvial Basins of Arizona: American Water Resources Association Monograph Series 7, p. 25-36.

1987, Hydrogeology of McMullen Valley, west-central Arizona: U.S. Geological Survey Water-Resources Investigations Report 87-4140, 51 p.

1989, Estimation of aquifer-system storage properties in an alluvial basin, south-central Arizona: 28th International Geological Congress, Washington, D.C., July 9-19, 1989, Abstracts, v. 2, p. 623.

Pool, D.R., and Hatch, Michael, 1991, Gravity response to storage change in the vicinity of infiltration basins [abs.]: Phoenix, Salt River Project, Fifth Biennial Symposium on Artificial Recharge of Groundwater, Tucson, Arizona, May 29-31, 1991, Proceedings, p. 171.

Puls, R.W., and Eychaner, J.H., 1990, Sampling of ground water for inorganics-Pumping rate, filtration, and oxidation effects, in Proceedings of the Fourth National Outdoor Action Conference on Aquifer Restoration, Ground Water Monitoring, and Geophysical 
Methods: Dublin, Ohio, Water Well Journal Publishing Company, Ground Water Management, book 2 of a series, p. 313-327.

Puls, R.W., Eychaner, J.H., and Powell, R.M., 1990, Colloidal-facilitated transport of inorganic contaminants in ground water-Part 1. Sampling considerations: Ada, Oklahoma, U.S. Environmental Protection Agency, Robert S. Kerr Environmental Research Laboratory, Environmental Research Brief EPA/600/M-90/023, 12 p.

Radtke, D.B., 1990, Contaminant risks in the lower Colorado River valley, Arizona, California, and Nevada, in Minimizing Risk to the Hydrologic Environment: American Institute of Hydrology, 1990 Spring Meeting, Program with Abstracts, Las Vegas, Nevada, March 12-16, 1990, p. 23.

Radtke, D.B., and Kepner, W.G., 1990, Environmental contaminants in the Lower Colorado River valley, Arizona, California, and Nevada, in Water quality and quantity issues into the 1990s...Adaptation to current realities: Arizona Hydrological Society's 2nd Annual Symposium, Casa Grande, Arizona, September 14-16, 1989, Part R, Proceedings, p. 1-21.

Radtke, D.B., Kepner, W.G., and Effertz, R.J., 1988, Reconnaissance investigation of water quality, bottom sediment, and biota associated with irrigation drainage in the lower Colorado River valley, Arizona, California, and Nevada, 1986-87: U.S. Geological Survey Water-Resources Investigations Report 88-4002, 77 p.

Raymond, L.H., 1984, Overview of remote sensing for estimating consumptive use in the lower Colorado River flood plain, Arizona and California [abs.]: The Application of Remote Sensing to Agriculture, Casa Grande, Arizona, May 19, 1984, Proceedings, p. 23.

Raymond, L.H., and Owen-Joyce, S.J., 1986, Estimates of consumptive use and evapotranspiration in Palo Verde Valley, California, 1981 and 1983, in Johnson, A.I., and Rango, A., eds., Remote Sensing Applications for Consumptive Use (Evapotranspiration): American Water Resources Association Monograph Series 6, p. 25-34.

1987, Comparison of estimates of evapotranspiration and consumptive use in Palo Verde Valley, California: U.S. Geological Survey Water-Resources Investigations Report 87-4071, $27 \mathrm{p}$.

Raymond, L.H., Moran, M.S., and Jackson, R.D., 1987, Mapping latent heat energy from remotely sensed data and other variables using geographic-information system software, in Proceedings of the Conference on Spatial Data Systems for Management: Tucson, University of Arizona, November 5-6, 1987, p. 38-45.

1988, Mapping evapotranspiration using the energy-budget method with remotely sensed data: Symposium on Water-Use Data for Water Resources Management, American Water Resources Association, Tucson, Arizona, August 29-31, 1988, Proceedings, p. 655-665. 
Raymond, L.H., and Rezin, K.V., 1989, Evapotranspiration estimates using remote-sensing data, Parker and Palo Verde Valleys, Arizona and California: U.S. Geological Survey Water-Supply Paper 2334, 18 p.

Robertson, F.N., 1984, Isotopic content of ground water along the Colorado River in Arizona and California [abs.]: Geological Society of America Abstracts with Programs 1984, 97th Annual Meeting, Reno, Nevada, November 5-8, 1984, v. 16, no. 6, p. 636.

1984, Solubility controls of fluorine, barium and chromium in ground water in alluvial basins, in Hitchon, Brian, and Wallick, E.I., eds., Practical applications of ground water geochemistry, First Canadian/American Conference on Hydrogeology, Banff, Alberta, Canada, June 22-26, 1984, Proceedings: Worthington, Ohio, National Water Well Association, p. 96-102.

1984, Trace elements in ground water in southern Arizona [abs.], in Replogle, J.A., and Renard, K.G., eds., Water today and tomorrow: Specialty Conference, Irrigation and Drainage Division of the American Society of Civil Engineers, Flagstaff, Arizona, July 24-26, 1984, Proceedings, p. 674.

1986, Occurrence and solubility controls of trace elements in ground water in alluvial basins of Arizona, in Anderson, T.W., and Johnson, A.I., eds., Regional Aquifer Systems of the United States, Southwest Alluvial Basins of Arizona: American Water Resources Association Monograph Series 7, p. 69-80.

1986, Origin and chemistry of ground water along the Colorado River in Arizona, Nevada, and California [abs.], in 30th Annual Meeting of the Arizona-Nevada Academy of Science, Glendale, Arizona, April 19, 1986: Arizona-Nevada Academy of Science, v. 21, p. 56.

1989, Arsenic in ground water under oxidizing conditions, southwest United States [abs.]: Programme of the Seventh Annual European Meeting, Society for Environmental Geochemistry and Health, University of London, England, April 11-14, 1989, p. 15.

1989, Arsenic in ground water under oxidizing conditions, southwest United States, in Environmental Geochemistry and Health, v. 11, no. 3/4, December 1989: Great Britain, Gem Publishing Company for Science and Technology Letters, p. 171-185,

1989, Ground-water geochemistry and information transfer in alluvial basins in Arizona [abs.]: 28th International Geological Congress, Washington, D.C., July 9-19, 1989, Abstracts, v. 2, p. 709-710.

1989, Prediction of water quality through geochemical modeling in undeveloped areas in the desert southwest [abs.], in Pederson, G.L., and Smith, M.M., compilers, U.S. Geological Survey Second National Symposium on Water Quality-Abstracts of the Technical Sessions, Orlando, Florida, November 12-17, 1989: U.S. Geological Survey Open-File Report 89-409, p. 77-78. 
1990, Carbon-14 age dating in southeastern Arizona-Isotope and chemical models for interpretation of hydrologic flow system [abs.]: Fourteenth International Radiocarbon Conference,Tucson, Arizona, May 20-24, 1991, p. 236.

1990, Ground-water geochemistry and information transfer in alluvial basins in Arizona, in Simpson, E.S., and Sharp, J.M., eds., Selected Papers on Hydrogeology: International Association of Hydrogeologists, Proceedings of the 28th International Geological Congress, July 9-19, 1989, v. 1, p. 223-236.

1990, Trace constituents in ground water in alluvial basins in Arizona-Source, controls, and prediction [abs.]: Reading, England, Society for Environmental Geochemistry and Health Programme of the Eighth Annual European Meeting, April 1-4, 1990, p. 15.

1991, Geochemistry of ground water in alluvial basins of Arizona and adjacent parts of Nevada, New Mexico, and California: U.S. Geological Survey Professional Paper 1406-C, $90 \mathrm{p}$.

1991, Radiocarbon dating in the San Pedro Valley, southeastern Arizona [abs.]: Radiocarbon, v. 33, no. 2, p. 236.

Robertson, F.N., and Garrett, W.B., 1988, Distribution of fluoride in ground water in the alluvial basins of Arizona and adjacent parts of California, Nevada, and New Mexico: U.S. Geological Survey Hydrologic Investigations Atlas HA-665, 3 sheets.

Rogers, G.F., Malde, H.E., and Turner, R.M., 1984, Bibliography of repeat photography for evaluating landscape change: Salt Lake City, University of Utah Press, $179 \mathrm{p}$.

Roeske, R.H., Garrett, J.M., and Eychaner, J.H., 1989, Floods of October 1983 in southeastern Arizona: U.S. Geological Survey Water-Resources Investigations Report 85-4225-C, $77 \mathrm{p}$.

Schmidt, J.C., 1986, Changes in alluvial deposits, upper Grand Canyon: Fourth Federal Interagency Sedimentation Conference, v. 1, Las Vegas, Nevada, March 24-27, 1986, Proceedings, p. 2-48 to 2-57.

1986, Controls on flow separation and sedimentation in a bedrock river, Colorado River, Grand Canyon, Arizona: Geological Society of America, Abstracts with Programs, v. 18 , no. 5 , p. 741 .

1986, Location and characteristics of alluvial deposits, Colorado River, Grand Canyon, Arizona, in Geological Society of America, Abstracts with Programs, Annual Meeting, Flagstaff, Arizona, April 30-May 2, 1986, v. 18, no. 5, p. 410.

Schmidt, J.C., and Graf, J.B., 1987, Response of eddy-system deposits to dam operations, Colorado River, Grand Canyon National Park, Arizona [abs.]: Eos Transactions, American Geophysical Union, v. 67, no. 44, November 4, 1986, No. H41A-05, p. 950. 
1988, Aggradation and degradation of alluvial sand deposits, 1965 to 1986, Colorado River, Grand Canyon National Park, Arizona-Executive summary: U.S. Geological Survey Open-File Report 87-561, 15 p.

1990, Aggradation and degradation of alluvial sand deposits, 1965 to 1986, Colorado River, Grand Canyon National Park, Arizona: U.S. Geological Survey Professional Paper 1493, 74 p.

Schumann, H.H., 1986, Ground-water depletion and land subsidence in western Pinal County, Arizona, in Conference on Southwestern Ground Water Issues, Tempe, Arizona, October 20-22, 1986, Proceedings: National Water Well Association, p. 533-552.

1988, U.S. Geological Survey ground-water studies in Arizona: U.S. Geological Survey Open-File Report 88-164, Water Fact Sheet, 1 sheet.

Schumann, H.H., and Anderson, S.R., 1989, Land-subsidence measurements and aquifer-compaction monitoring in Tucson basin and Avra Valley, Arizona: U.S. Geological Survey Water-Resources Investigations Report 88-4167, 15 p.

Schumann, H.H., and Genualdi, R.B., 1986, Land subsidence, earth fissures, and water-level change in southern Arizona: Arizona Bureau of Geology and Mineral Technology, Geological Survey Branch, Map 23, scale 1:1,000,000, 1 sheet.

Schumann, H.H., Cripe, L.S., and Laney, R.L., 1986, Land subsidence and earth fissures caused by ground-water depletion in southern Arizona, U.S.A., in Land Subsidence: Third International Symposium on Land Subsidence, Venice, Italy, March 19-25, 1984, Proceedings, p. 841-851.

Schumann, H.H., Laney, R.L., and Cripe, L.S., 1986, Land subsidence and earth fissures caused by ground-water depletion in southern Arizona, in Anderson, T.W., and Johnson, A.I., eds., Regional Aquifer Systems of the United States, Southwest Alluvial Basins of Arizona: American Water Resources Association Monograph Series 7, p. 81-91.

Schumann, H.H., and Littin, G.R., 1985, Land subsidence and earth fissures in southern Pinal County, Arizona [abs.]: Eos Transactions, American Geophysical Union, v. 66, no. 46, November 12, 1985, p. 851.

Schumann, H.H., Littin, G.R., and Wallace, B.L., 1983, Monitoring water-level change, aquifer compaction, and land subsidence along the Salt-Gila aqueduct in south-central Arizona [abs.], in Land Subsidence-Design and Solutions: The Arizona Consulting Engineers Association, Second Arizona Symposium on Subsidence, Phoenix, Arizona, October 21, 1983, p. 14.

Schumann, H.H., and Tosline, D.J., 1983, Occurrence and prediction of earth-fissure hazards caused by ground-water depletion in south-central Pinal County, Arizona [abs.], in Land Subsidence-Design and Solutions: The Arizona Consulting Engineers Association, Second Arizona Symposium on Subsidence, Phoenix, Arizona, October 21, 1983, p. 2. 
Schumann, H.H., Tosline, D.J., and Wrege, B.M., 1984, Occurrence and prediction of earthfissure hazards caused by ground-water depletion in south-central Arizona, U.S.A. [abs.], in Replogle, J.A., and Renard, K.G., eds., Water today and tomorrow: Specialty Conference, Irrigation and Drainage Division of the American Society of Civil Engineers, Flagstaff, Arizona, July 24-26, 1984, Proceedings, p. 673.

Smith, C.F., and Garrett, J.M., 1991, Compilation of flood data for Maricopa County, Arizona, through September 1989: Phoenix, Arizona, Flood Control District of Maricopa County report, $250 \mathrm{p}$.

Stollenwerk, K.G., and Eychaner, J.H., 1987, Acidic ground-water contamination from copper mining near Globe, Arizona-Proceedings of the Third Technical Meeting, Pensacola, Florida, March 23-27, 1987: U.S. Geological Survey Open-File Report 87-109, p. D-19 to D-24.

1989, Solubility of aluminum and iron in ground water near Globe, Arizona, in Mallard, G.E., and Ragone, S.E., eds., U.S. Geological Survey Toxic Substances Hydrology Program-Proceedings of the Technical Meeting, Phoenix, Arizona, September 26-30, 1988: U.S. Geological Survey Water-Resources Investigations Report 88-4220, p. 581-591.

Tasker, G.D., Eychaner, J.H., and Stedinger, J.R., 1986, Application of generalized least squares in regional hydrologic regression analysis, in Selected Papers in the Hydrologic Sciences, 1986: U.S. Geological Survey Water-Supply Paper 2310, p. 107-115.

Thompson, T.H., Nuter, Janet, and Anderson, T.W., 1984, Maps showing distribution of dissolved solids and dominant chemical type in ground water, Basin and Range Province, Arizona: U.S. Geological Survey Water-Resources Investigations Report 83-4114-C, 4 sheets.

Thomsen, B.W., and Baldys, Stanley, III, 1985, Ground-water conditions in and near the Gila River Indian Reservation, south-central Arizona: U.S. Geological Survey WaterResources Investigations Report 85-4073, 2 sheets.

Thomsen, B.W., and Eychaner, J.H., 1991, Predevelopment hydrology of the Gila River Indian Reservation, south-central Arizona: U.S. Geological Survey Water-Resources Investigations Report 89-4174, 44 p.

Thomsen, B.W., and Miller, B.H., 1991, Ground-water conditions in and near the Salt River Indian Reservation, south-central Arizona: U.S. Geological Survey Water-Resources Investigations Report 89-4176, 2 sheets.

Thomsen, B.W., and Porcello, J.J., 1991, Predevelopment hydrology of the Salt River Indian Reservation, East Salt River Valley, Arizona: U.S. Geological Survey Water-Resources Investigations Report 91-4132, 37 p.

Tucci, Patrick, 1984, Surface resistivity studies for water resources investigations, near Tucson, Arizona, in NWWA/EPA Conference on surface and borehole geophysical methods in 
ground water investigations, San Antonio, Texas, February 7-9, 1984: Worthington, Ohio, National Water Well Association, p. 92-106.

1989, Geophysical methods for water-resources studies in southern and central Arizona, in Proceedings of the Symposium on the Application of Geophysics to Engineering and Environmental Problems: Denver, Colorado, Society of Engineering and Mineral Exploration Geophysicists, p. 368-383.

Tucci, Patrick, and Pool, D.R., 1986, Use of geophysics for geohydrologic studies in the alluvial basins of Arizona, in Anderson, T.W., and Johnson, A.I., eds., Regional Aquifer Systems of the United States, Southwest Alluvial Basins of Arizona: American Water Resources Association Monograph Series 7, p. 37-56.

Tucci, Patrick, Schmoker, J.W., and Robbins, S.L., 1983, Density of basin-fill deposits calculated for borehole gravity data in four basins in central and southern Arizona: Society of Exploration Geophysicists Annual International Meeting, 53d, Las Vegas, Nevada, September 11-15, 1983, Technical Program, p. 28-31.

Turner, R.M., and Busman, C.L., 1984, Vegetative key for identification of the woody legumes of the Sonoran Desert region: Desert Plants, v. 6, no. 4, p. 189-202.

U.S. Geological Survey, 1983, Activities of the Water-Resources Division of the U.S. Geological Survey in Arizona-1983: U.S. Geological Survey duplicated report, $31 \mathrm{p}$.

1983, Water resources data for Arizona, water year 1981: U.S. Geological Survey Water-Data Report AZ-81-1, 532 p.

1984, Annual summary of ground-water conditions in Arizona, spring 1982 to spring 1983: U.S. Geological Survey Open-File Report 84-428, scale 1:125,000, 2 sheets.

1984, Arizona water issues, in National Water Summary 1983-Hydrologic events and issues: U.S. Geological Survey Water-Supply Paper 2250, p. 85-88.

1985, Annual summary of ground-water conditions in Arizona, spring 1983 to spring 1984: U.S. Geological Survey Open-File Report 85-410, scale 1:125,000, 2 sheets.

1986, Annual summary of ground-water conditions in Arizona, spring 1984 to spring 1985: U.S. Geological Survey Open-File Report 86-422W, 2 sheets.

Van Metre, P.C., 1988, A digital interface between a geographic-information system and the U.S. Geological Survey three-dimensional ground-water flow model [abs.]: Eos Transactions, American Geophysical Union, v. 69, no. 16, April 19, 1988, p. 347.

1990, Structure and application of an interface program between a geographic-information system and a ground-water flow model: U.S. Geological Survey Open-File Report 90-165, 68 p. 
1990, The impact of uranium in mine dewatering on dissolved gross-alpha and gross-beta activities in the Puerco River, Arizona and New Mexico, in Minimizing Risk to the Hydrologic Environment: American Institute of Hydrology, 1990 Spring Meeting, Program with Abstracts, Las Vegas, Nevada, March 12-16, 1990, p. 25.

Van Metre, P.C., Wirt, Laurie, and Gray, J.R., 1989, Geochemical controls on radionuclide mobility in shallow ground water near an ephemeral stream in northeastern Arizona [abs.], in Pederson, G.L., and Smith, M.M., compilers, U.S. Geological Survey Second National Symposium on Water Quality-Abstracts of the Technical Sessions, Orlando, Florida, November 12-17, 1989: U.S. Geological Survey Open-File Report 89-409, p. 103.

von Allworden, B.K., Owen-Joyce, S.J., Sandoval, J.D., and Raymond, L.H., 1991, Lower Colorado River Accounting System (LCRAS) Computer Program and Documentation: U.S. Geological Survey Open-File Report 91-179, 237 p.

Wallace, B.L., Wrege, B.M., and Schumann, H.H., 1986, Geohydrologic data along the Salt-Gila aqueduct of the Central Arizona Project in Maricopa and Pinal Counties, Arizona: U.S. Geological Survey Open-File Report 86-236, 49 p.

Wallin, R.W., Bassett, R.L., and Eychaner, J.H., 1991, Ground-water transport of polycyclic aromatic hydrocarbons in association with humic substances in the Pinal Creek basin, Globe, Arizona, in Mallard, G.E., and Aronson, D.A., eds., U.S. Geological Survey Toxic Substances Hydrology Program-Proceedings of the technical meeting, Monterey, California, March 11-15, 1991: U.S. Geological Survey Water-Resources Investigations Report 91-4034, p. 511-515.

Webb, R.H., 1984, Implications of the flood record to geomorphological research on the Colorado Plateau [abs.]: Geological Society of America Abstracts with Programs, 97th Annual Meeting, Reno, Nevada, v. 16, no. 6, p. 688.

1986, Spatial and temporal distribution of radiocarbon ages on rodent middens from the southwestern United States: Radiocarbon, v. 28, no. 1, p. 1-8.

1987, Debris flows from tributaries of the Colorado River, Grand Canyon National Park, Arizona-Executive summary: U.S. Geological Survey Open-File Report 87-117, $7 \mathrm{p}$.

1987, Occurrence of geomorphic effects of streamflow and debris flow floods in northern Arizona and southern Utah, in Mayer, L., and Nash, D., Catastrophic Flooding, v. 18: Boston, Allen \& Unwin, Inc., p. 247-265.

1987, Preliminary assessment of water quality in the alluvial aquifer of the Puerco River basin, northeastern Arizona: U.S. Geological Survey Water-Resources Investigations Report 87-4126, $70 \mathrm{p}$.

1988, Vegetation assemblage and soil chemical differences among four alluvial surfaces in Gold Valley, Death Valley National Monument, California: Ecological Society of America Bulletin, v. 69, no. 2, p. 335. 
Webb, R.H., and Baker, V.R., 1986, Floods and channel change in southern Utah [abs.], in Geological Society of America, Abstracts with Programs, Annual Meeting, Flagstaff, Arizona, April 30-May 2, 1986, v. 18, no. 5, p. 421.

1987, Changes in hydrologic conditions related to large floods on the Escalante River, south-central Utah: Regional Flood Frequency Analysis, p. 309-323.

Webb, R.H., and Bentancourt, J.L., 1988, Changes in variability and seasonality of flooding in southern Arizona related to general circulation and oceanic fluctuations [abs.]: Eos Transactions, American Geophysical Union, v. 69, no. 44, November 1988, p. 1220.

1990, Climatic effects on flood frequency-An example from southern Arizona, in Bentancourt, J.L., and MacKay, A.N., eds. Proceedings of the 6th Annual Pacific Climate (PACLIM) Workshop, March 5-8, 1989: Sacramento, California Department of Water Resources Interagency Ecological Studies Program Technical Report 23, p. 61-66.

in press, Climatic variability and flood frequency of the Santa Cruz River, Pima County, Arizona: U.S. Geological Survey Water-Supply Paper 2379, 40 p.

Webb, R.H., O'Connor, J.E., and Baker, V.R., 1988, Paleohydrologic reconstruction of flood frequency on the Escalante River, south-central Utah, in Baker, V.R., Kochel, R.C., and Patton, P.C., eds., Flood geomorphology: New York, John Wiley, p. 403-418.

Webb, R.H., Pringle, P.T., Reneau, S.L., and Rink, G.R., 1988, Monument Creek debris flow, 1984 - Implications for formation of rapids on the Colorado River in Grand Canyon National Park: Geology, v. 16, no. 1, p. 50-54.

Webb, R.H., Pringle, P.T., and Rink, G.R., 1989, Debris flows from tributaries of the Colorado River, Grand Canyon National Park, Arizona: U.S. Geological Survey Professional Paper $1492,39 \mathrm{p}$.

Webb, R.H., and Rathburn, S.L., 1988, Paleoflood hydrologic research in the southwestern United States, in Arid Lands-Hydrology, scour, and water quality: Washington, D.C., National Research Council, Transportation Research Board, Record 1201, p. 9-21.

Webb, R.H., Rink, G.R., and Favor, B.O., 1987, Distribution of radionuclide and trace elements in ground water, grasses, and surficial sediments associated with the alluvial aquifer along the Puerco River, northeastern Arizona-A reconnaissance sampling program: U.S. Geological Survey Open-File Report 87-206, 108 p.

Webb, R.H., Rink, G.R., and Radtke, D.B., 1987, Preliminary assessment of water quality in the alluvial aquifer of the Puerco River basin, northeastern Arizona: U.S. Geological Survey Water-Resources Investigations Report 87-4126, $70 \mathrm{p}$.

Webb, R.H., Steiger, J.W., and Newman, E.B., 1988, The response of vegetation to disturbance in Death Valley National Monument, California: U.S. Geological Survey Bulletin 1793, $103 \mathrm{p}$. 
Webb, R.H., Steiger, J.W., and Turner, R.M., 1987, Dynamics of Mojave Desert shrub assemblages in the Panamit Mountains, California: Ecology, v. 68, no. 3, p. 478-490.

Webb, R.H., Steiger, J.W., and Wilshire, H.G., 1986, Recovery of compacted soils in Mojave Desert ghost towns: Soil Science Society of America Journal, v. 50, no. 5, September-October 1986, p. 1341-1344.

Webb, R.H., and Wilshire, H.G., eds., 1983, Environmental effects of off-road vehicles-Impacts and management in arid regions: New York, Springer-Verlag, 534 p.

Werley, M.R., 1990, A program to digitize charts having nonstandard coordinate systems [abs.], in Balthrop, B.H., and Baker, E.G., compilers, 1990, U.S. Geological Survey, National Computer Technology Meeting, Program and Abstracts, San Antonio, Texas, May 7-11, 1990: U.S. Geological Survey Open-File Report 90-161, p. 49.

White, N.D., and Anderson, T.W., 1985, Arizona ground-water resources, in National Water Summary 1984, Hydrologic Events, Selected Water-Quality Trends, and Ground-Water Resources: U.S. Geological Survey Water-Supply Paper 2275, p. 135-140.

White, N.D., and Fields, R.L., 1984, Bibliography of water-resources reports for Arizona through 1982: U.S. Geological Survey special report, 152 p.

White, N.D., and Garrett, W.B., 1984, Water resources data for Arizona, water year 1982: U.S. Geological Survey Water-Data Report AZ-82-1, 440 p.

1986, Water resources data for Arizona, water year 1983: U.S. Geological Survey Water-Data Report AZ-83-1, 387 p.

1987, Water resources data for Arizona, water year 1984: U.S. Geological Survey Water-Data Report AZ-84-1, 381 p.

1988, Water resources data for Arizona, water year 1985: U.S. Geological Survey Water-Data Report AZ-85-1, 343 p.

Wilson, R.P., 1986, Sonar patterns of Colorado River bed, Grand Canyon: Fourth Federal Interagency Sedimentation Conference, v. 2, Las Vegas, Nevada, March 24-27, 1986, Proceedings, p. 5-133 to 5-142.

1988, Water resources in the northern part of the Agua Fria area: Arizona Department of Water Resources Bulletin 5, $109 \mathrm{p}$.

1990, Arizona water supply and use, in Carr, J.E., Chase, E.B., Paulson, R.W., and Moody, D.W., compilers, National Water Summary 1987-Hydrologic Events and Water Supply and Use: U.S. Geological Survey Water-Supply Paper 2350, p. 157-164.

1991, The regulatory surface-A proposed method of identifying wells that yield Colorado River water [abs.]: Bethesda, Maryland, American Water Resources Association, 27th Annual Conference Water Management of River Systems and 
Symposium Resource Development of the Lower Mississippi River, New Orleans, Louisiana, September 8-13, 1991, p. 359-360.

Wilson, R.P., and Garrett, W.B., 1988, Water resources data for Arizona, water year 1986: U.S. Geological Survey Water-Data Report AZ-86-1, 341 p.

1989, Water resources data for Arizona, water year 1987: U.S. Geological Survey Water-Data Report AZ-87-1, 385 p.

Wirt, Laurie, Gray, J.R., and Van Metre, P.C., 1989, Occurrence and movement of radionuclides in the Puerco River basin, Arizona and New Mexico [abs.], in Pederson, G.L., and Smith, M.M., compilers, U.S. Geological Survey Second National Symposium on Water Quality-Abstracts of the Technical Sessions, Orlando, Florida, November 12-17, 1989: U.S. Geological Survey Open-File Report 89-409, p. 109.

Wirt, Laurie, Van Metre, P.C., and Favor, Barbara, 1991, Historical water-quality data, Puerco River basin, Arizona and New Mexico: U.S. Geological Survey Open-File Report 91-196, $339 \mathrm{p}$.

Wrege, B.M., 1986, Earth fissure prediction by seismic surface-wave attenuation [abs.], in 30th Annual Meeting of the Arizona-Nevada Academy of Science, Glendale, Arizona, April 19, 1986: Arizona-Nevada Academy of Science, v. 21, p. 50-51.

1986, Surface- and borehole-geophysical surveys used to define hydrogeologic units in south-central Arizona, in Conference on Southwestern Ground Water Issues, Tempe, Arizona, October 20-22, 1986, Proceedings: National Water Well Association, p. 485-499.

1988, Abatement of high arsenic levels in water-supply wells, southern Apache County, Arizona [abs.]: Eos Transactions, American Geophysical Union, v. 69, no. 16, April 19, 1988, p. 367.

Wrege, B.M., Hasbrouck, W.P., and Schumann, H.H., 1985, Seismic surface-wave attenuation across earth fissures in the alluvium, south-central Arizona, in NWWA Conference on Surface and Borehole Geophysical Methods in Ground Water Investigations, Fort Worth, Texas, February 12-14, 1985: Worthington, Ohio, National Water Well Association, p. 121-131.

Wrege, B.M., Schumann, H.H., and Wallace, B.L., 1985, Geohydrologic data along the Tucson aqueduct of the Central Arizona Project in Pinal and Pima Counties, Arizona: U.S. Geological Survey Open-File Report 85-565, 77 p.

Zimmerman, D.A., Hanson, R.T., and Davis, P.A., 1991, A comparison of parameter estimation and sensitivity analysis techniques and their impact on the uncertainty in ground water flow model predictions: U.S. Nuclear Regulatory Commission NUREG/CR-5522 (Sandia National Laboratories SAND90-0128), 197 p. 


\section{SOURCES OF PUBLICATIONS AND INFORMATION}

Many U.S. Geological Survey products and information are available as over-the-counter sales from Earth Science Information Centers across the Nation. Included among these are:

- U.S. Geological Survey, Earth Science Information Center, Room 101, 4230 University Drive, Anchorage, AK 99508-4664; telephone (907) 786-7011;

- U.S. Geological Survey, Earth Science Information Center, Box 25046, Building 25, Room 1813, Denver Federal Center, MS504, Denver, CO 80225-0046; telephone (303) 236-5829;

- U.S. Geological Survey, Earth Science Information Center, Building 3, Room 3128, 345 Middlefield Rd., Menlo Park, CA 94025; telephone (415) 329-4309 or -4390;

- U.S. Geological Survey, Earth Science Information Center, Room 8105, Federal Building, 125 South State Street, Salt Lake City, UT 84138-1177; telephone (801) 524-5652; and

- U.S. Geological Survey, Earth Science Information Center, U.S. Post Office Building, Room 135, West 904 Riverside Avenue, Spokane, WA (509) 353-2524.

Most book reports (Professional Papers, Water-Supply Papers, Bulletins, Circulars, WaterResources Investigations Reports, and Open-File Reports) may be ordered from:

- U.S. Geological Survey, Earth Science Information Center, Open-File Reports Section, Box 25286, MS517, Denver Federal Center, Denver, CO 80225-0286; telephone (303) 236-7476.

Hydrologic Investigations Atlases, Hydrologic Unit Maps, topographic maps, and other maps pertaining to Arizona are available from:

- U.S. Geological Survey, Map Distribution, Box 25286, Denver Federal Center, Building 810, Denver, CO 80225-0286; telephone (303) 236-7477.

Circular 900, titled "Guide to Obtaining U.S. Geological Survey Information," is a free publication designed to help the public utilize U.S. Geological Survey resources. A copy of Circular 900 may be obtained at the Earth Science Information Centers listed above or ordered from the Earth Science Information Center, Open-File Reports Section (which also is listed above).

Certain reports-those reports having an alpha-numeric designation such as "PB-89 167399 " at the end of the citation, annual U.S. Geological Survey Water-Data Reports (which contain all data collected and stored in the U.S. Geological Survey National Water Data Storage and Retrieval System, by state), and most Water-Resources Investigations Reports released before 1982-are available from: 
- National Technical Information Service, U.S. Department of Commerce, 5285 Port Royal Road, Springfield, VA 22161; telephone (703) 487-4650.

The National Water Data Exchange (NAWDEX) was established to assist users of water data in identifying, locating, and acquiring needed data. NAWDEX maintains two data bases: a WaterData Sources Directory and a Master Water-Data Index that identifies and describes water data. These are available from:

- U.S. Geological Survey, National Water Data Exchange, 421 National Center, Reston, VA 22092; telephone (703) 648-6848.

New reports are announced monthly in "New Publications of the Geological Survey," subscriptions to which are available upon request from:

- U.S. Geological Survey New Publications, 582 National Center, Reston, VA 22092.

Topographic, orthophotoquad, land-use, and land-cover maps, and geographic-name and geodesic-control lists pertaining to Arizona are available from:

- U.S. Geological Survey, Earth Science Information Center, Building 3, Room 3128, 345 Middlefield Rd., Menlo Park, CA 94025; telephone (415) 329-4309 or -4390.

Reports and maps produced by the Arizona District are available for inspection in the Tucson office:

- U.S. Geological Survey, Water Resources Division, 375 South Euclid Avenue, Tucson, AZ 85719; telephone (602) 670-6671 or -6201 . 